\title{
WestVirginiaUniversity
}

THE RESEARCH REPOSITORY @ WVU

Graduate Theses, Dissertations, and Problem Reports

2013

\section{Entrepreneurship, Institutions, and the Informal Economy}

Travis C. Wiseman

West Virginia University

Follow this and additional works at: https://researchrepository.wvu.edu/etd

\section{Recommended Citation}

Wiseman, Travis C., "Entrepreneurship, Institutions, and the Informal Economy" (2013). Graduate Theses, Dissertations, and Problem Reports. 171.

https://researchrepository.wvu.edu/etd/171

This Dissertation is protected by copyright and/or related rights. It has been brought to you by the The Research Repository @ WVU with permission from the rights-holder(s). You are free to use this Dissertation in any way that is permitted by the copyright and related rights legislation that applies to your use. For other uses you must obtain permission from the rights-holder(s) directly, unless additional rights are indicated by a Creative Commons license in the record and/ or on the work itself. This Dissertation has been accepted for inclusion in WVU Graduate Theses, Dissertations, and Problem Reports collection by an authorized administrator of The Research Repository @ WVU.

For more information, please contact researchrepository@mail.wvu.edu. 


\title{
Entrepreneurship, Institutions, and the Informal Economy
}

\author{
Travis C. Wiseman \\ Dissertation submitted to the \\ College of Business and Economics \\ at West Virginia University in partial \\ fulfillment of the requirements for the degree of
}

Doctor of Philosophy

in

Economics
Andrew T. Young, Ph.D., Chair
Roger Congleton, Ph.D.
Brian Cushing, Ph.D.
Russell Sobel, Ph.D.
William Trumbull, Ph.D.
Department of Economics
Morgantown, West Virginia
2013

Keywords: corruption, institutional quality, latent variable, MIMIC model, productive entrepreneurship, regulation, religion, rent-seeking, shadow economy, tax burden, unproductive entrepreneurship, U.S. states 


\section{Abstract \\ Entrepreneurship, Institutions, and the Informal Economy \\ Travis C. Wiseman}

This dissertation comprises three essays which investigate the empirical relationships between institutions (formal and informal), entrepreneurial outcomes (productive and unproductive), and shadow economy size at the U.S. state-level. Chapter 1 opens with some discussion of the topics explored here and provides an overview of important results from each of the essays. In Chapter 2, the first of the empirical essays, I focus on U.S. shadow economies, providing estimates of shadow economy size for 50 U.S. states over the period 1997 to 2008 as a foundation for analysis in the subsequent chapter. Chapter 3 focuses on the relationship between entrepreneurship, shadow economy size, and corruption at the U.S. state-level. Specifically, I question the importance of the entrepreneur's choice (for which estimates of shadow economy size serve as a proxy) to participate in the formal or informal economy as a channel through which public official corruption affects observed (formal sector) entrepreneurial outcomes. Chapter 4 is a joint effort with Andrew Young. In this essay we revisit Baumol's (1990) conjectures on the role of institutions in determining whether entrepreneurs will channel their efforts towards wealth-generating activities or toward zero- or negative-sum rent-seeking, using cross-section data on informal, religious institutions. Chapter 5 summarizes the conclusions of the aforementioned chapters and discusses some possibilities for further investigation. 


\title{
Dedication
}

\author{
Teresa Wiseman \\ Barbara Mann \\ Casey Yanero
}

In memory of

Thomas H. Wiseman Jr.

Elizabeth Sites

Howard Sites

Charles H. Wiseman 


\section{Acknowledgements}

First, I would like to thank my partner, Casey Yanero, for her love, guidance and support. The doctoral process was no easier on her than me; her patience and tolerance played no small part in my successful completion of this degree. I love you Casey.

I would also like to thank my dissertation chair, Andrew Young, for his guidance over the past four years. Andy's motivation in academia is second to none, and he has proven a most valuable colleague and friend.

Thanks to the remaining members of my dissertation committee: Roger Congleton, Brian Cushing, Russell Sobel, and William Trumbull. Each of them has been kind enough to provide feedback on my work and progress in the program over the years. I am especially thankful for their insights that assisted in the completion of this dissertation.

Also, thanks to my close friends and family for their patience and understanding; especially those to whom this dissertation is dedicated. The doctoral process put large constraints on my time, and I feel at times that I failed to maintain our relationships as I would like. It is your love and support that motivated me most. I love each of you.

Finally, I would like to thank the Charles G. Koch Foundation, the Marcus Foundation, Inc. and the Institute for Humane Studies, Ken and Randy Kendrick, and the European Social Fund for their generous financial support throughout my graduate study. 


\section{Table of Contents}

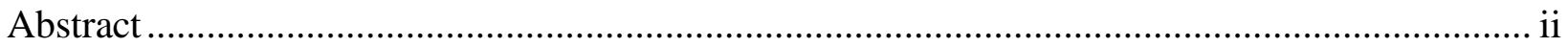

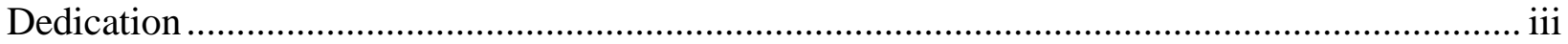

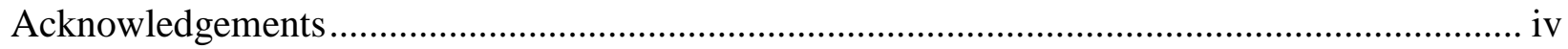

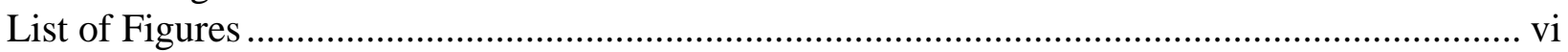

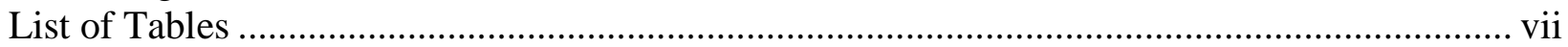

\section{Chapter 1}

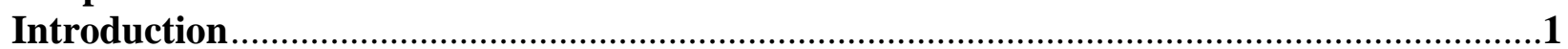

\section{Chapter 2}

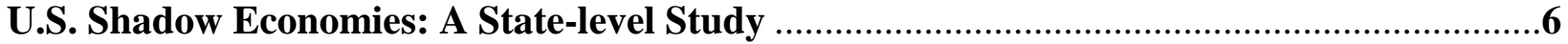

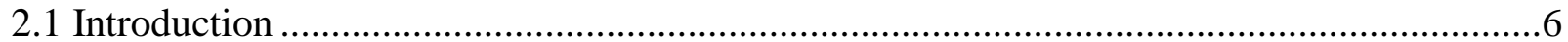

2.2 Theory and Measurement of Shadow Economies ........................................................ 10

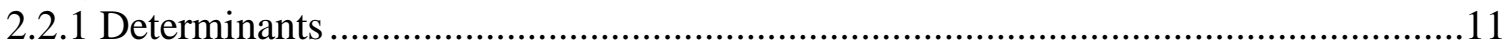

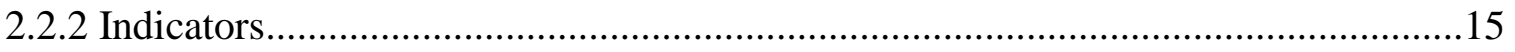

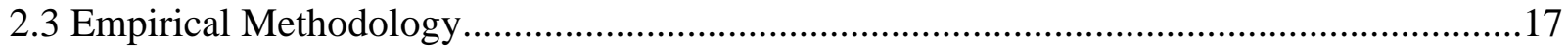

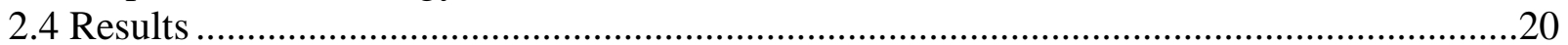

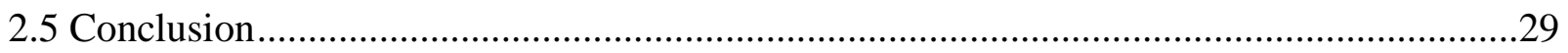

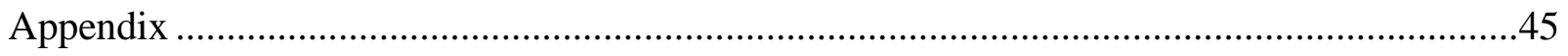

\section{Chapter 3}

Entrepreneurship, Corruption, and the Size of U.S. Underground Economies ..................46

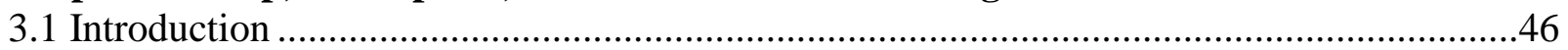

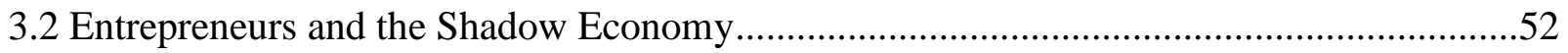

3.3 Measuring Corruption, Shadow Economy Size, and Entrepreneurship ...........................56

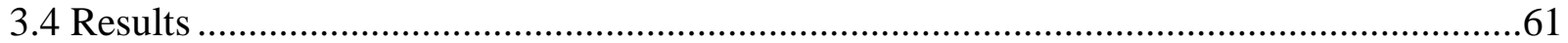

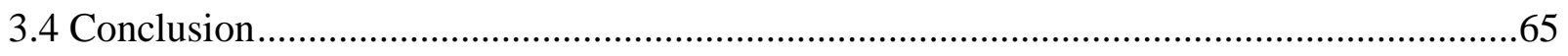

\section{Chapter 4}

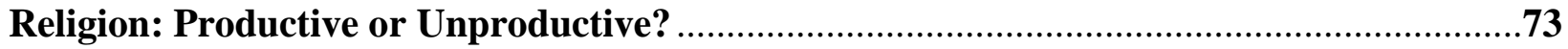

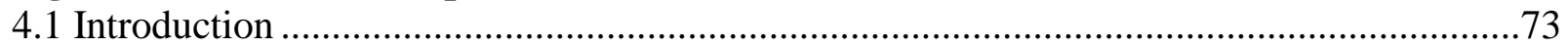

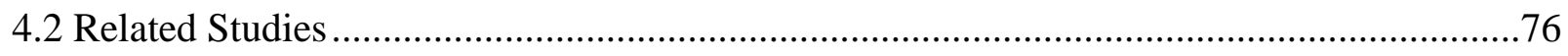

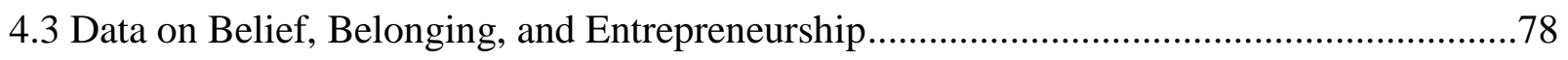

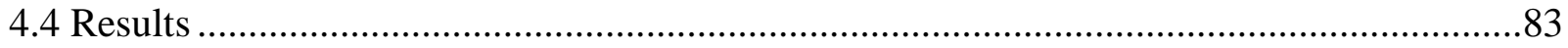

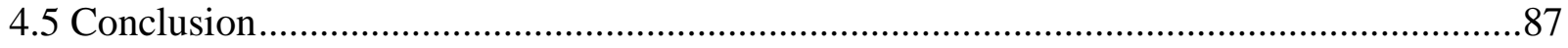

\section{Chapter 5}

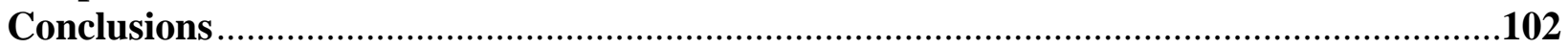

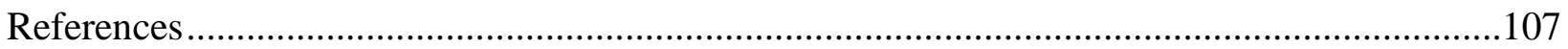

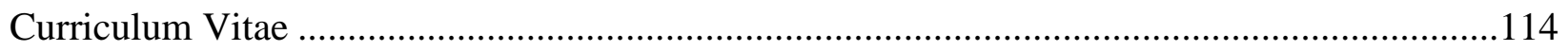




\section{List of Figures}

\section{Chapter 2}

\section{U.S. Shadow Economies: A State-level Study}

Figure 2.1 Relationships between Indirect Tax (\% GDP) and Indicator Variables........................31

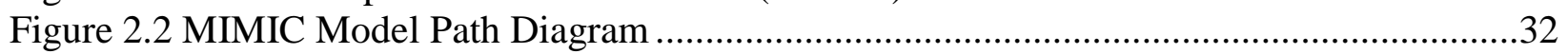

Figure 2.3 Real GDP Per Capita against Shadow Economy Size................................................33

Figure 2.4 Real GDP against Shadow Economy Size ..............................................................33

Figure 2.5 Shadow Economy Value Per Capita against Shadow Economy Size ...........................34

Figure 2.6 Percent of Population with a Bachelor's Degree or Higher against Institutional Quality ...............................................................................................34

Figure 2.7 Percent of Population with a Bachelor's Degree of Higher against Shadow Economy Size

\section{Chapter 3}

Entrepreneurship, Corruption, and the Size of U.S. Underground Economies

Figure 3.1 Relationships between Entrepreneurship Scores and Shadow Economy Size..... .67

Figure 3.2 Relationships between Entrepreneurship Scores and Public Official Corruption.........68

Figure 3.3 Relationship between Shadow Economy Size and Public Official Corruption ...........69

\section{Chapter 4}

Religion: Productive or Unproductive?

Figure 4.1 Relationships between Entrepreneurship Scores and Worship Service Attendance ....90

Figure 4.2 Relationships between Entrepreneurship Scores and Belief in God ...........................91

Figure 4.3 Relationships between Entrepreneurship Scores and Frequency of Prayer ................92

Figure 4.4 Relationships between Entrepreneurship Scores and Importance of Religion ............93 


\section{List of Tables}

\section{Chapter 2}

U.S. Shadow Economies: A State-level Study

Table 2.1 Variables, Descriptions, and Sources

Table 2.2 MIMIC Model Regression Results ..........................................................................

Table 2.3 U.S. State-level Shadow Economy Estimates (\% GDP), 1997-2008,

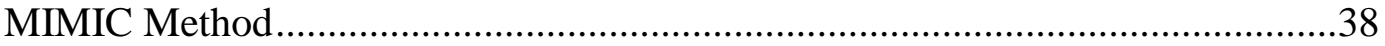

Table 2.4 U.S. State-level Rank by GDP Per Capita ..................................................................

Table 2.5 U.S. State-level Shadow Economy Estimates (\% GDP), 1997-2008, Electricity Consumption Method ........................................................................42

Table 2.6 Example of Electricity Consumption Method Calculation.............................................44

\section{Chapter 3}

Entrepreneurship, Corruption, and the Size of U.S. Underground Economies

Table 3.1 Summary Statistics ……………………….........................................................

Table 3.2 Regressions of Productive, Unproductive, and Net Entrepreneurship ..........................71

Table 3.3 Regressions of Productive, Unproductive, and Net Entrepreneurship with

Corruption IV

\section{Chapter 4}

Religion: Productive or Unproductive?

Table 4.1 Data Description and Sources for Variables Used in the Construction of Entrepreneurship Scores

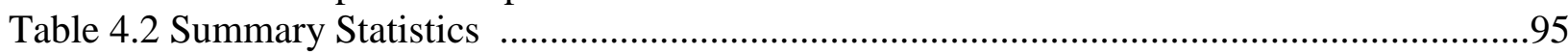

Table 4.3 Regressions of Productive Entrepreneurship Scores .................................................96

Table 4.4 Regressions of Unproductive Entrepreneurship Scores ............................................97

Table 4.5 Regressions of Net Entrepreneurial Productivity Scores .............................................98

Table 4.6 Correlation Matrix of Religion Variables ..................................................................99

Table 4.7 Regressions of Net, Productive, and Unproductive Entrepreneurship Scores

Including All Previously Significant Religion Variables 100

Table 4.8 Regressions of Productive Entrepreneurship Scores, Controlling for Total Adherents. 


\section{Chapter 1}

\section{Introduction}

"[T] he function of entrepreneurs is to reform or revolutionize the pattern of production by exploiting an invention or, more generally, an untried technological possibility for producing a new commodity or producing an old one in a new way, by opening up a new source of supply of materials or a new outlet for products, by reorganizing an industry and so on."

\section{Joseph A. Schumpeter - Capitalism, Socialism, and Democracy, Chapter XII}

The Schumpeterian impression of the entrepreneur's role in society, while certainly not the only impression, forms the basis for the empirical analyses found in the following chapters. It is Schumpeter's (1912 [1934]) theory of the entrepreneur as the individual in society responsible for "the carrying out of new combinations" - or "creative destruction" - that prompted William Baumol in 1990 to re-examine the role of the entrepreneur in society. Baumol (1990, p. 897-898) asked of Schumpeter's entrepreneur:

If entrepreneurs are defined, simply, to be persons who are ingenious and creative in finding ways that add to their own wealth, power, and prestige, then is it not to be expected that not all of them will be overly concerned with whether an activity that achieves these goals adds much or little to the social product or, for that matter, even whether it is an actual impediment to production. 
In other words, Baumol's primary concern is that, by Schumpeter's definition, the entrepreneur may very well carry out "new combinations" that result in plain destruction. Schumpeter's theoretical shortcoming is nowhere more evident than in his own assertion that "[e]ntrepreneurial profit is the expression of the value of what the entrepreneur contributes to production" (Schumpeter, 1912 [1934]).

Baumol's (1990) extension of the Schumpeterian framework is a powerful theoretical contribution. Under the amended framework, Schumpeter's entrepreneurs behave in much the same way, except that allocation of their entrepreneurial resources becomes dependent upon institutions. That is, entrepreneurs will, according to Baumol, channel their resources into either productive or unproductive activities depending on which activities the institutional framework in their local economy make most rewarding. In short, productive entrepreneurs are those whose activities expand the size of the economic pie; unproductive entrepreneurs are those who seek to either lawfully or unlawfully redistribute it (Baumol, 2007).

In the chapters that follow, Baumol's hypothesis is examined in new light using U.S. state-level data. To date, much empirical study of the relationships between institutions and entrepreneurial outcomes has focused on formal settings, in terms of both institutions and market activity. Here, I investigate ways in which Baumolian entrepreneurs interact with both informal markets and informal institutions.

Informal markets (or shadow economies) are markets where participants engage in trade, undertaken in a way that deliberately conceals their actions from detection by public authorities. Absent from either Schumpeter's or Baumol's analysis is detailed discussion of productive or unproductive activities taking place in such markets. Investigating these relationships, however, 
is no easy task. Shadow economic activity, by definition, is unobserved. In order to take a closer look at these relationships, one must first measure U.S. shadow economies.

Chapter 2 focuses on estimating shadow economy size. I do so using a unique system of equations, known as the MIMIC model, that relates both potential causes of shadow economic activity, and potential indicators of the occurrence of shadow economic activity to a measure of the shadow economy's size, in terms of state-level GDP. Recent studies of shadow economies focus primarily on cross-country comparisons. Few examine regional or state-level variations in underground economic activity. In Chapter 2, I present estimates of the shadow economy for 50 U.S. states over the period 1997 to 2008. Results suggest that size of government; tax and social welfare burdens; labor market regulations; and intensity of regulation enforcement are important determinants of the underground economy. Among the states, Delaware, on average, maintains the smallest shadow economy at $7.28 \%$ of GDP; Oregon, on average, has the second smallest shadow economy at $7.41 \%$ of GDP; followed by Colorado, averaging $7.52 \%$ of GDP, and rounding out the three smallest shadow economies in the U.S. West Virginia and Mississippi, on average, have the largest shadow economies in the U.S. as a percent of GDP $(9.32 \%$ and $9.54 \%$, respectively).

With shadow economy estimates in hand, I return to Baumol's hypothesis. Chapter 3 explores the relationship between entrepreneurship, shadow economy size, and corruption using U.S. state-level productive and unproductive entrepreneurship scores provided by Sobel (2008) and Wiseman and Young (2012); state-level shadow economy estimates from Wiseman (2012); and per capita measures of state-level public official corruption. I examine whether formal sector productive (unproductive) entrepreneurial activity is associated with lower (higher) levels of informal economic activity. Additionally, I investigate the importance of the shadow economy as 
a potential channel through which formal sector entrepreneurs respond to corrupt public officials. Using OLS and GMM estimation, I aim to fill a gap between several related literatures by asking whether corruption affects entrepreneurial outcomes primarily through its effects on the shadow economy. I contend that if this is the case, then estimates of corruption should serve as a good instrument for shadow economy size in an entrepreneurial outcome regression.

Results suggest that shadow economy size correlates robustly, negatively (positively) and in a statistically significant way with productive (unproductive) entrepreneurship. Additionally, I present evidence that public official corruption is a strong instrument for shadow economy size; one for which validity cannot be rejected in regressions on productive, unproductive, and net entrepreneurship scores.

In a joint effort with Andrew Young, Chapter 4 looks closely at entrepreneurship and informal institutions. Informal institutions are "rules of the game" such as cultural customs, traditions, and codes of conduct that guide (or constrain) human interaction (North, 1991). Specifically, we explore the relationships between measures of religiosity and levels of entrepreneurial activity, both productive and unproductive, using cross-section U.S. state level data. In doing so, we re-visit Baumol's (1990) conjectures on the role of institutions in determining whether entrepreneurs will channel their efforts towards wealth-generating activities or towards zero- or negative-sum rent-seeking. Measures of both belief (e.g., the frequency of prayer) and belonging (e.g., church attendance) that has been stressed by authors such as Barro and McCleary (2003) are closely considered. Results suggest that several religious variables significantly and negatively correlate with a state's productive entrepreneurship score. Alternatively, most religious variables in the data do not correlate significantly with unproductive entrepreneurship. (An exception is the total number of Christian adherents as a 
percentage of the population.) Findings also suggest that the percent of individuals reporting as atheist/agnostic is positively associated with productive entrepreneurship.

Chapter 5 concludes this dissertation with a summary of Chapters 2 through 4 , and some discussion about future research possibilities with a focus on entrepreneurship, institutions, and informal economies. 


\section{Chapter 2}

\section{U.S. Shadow Economies: A State-level Study}

"[S] muggler; a person who, though no doubt highly blameable for violating the laws of his country, is frequently incapable of violating those of natural justice, and would have been, in every respect, an excellent citizen, had not the laws of his country made that a crime which nature never meant to be so."

Adam Smith - The Wealth of Nations, Book V, Chapter II, Part II, Article IV

\subsection{Introduction}

World-wide, shadow economies have been the focus of much attention in recent years, and for good reason. Buehn and Schneider (2012) examine a sample of 162 countries (including developing, high-income OECD, Eastern European, and Central Asian countries) and find that, on average, shadow economy size is roughly equivalent to $34 \%$ of GDP. According to their estimates, countries like Zimbabwe, Panama, and Bolivia reside towards the high end of the range with shadow economy sizes of $61.8,63.5$, and $66.1 \%$ of GDP, respectively (Buehn and Schneider, 2012, table 3). For such economies, extralegal activity is, in terms of value, more important than the formal economy.

While the shadow economy of the U.S. is almost certainly smaller than the world average, the available evidence suggests that the underground economy has, at least at times, 
played an important role. Neuwirth (2011, p. 117), for example, writes of the nation's black markets during World War II:

[I]n order to channel the nation's resources for World War II, the United States instituted stringent price controls. Yet, all across the land, people and producers smuggled products across state lines and price-gouged with impunity. As much as 80 percent of the nation's meat was sold above the price the government mandated, along with 60 to 90 percent of the country's lumber and one-third of all clothing. Gas was strictly rationed, but 2.5 million gallons a day disappeared, to be sold on the black market. And this doesn't count counterfeited ration coupons.

Sennholz (1984, p. 10) focuses on more recent events:

During the 1960s and 1970s, the U.S. Government, in cooperation with the state governments, destroyed millions of jobs. It forcibly raised the cost of labor through sizeable boosts in Social Security levies, unemployment taxes, Workman's Compensation expenses, Occupational Safety and Health Act expenses, and many other production costs. The mandated raises inevitably reduced the demand for labor and added millions of workers to the unemployment rolls. The boosts also reduced the take-home pay of the remaining workers as market adjustments shifted the new costs to the workers themselves. Both effects, the rising unemployment and the falling net wages, provided powerful stimuli to off-the-books employment.

And Buehn and Schneider's (2012, table 3) average estimate of the U.S. shadow economy from 1999 to 2007 is 8.6 percent of GDP. This is small only in a relative (to other countries) sense; it is by no means an economically negligible fraction of total economic activity. When government mandated prices result in shortages, underground markets step in to fill the void. Shadow economies provide goods and services that consumers demand, but are not available (or affordable) in the formal sector. As such, shadow economies often counter the intentions of political actors and, therefore, can have important policy implications. For example, large shadow economies often mean smaller bases from which governments may collect revenue to fund their liabilities. This, in turn, may result in higher budget deficits or tax rates (Schneider and 
Enste, 2000). Hence, political actors across the world scour for ways in which to bring shadow economy participants into the light (see deSoto, 1989, 2000; Neuwirth, 2011).

U.S. politicians certainly take shadow economic activity seriously. For example, in August 2012 the California state senate proposed legislation (California Senate Bill 1185) aimed at combating a growing underground economy. Estimates value California's underground economy somewhere between $\$ 60$ billion and $\$ 140$ billion annually. ${ }^{1}$ Previously, an article in the L.A. Times cited concern for California's growing informal sector: "Employers who pay their workers cash under the table to avoid payroll taxes, workers' compensation insurance and other government mandates are costing California about $\$ 7$ billion annually in lost tax revenue and undercutting companies that play by the rules [.] ${ }^{\prime 2}$ Similar reports can be found for other states. ${ }^{3}$

Only a few studies have examined shadow economies at the regional or state-level of particular nations (e.g., Buehn, 2011; Torgler et al., 2010; Chaudhari et al., 2006). To my knowledge, this paper presents the first attempt to measure U.S. states' individual shadow economies. Measuring a shadow economy, however, is a difficult task. The shadow designation implies a realm of economic activity in which its participants prefer to remain out of sight. ${ }^{4}$

Schneider et al. (2010) go so far as to assert that "doing research in this area can be considered as a scientific passion for knowing the unknown" (p. 444). Furthermore, there is much debate over the formal definition of shadow economy (see Schneider, 2011). I contend that shadow economic activity consists of market activity deliberately undertaken in a way that escapes detection by

\footnotetext{
${ }^{1}$ Estimates provided by California's Employment Development Department in analysis of SB 1185: http://www.leginfo.ca.gov/pub/11-12/bill/sen/sb_1151-1200/sb_1185_cfa_20120629_140323_asm_comm.html 2 "California Officials vow to crack down on underground economy," by Marc Lifsher, L.A. Times, December 09, 2011.

${ }^{3}$ See, for example, the Fiscal Policy Institutes' study, "The Underground Economy in the New York City Affordable Housing Construction Industry," April 17, 2007.

(http://www.fiscalpolicy.org/publications2007/FPI_AffordableHousingApril2007.pdf).

${ }^{4}$ The shadow economy has many synonyms. Among them are: underground, informal, extralegal, black market, hidden, parallel, System D, cash economies.
} 
public officials. While this definition potentially includes both activity that is illegal generally and that which would be legal if not purposefully hidden - by this definition, dealers of illegal narcotics and under-the-table moonlighters both contribute to the underground economy - the empirical methodology used here focuses more narrowly on otherwise legal market activity. ${ }^{5}$

A growing shadow economy can be described as a response of individuals who feel overburdened by the state. Participants either choose the 'exit option' (Schneider and Enste, 2000) if burdens in the formal sector grow sufficiently large, or, alternatively, they never choose the 'entry option' as they approach the productive periods of their lifetimes.

Most of the systematic empirical study of shadow economies has focused outside of the U.S. Buehn (2011) finds that, across regions of Germany, higher unit labor costs, unemployment, and tax burdens all contribute positively to shadow economy size, while stronger enforcement of tax rules and regulations reduce informal activity. Similarly, Chaudhari et al. (2006) evaluate variables that measure liberalization across India's states and find that growth in Indian shadow economies is reduced by greater liberalization. Torgler et al. (2010) examine regions of Switzerland and find that institutions in line with voters' preferences, and low tax burdens and regulatory barriers contribute to smaller shadow economies. ${ }^{6}$

\footnotetext{
${ }^{5}$ This is the common claim made in the literature, though one that is highly debatable. Consider, for example, the electricity consumption variable that will be used as an indicator in the analysis: electricity consumption statistics will measure electricity used for legal and illegal market activity, such as manufacturing marijuana.

${ }^{6}$ In the case of California's shadow economy "problem," an alternative perspective is offered. Flaming et al. (2005) suggest that in Los Angeles, where, according to their study "most net job growth [...] is occurring in the informal sector," the shadow economy is the direct result of relaxed government oversight. In their words: "workers are sandwiched between questionable employers, lack of rights, and economic desperation" (p.38). Indeed, recent studies find some support for Flaming et al. (2005). For example, Buehn and Schneider (2012) investigate several enforcement variables and find evidence that heightened enforcement reduces the size of the shadow economy. This brings to bear an interesting question: if taxes, social welfare, and regulatory burdens are the supposed cause of movement to the underground, can these very same burdens, channeled to greater oversight, be the solution? In other words, which might be the more effective policy for reducing shadow economy size: lower burdens, or enhanced oversight?
} 
The purpose of this paper is to construct reliable measures of shadow economy size for the 50 U.S. states over the period 1997 to $2008 .{ }^{7}$ In doing so, I investigate several of the aforementioned potential causes of underground activity. To my knowledge, this is the first comprehensive state-level study of U.S. shadow economies. For each state, I provide a complete annual time series of estimates for more than a decade. I build estimates of underground activity using a MIMIC (multiple indicators multiple causes) model - a structural equation model with a single latent variable. The MIMIC model, as its name suggests, makes use of several observed variables, separated into indicators and causes, to assess unobserved underground activity. Results suggest that tax and social welfare burdens, labor market regulations, and intensity of regulation enforcement are statistically significant determinants of shadow economy size.

The remainder of the paper is organized as follows: section 2.2 provides a discussion of the data used here and their role as causes and indicators of informal sector activity. Section 2.3 discusses the MIMIC model, section 2.4 provides empirical results, and section 2.5 concludes the investigation with some closing remarks.

\subsection{Theory and Measurement of Shadow Economies}

This analysis attempts to assess the size of underground economies at the state-level for the U.S. over the period 1997 to 2008 using a Multiple-Indicators-Multiple-Causes (MIMIC) model. The MIMIC model is a system of equations that relates both potential causes of shadow economic activity, and potential indicators that shadow economic activity is occurring to a measure of the shadow economy's size. What I mean here by the size of the shadow economy is the amount of economic output that is deliberately hidden from public officials and, therefore, not accounted

\footnotetext{
${ }^{7}$ District of Columbia is excluded from the study.
} 
for in official measures of state-level GDP. Having estimated shadow economy size, I report it for each state and year relative to measured income, or GDP.

The latent variable in the system is, of course, unobservable. In the case of the shadow economy, this is largely by the design of its participants. The intuition behind the MIMIC model is to use the observed cross-state variation in causes (e.g., regulatory activity) and indicators (e.g., electricity consumption) to estimate unobserved shadow economic activity. The analysis here runs along the lines of, e.g., Buehn and Schneider (2012) who use a MIMIC model and exploit cross-country variation in observable indicators and causes. In this section I discuss each of the indicator and cause variables that I incorporate. The technical details of estimating the MIMIC model will follow in section 2.3.

With this definition in mind, I consider the following determinants and indicators of the shadow economy that are suggested by both theory and previous studies.

\subsubsection{Determinants}

\section{Taxation, Charges, and Social Welfare Burdens}

Prominent in the shadow economy literature is analysis of the burdens of taxation and social welfare - social security payments, transfers, subsidies, etc. Tax and social welfare burdens have been identified among the leading contributors to shadow economy size (see e.g., Schneider, 2012; Buehn and Schneider, 2012; Buehn, 2011; Feld and Schneider, 2010). Intuitively, as the size of government's redistributive role increases the incentive to turn to the underground economy also increases. Where individuals find that they can avoid or evade taxes by opting to work or barter in the informal sector, they often will.

In order to measure tax and social program burdens I employ three measures: (1) indirect tax revenue as a percent of GDP; (2) current charges revenue as a percent of GDP; and (3) a 
measure of institutional quality - the Fraser Institute's Economic Freedom of North America index (EFNA) "size of government" component. Since both (1) and (2) represent tax and social burdens as a percent of GDP, I expect each of these revenue measures to correlate positively with shadow economy size. The freedom index, on the other hand, scores the size of government on a 0 to 10 scale. A score of 10 indicates a high degree of freedom from burden and is based on three underlying measures: general government consumption expenditures; transfers and subsidies; and social security payments - each of these measured as a percent of GDP. Since a higher score represents lower burden, I expect a negative relationship between the index score and shadow economy size.

\section{Labor Market Freedom}

Labor market regulations tend to distort labor costs. However, in the shadow economy literature, such regulations correlate in an ambiguous way with the shadow economy. ${ }^{9}$ On one hand, as the burdens of hiring, firing, or maintaining an employee in the official sector grow, employers and employees may opt to purchase or supply labor, respectively, in the shadow economy. These potential burdens arise in several forms - wage fixing, compensation requirements, competition from the public sector, union activity, etc. On the other hand, labor market regulations may very well attract participation in the formal sector, even if for short periods. One can imagine, for example, construction workers responding to changes in rules governing unemployment compensation. As the length of compensation periods increase, workers engaged in underground markets might find it profitable to enter the formal sector in order to meet minimum requirements for the program. Minimum wage adjustments, too, may invite marginal participants

\footnotetext{
${ }^{8}$ http://www.freetheworld.com/efna.html

9 See, for example, Kucera and Roncolato (2008) for an extensive survey of studies that examine labor market regulations against shadow economy outcomes.
} 
in the informal economy to engage more often in the formal sector. The ambiguity lies with the relative adjustments undertaken by potential employers versus employees.

To capture burdens placed on the labor market, I use two measures: (1) insurance trust expenditures (an aggregate of state-government unemployment compensation, employee retirement, and workers' compensation expenditures) as a percent of GDP; and (2) a measure of institutional quality expressed as the "labor market freedom" component of the EFNA index. This component captures the burdens employees and employers face with respect to three underlying subcomponents: minimum wage legislation, government employment, and union activity. The minimum wage score measures the annual income earned by persons working at the minimum wage as a percent of GDP per capita. A higher minimum wage to GDP per capita ratio suggests higher limits on the ability for employer-employee negotiation. ${ }^{10}$ Government employment is measured as a percent of total employment. A higher ratio of government employees to total employment suggests higher limits on the ability for individuals and firms to contract freely for labor services. This also suggests that perhaps government is attempting to provide higher levels of goods and services that would otherwise be found in the free market (Ashby et al., 2011). Union density is included to capture the potential for higher labor costs that accompany collective bargaining. ${ }^{11}$ Similar to the Government Size scores, the Labor Market Freedom scores are measured on a scale from 0 to 10. A score of 10 indicates a high degree of labor market freedom.

\footnotetext{
${ }^{10}$ For example, a minimum wage requirement of $\$ 2$ an hour in New York will have little impact, but for a developing nation, it might remove most potential workers from the effective workforce. The same idea holds, though in a narrower range, for jurisdictions within the United States (Ashby et al., 2011).

${ }^{11}$ Though individuals should have the right to organize for the purposes of collective bargaining, laws and regulations governing the labor market often force workers to join unions when they would rather not, and make it difficult to escape unionization where coercion can most easily be employed (Ashby, et al., 2011).
} 


\section{Regulatory Activity}

Participation in the underground economy also depends on the likelihood of detection by authorities. Buehn and Schneider (2012) find, using various enforcement measures across countries, that enforcement is a statistically significant determinant of shadow economy size. Importantly, they show that increased regulation serves as a shadow economy deterrent. It is therefore worthwhile to consider government regulatory enforcement as a potential informal sector deterrent here. Data on monitoring non-compliance in the formal economy, however, is rather limited. At the U.S. state-level, the Census Bureau's "Protective Inspection and Regulation (PIR)" expenditure is one potential proxy for government's commitment to enforcing regulation.

Campbell et al. (2010) build a case for including this measure alongside the EFNA on the grounds that the regulations listed under the PIR entry in the Census Bureau's Classification Manual have the same potential to impede economic activity as those currently covered by the EFNA. I contend that much of the stifled economic activity resulting from increased protective inspection and regulation potentially stems from detection of those performing the regulated activities in the informal sector - included in the Census Bureau's list, for example, are inspection and enforcement of licensing for barbers, beauticians, construction work, etc. ${ }^{12}$ Assuming successful application of the PIR expenditures, I expect a negative relationship between PIR and shadow economy size.

\footnotetext{
${ }^{12}$ See the Chapter 2 appendix for an abbreviated quote of the Census Bureau's Classification Manual entry for "Protective Inspection and Regulation." A definition of purpose, examples, and exclusions are provided.
} 


\subsubsection{Indicators}

\section{Official Economy ${ }^{13}$}

The state of the official economy is indicative of shadow economy size (see e.g., Buehn and Schneider, 2012; Schneider, 2011; Schneider et al., 2010; Schneider and Buehn, 2009). As market participants alternate between the formal and informal sectors, one can expect these changes to be reflected in measures of the official sector. A growing shadow economy, for example, extracts labor and other inputs from the official economy, potentially reducing its size. As individuals engage more in shadow economies, they give up use of their resources (e.g., time, human capital, etc.) in the formal sector. This implies a trade-off, in terms of earned income, between the formal and informal sectors. Thus, GDP per capita should correlate negatively with shadow economy size, all else equal.

\section{Electricity Consumption}

I use electricity consumption as a proportion of GDP as an indicator. A widely-used method of measuring the shadow economy indirectly is the electricity consumption method. Indeed, this method dominates much of the literature surveying the shadow economies of transitional nations of Central and Eastern Europe (see, e.g., Lacko, 1998, 1999, 2000a, 2000b; Johnson et al., 1997). This method considers the relationship between electricity consumption and GDP and is grounded on the assumption that production requires electricity in both the formal and informal sectors. In other words, electricity consumption data is more likely to capture "total" economic

\footnotetext{
${ }^{13}$ In other cases (particularly cross-country studies) GDP per capita is used as a control determinant for the shadow economy size. It is useful in this sense when considering nations that are relatively heterogeneous - developing nations, and combined observations of high-income and developing nations, are examples of such a mix. Buehn and Schneider (2012), for instance, alternate their use of GDP per capita as a determinant and an indicator variable depending on the mix of economies they are considering in various specifications. For their specifications that consider developing, transition, and all countries in the study - developing, transition, and high income - they use GDP per capita as a determinant. When they consider only high-income OECD countries in their specifications relatively homogeneous countries - they use GDP per capita as an indicator. Following Buehn and Schneider (2012), I consider real GDP per capita here as an indicator.
} 
activity than official measures of GDP. The difference between "total" and "official" economic activity then suggests underground activity. ${ }^{14}$ One criticism of using the electricity consumption method to measure shadow economy size is that it is too limited in scope (Schneider and Enste, 2000) - that is, informal market participants have at their disposal many other sources of energy that may be used for production (e.g., natural gas). It is still worthwhile to consider electricity consumption as a "total" measure relative to "official" measures of GDP, however, for the purposes of indicating underground activity. It offers the ability to capture at least some extralegal production.

\section{Labor Force Participation}

Shadow economies extract labor from the official sector. The U.S. labor force is defined as the portion of the civilian population age 16 and over who are non-institutionalized and either employed or unemployed and actively seeking work. ${ }^{15}$ It is certainly plausible that all members of the labor force may participate marginally in the shadow economy. However, it may be that as labor force participation declines relative to the broader civilian population, those who are no longer formally employed or job-seeking (i.e., no longer receiving unemployment benefits, etc.) are more likely to look for work in the shadow economy. I use data from the Bureau of Labor Statistics to measure growth in labor force participation. All else equal, positive (negative) growth in labor force participation may indicate a decrease (increase) in shadow economic activity.

Table 2.1 provides a summary description of all variables included in the analysis and discussed above. Before moving on to discuss empirical methodology, I provide a cursory glance

\footnotetext{
${ }^{14}$ For a more detailed discussion of the electricity consumption method, and other direct and indirect methods of measuring shadow economy, see Alderslade et al's (2006) comprehensive survey. For additional uses of the various methods and criticisms, see also Schneider and Enste (2000).

${ }^{15} \mathrm{http}: / /$ www.bls.gov/cps/cps_htgm.htm
} 
at the data to motivate the study. Figure 2.1 illustrates basic correlations between indirect tax as a percent of GDP (determinant) and several potential indicators of shadow economic activity using averages across the period 1997 to 2008. Figure 2.1 shows a negative (-3554.86) and statistically significant (at the 1\% level) relationship between indirect tax and Real GDP per capita; a positive (0.46) and statistically significant (at the 5\% level) relationship between indirect tax and electricity consumption (hundreds of kilowatt hours) as a fraction of GDP; and a negative (-1.46) relationship between indirect tax and the labor force participation rate, statistically significant at the $1 \%$ level. In terms of the effect that indirect taxation has on each of these indicator variables, the coefficients can be interpreted as the change associated with a 1 percentage point increase in indirect tax as a percent of GDP. In other words, such an increase in taxation is associated with approximately a $\$ 3600$ decrease in official sector per capita incomes; a 0.46 increase in electricity consumption as a fraction of GDP (the sample mean and standard deviation of this measure are 3.75 and 1.49 , respectively); and a 1.46 percentage point decline in labor force participation. Moreover, each of these relationships is consistent with the theory and expectations outlined above.

\subsection{Empirical Methodology}

The econometric method used in this paper to estimate the size of the shadow economy is the multiple indicators multiple causes (MIMIC) model. The MIMIC model used here is a structural equation model that assesses a single latent variable. Previous methods such as the electricity consumption approach or the currency demand approach rely exclusively on a single indicator to capture underground activity. The MIMIC model, as its name suggests, makes use of several 
observed variables, separated into indicators and causes, to assess unobserved underground activity.

Frey and Weck-Hanneman (1984) were the first to use this econometric methodology for the purpose of assessing the hidden economy. Others have since popularized the MIMIC approach for this purpose (see e.g., Schneider, 2012; Buehn and Schneider, 2012, Buehn, 2011; Dell'Anno and Solomon, 2008).

The purpose of a structural equation model such as MIMIC is to examine unobserved (or latent) variables expressed in terms of their relationships to observed variables. Specifically, the model assumes that the unobserved variable can be reconstructed from the observed variables' covariances. In this analysis, the single unobserved variable I wish to capture is the shadow economy. It will be explained using the covariance matrix of observed variables discussed in the previous section.

The MIMIC model makes simultaneous use of a measurement (factor analytical) model and a structural model. The former establishes a relationship between observed variables indicative of unobserved activity; the latter connects observed variables, serving as potential causes of the unobserved phenomena, to the latent variable. Thus, the MIMIC model equations can be stated in the following way:

$$
\begin{aligned}
& I=\text { BShadow }+\varepsilon \\
& \text { Shadow }=\varphi^{\prime} C+\mu
\end{aligned}
$$

where $I$ is a column vector of $i$ observed indicator variables, $i=1, \ldots, N$; Shadow is the latent variable; $C$ is a column vector of $j$ observed causal variables, $j=1, \ldots, J ; \beta$ is a column vector of coefficients for Shadow; $\varphi^{\prime}$ is a row vector of coefficients for $C$; $\varepsilon$ is an (ix1) error term for the measurement equation; and $\mu$ is a (scalar) error term for the structural equation. The error terms $\varepsilon$ 
and $\mu$ are assumed to be uncorrelated, with $\operatorname{var}(\mu)=\omega$, and $\operatorname{cov}(\varepsilon)=\emptyset$. Substituting equation (2.2) into equation (2.1) yields the following multivariate equation:

$$
I=\theta C+\delta
$$

where $\theta=\beta \varphi^{\prime}, \delta=\beta \mu+\varepsilon$, and $\operatorname{cov}(\delta)=\theta \theta^{\prime} \omega+\emptyset$.

For model (2.3) to be estimated, it requires that model (2.1) first be normalized. ${ }^{16}$ This is accomplished by setting one element of $\beta$ equal to 1 . Maximum likelihood estimation is then applied to the model.

In summary, populating equations (2.1) and (2.2) with the variables discussed in the previous section yields the following potential measurement and structural equations, respectively:

$\left[\begin{array}{c}\text { Real GDP Per Capita } \\ \text { Labor Force Participation Growth } \\ \text { Electricity Consumption }(\% \text { GDP })\end{array}\right]=\left[\begin{array}{c}\beta_{1} \\ \beta_{2} \\ 1\end{array}\right] *$ Shadow $+\varepsilon$

Shadow $=\left[\varphi_{1} \varphi_{2} \varphi_{3} \varphi_{4} \varphi_{5} \varphi_{6} \varphi_{7}\right] *\left[\begin{array}{c}\text { Government Size } \\ \text { Indirect Tax } \\ \text { Charges } \\ \text { Labor Market Freedom } \\ \text { Insurance Trust } \\ \text { Regulation Activity }\end{array}\right]+\mu$

Figure 2.2 presents a path diagram that, hopefully, summarizes the model with some intuitive perspective.

\footnotetext{
${ }^{16}$ A condition typical of simultaneous equations models is the singularity of the regression matrix. A similar condition arises for the error covariance matrix as the result of the normalization requirement for the measurement equation (Chaudhari, et al., 2006). For more on simultaneous equations modeling, see e.g., Bollen (1989).
} 


\subsection{Results}

\section{MIMIC Model Results}

Table 2.2 provides econometric results for MIMIC model regressions. A panel of the 50 U.S. states is examined across the period 1997 to 2008 (600 observations). The Census Bureau does not provide "productive inspection and regulation (PIR)" expenditure data for the years 2001 and 2003. In all specifications, I average the PIR data for years 2000/2002 and 2002/2004 to fill in missing data for 2001 and 2003, respectively. ${ }^{17}$ Specifications 2 and 3 are included as robustness checks. In these specifications, I remove the EFNA scores from the regressions and substitute, as a measure for government size, either government consumption expenditures as a percent of GDP (specification 2) or percent of the population receiving supplemental security income benefits for disability purposes (specification 3). This is done to remove any index element from the calculations and check the application of a more "direct" approach.

In specification 1, the cause variables government size, indirect tax revenue, charges, and regulation activity are statistically significant correlates and carry the expected signs. Labor market freedom is a statistically significant correlate and carries a negative sign (suggesting more labor market freedom causes lower participation in shadow economies); conversely, insurance trust, too, is a statistically significant correlate and carries a negative sign (suggesting greater government expenditures directed toward unemployment, employee retirement, and workers' compensation leads to less participation in the underground). This is consistent with the ambiguity discussed in section 2.2 regarding the sign of labor market regulation effects.

\footnotetext{
${ }^{17}$ Excluded from Table 2.2 are specifications which are regressed using only available data. Though regressions of this sort are run on a reduced number of observations, they yield no measurable difference in terms of economic and statistical significance of the coefficient estimates.
} 
Turning to indicator variables, these are the same across all specifications. Measures of labor force participation and real GDP per capita both carry the expected sign, but only real GDP per capita, however, exhibits statistical significance. The electricity consumption measure is used consistently across specifications as the fixed, a-priori value required in order to satisfy the MIMIC model identification rule (see section 2.3). It is important to recall equation (2.1) when interpreting coefficients listed in the "Indicator" section of Table 2.2. These coefficients represent $\beta$ s, and thus the effect of shadow economy size on the indicator variable.

Important for evaluating the above specifications is model goodness of fit. Table $\mathbf{2 . 2}$ includes two tests for goodness of fit: the chi-square or "exact fit" test and the Steiger and Lind (1980) root mean square error of approximation (RMSEA). ${ }^{18}$ The former is commonly evaluated as "fitting," if the chi-square statistic $\left(\chi^{2}\right)$ is smaller than the expected distribution value with a probability of occurrence greater than 0.05 (Barrett, 2007). By this measure, specifications 1 and 2 in Table 2.2 reveal a good fit (at the 5\% level, the critical values for 10 and 12 degrees of freedom, respectively, are 18.31 and 21.03).

Perhaps a more popular test for simultaneous equation model fit is RMSEA. RMSEA values of $0.01,0.05$, and 0.08 , as a general rule, indicate excellent, good, and fair (or mediocre) fit, respectively (see MacCallum, et al., 1996; Browne and Cudeck, 1993) when paired with probability of close fit (p-close) values greater than 0.10 . Results from RMSEA tests suggest specifications 1 and 2 in Table 2.2 are a good fit; specification 3 qualifies as fair. With these statistics in mind, I move on to estimate state-level shadow economy size.

\footnotetext{
${ }^{18}$ See Barrett (2007), MacCallum et al. (1996), and Browne and Cudeck (1993) for details regarding each of these tests.
} 


\section{Shadow Economy Estimates}

Estimating the size of the shadow economy from MIMIC model results requires two steps. First an index is constructed by applying the underlying time series to a model specified in

Table 2.2. I use specification 1 to estimate state-level shadow economy size: ${ }^{19}$

$S H A D O W_{i t}=-0.379 * G O V_{i t}+0.206 * T A X_{i t}+0.068 * C H G_{i t}-0.069 * L^{2} A B O R_{i t}-0.200 * I N S_{i t}-0.054 * R E G_{i t}$

In terms of standard deviation, government size has the largest effect on shadow economy size. A one-unit increase in the "size of government" $(G O V)$ score (which implies a higher degree of freedom from burden) leads to a 0.379 percentage point decrease in shadow economy size (significant at the $1 \%$ level). Taxes $(T A X)$ and charges $(C H G)$ as a percent of GDP are each positively correlated in a statistically significant way to shadow economy size (correlations are 0.206 and 0.068 , respectively, and each significant at the $1 \%$ level). A one-unit increase in the "labor market freedom" (LABOR) score (which implies a higher degree of labor market freedom) causes a 0.069 percentage point decrease in shadow economy size (significant at the $5 \%$ level). Insurance trust expenditures and protective inspection (INS) and regulation expenditures $(R E G)$ - each measured as a percent of GDP - both correlate negatively with shadow economy size (correlations are -0.200 and -0.054 ; significant at the $1 \%$ and $5 \%$ levels, respectively).

Since the underlying data are standardized, the index constructed, based on these results, yields state-level standard deviations of shadow economy size from the national average. ${ }^{20}$ The

\footnotetext{
${ }^{19}$ As a robustness check, I also estimate shadow economy size using estimates from specifications 2 and 3 . The results, whether generated by specifications 1,2, or 3 are highly correlated (a basic correlation matrix reveals no less than a 0.82 correlation between alternatives). Moreover, the rank order of shadow economy size (reported in Table 2.3) does not change in any meaningful way; for example, Delaware, Oregon, and Colorado maintain the smallest shadow economies, while West Virginia and Mississippi have the largest, respectively, in any case. Additionally, results from a specification not reported here that include all causal variables except Government Consumption as a percent of GDP yield similar results (highly correlated at 0.99 to those used to estimate shadow economy size), though the model is a weaker fit (by RMSEA and Chi test stats) than those reported.
} 
second step to constructing reliable shadow economy estimates is calibration. In this context, calibration means finding a base (average), exogenous estimate to which the index of standard deviations can be applied. I use Schneider (2010b) estimates of the U.S. shadow economy size for years 1997 to $2008 .^{21}$ Table 2.3 provides calibrated results for shadow economy size (\% GDP) at the U.S. state-level. It appears that, on average, shadow economy size has decreased for all states across the period 1997 to 2008 . This is consistent with other studies of shadow economies around the world. Schneider (2010b, table 3), for example, shows that shadow economy size decreased on average for most OECD countries across the same period leading up to the 2008 financial crisis. Post 2008, however, it appears shadow economy size is again on the rise for these same countries. This makes intuitive sense. As these economies entered recession, unemployment rates began to rise. According to the theory outlined in section 2.2 with regards to labor force participation in the official economy, as formal sector employment diminishes, and job-seekers' unemployment benefits dry up, individuals may turn to the informal sector to ease financial woes. It will be interesting to evaluate this trend at the U.S. state-level as the data becomes available.

States are also ranked by their average shadow economy size in Table 2.3. A rank of 1 indicates, among the 50 states in the study, the state with the smallest shadow economy as a percent of GDP. Delaware, Oregon, and Colorado rank 1, 2, and 3, respectively in terms of average shadow economy size across the period. Alternatively, West Virginia and Mississippi, on average, have the largest shadow economies in the U.S. as a percent of GDP.

\footnotetext{
${ }^{20}$ The state-level variables are standardized based on the national averages of the data.

${ }^{21}$ Schneider (2010b) estimates are calibrated using results from a cash demand approach. One notable criticism of the MIMIC model is its use for constructing a cardinal time series of shadow economy size. Since the MIMIC model can only produce an ordinal time series index, cardinal calibration requires use of past shadow economy estimates, ultimately dependent on other methods such as electricity consumption and currency demand. For additional discussion of both advantages and disadvantages of the MIMIC model approach to estimating shadow economy size, see the Schneider (2010a) appendix.
} 
In terms of standard deviation, Mississippi's shadow economy size, on average, is 1.26 percentage points (\% GDP) above the national average; the highest positive deviation recorded for the states. Delaware, by contrast, with the largest negative deviation, averaged 1.00 percentage points (\% GDP) below the national average; a remarkable difference! In terms of real GDP, Delaware's and Mississippi's shadow economies are valued (on average) at $\$ 3.6$ billion and $\$ 7.5$ billion, respectively. Both, however, are relatively small in absolute terms. By comparison, my estimates suggest California's average annual shadow economy is valued at approximately $\$ 117.5$ billion - which falls between California's Employment Development Department's $\$ 60$ to $\$ 140$ billion annual estimates mentioned in section 2.1 - and is the largest shadow economy in terms of total real income.

Interestingly, in terms of real GDP per capita, the story changes. Idaho, West Virginia, Montana, Mississippi, and Arkansas represent the 5 smallest shadow economies, respectively. Arkansas is the largest of the 5 with a shadow economy valued at approximately $\$ 2,700$ per capita. Alternatively, Massachusetts, Wyoming, Connecticut, Delaware, and Alaska represent the 5 largest (increasing in order) shadow economies on a real GDP per capita basis. Alaska, the largest, maintains an average annual shadow economy valued at $\$ 4,555$ per capita. This seems to suggest that where shadow economies are smaller relative to total state GDP, individuals that participate in underground activity extract higher incomes (measured by GDP) on a per capita basis. A plausible story might be that, given the smaller relative size of the shadow economy in such places as Delaware, informal participants can charge higher prices for their services. An informal construction laborer, for example, could most likely command higher prices for his or her services in places where both official sector incomes are higher, and informal labor is relatively scarce. Data on state-level informal sector populations, however, is not currently 
available. So whether or not supply of informal sector services drives these results is, at best, a guess.

A cursory look at income levels, however, provides some support for this hypothesis. Figure 2.3 illustrates the relationship between average shadow economy size as a percent of GDP and average real per capita GDP. The scatter plot shows that a 1 percentage point increase in shadow economy size relative to GDP is related to approximately a $\$ 10,200$ decrease in real GDP per capita (statistically significant at the $1 \%$ level). This is not all that surprising given the results provided in Table 2.3. Delaware, the smallest shadow economy size relative to GDP, is among the highest income states in terms of GDP per capita. West Virginia and Mississippi, two of the lowest ranked (Table 2.3) in terms of shadow economy size, are also among the lowest income states. Figure $\mathbf{2 . 4}$ provides a scatter of average real GDP levels against shadow economy size. The raw correlation suggests a 1 percentage point increase in shadow economy size relative to GDP is related to an approximate $\$ 201.3$ million decrease in real state-level GDP (statistically significant at the $1 \%$ level).

Figure 2.5 illustrates the per capita value of shadow economies against shadow economy size (as a percent of GDP). The raw correlation suggests that a 1 percentage point increase in shadow economy size is associated with an approximately $\$ 460$ lower per capita shadow economy GDP (statistically significant at the $1 \%$ level). Based on these results, it seems as though informal economy participants exploit the conditions of both the formal and informal sector. Where 'rules of the game' make it more costly to participate in underground activity, individual informal actors command higher incomes. Conversely, where the rules reduce the cost of underground activity, informal sector per capita GDP levels are lower. 
Another plausible story to high per capita informal GDP in small shadow economies might be that informal economy participants in states with large shadow economies are less productive. This is a reasonable assumption if human capital stocks correlate positively with institutional quality. A state with poor institutions, all else equal, will have a larger shadow economy as a percent of GDP, but it may also have relatively low human capital stock. Figure 2.6 plots institutional quality scores from the Economic Freedom of North America index against percent of states' populations with a bachelor's degree or higher. Data on educational attainment come from the U.S. Census Bureau. The raw correlation is positive (slope equals 2.41) and significant at the 5\% level. Figure 2.7 depicts percent of states' populations with a bachelor's degree or higher against shadow economy size. The raw correlation is negative (slope equals 4.77) and significant at the $1 \%$ level. These results support the low human capital, large shadow economy hypothesis. States such as West Virginia and Mississippi have very low human capital - if ranked across the 50 states in the study, West Virginia falls last, Mississippi ranks $48^{\text {th }}-$ and the largest shadow economies. Alternatively, Massachusetts and Colorado have the highest human capital stocks, respectively, but relatively small shadow economies.

Regardless of the underlying cause of high informal incomes in smaller relative shadow economies, the trade-off has an important implication. When shadow economy GDPs are added to official sector GDPs, the states' ranks on a GDP per capita basis do not change in any significant way. Table 2.4 provides states' ranks by GDP per capita. A larger rank represents lower income. Column 1 illustrates rank by official measures of GDP per capita. Column 2 illustrates rank when informal income is added to official income. Column 3 provides change in rank between columns 1 and 2 . 


\section{Robustness: Estimation Using the Electricity Consumption Method}

Finally, I estimate shadow economy size for 50 U.S. states using the aforementioned singlevariable electricity consumption approach following the methods of Kaufmann and Kaliberda (1996). Results are reported in Table 2.5. The founding assumption of this method is that since electricity is used in the production of goods and services in both the formal and informal sectors, electricity consumption data works well to capture total economic activity. This claim is supported, empirically, by world-wide observation of unitary electricity/GDP elasticity (Kaufmann and Kaliberda, 1996). Growth in electricity consumption, then, is considered to be nearly synonymous with growth in total (versus official) GDP.

For each year in the study, I calculate the difference between growth in state-level electricity consumption and growth in official measures of GDP. This difference amounts to GDP growth not captured by formal measures of GDP and serves as a proxy for growth in shadow economy incomes. Table $\mathbf{2 . 6}$ provides an example of the calculation method.

One notable criticism that applies to nearly all shadow economy size estimation techniques is reliance on baseline (exogenous) estimates to calibrate the estimates (see the calibration discussion above as it relates to the MIMIC method). ${ }^{22}$ To eliminate as many concerns as possible surrounding the arbitrary nature of the choice of exogenous estimates for

\footnotetext{
22 "Benchmarking," as calibrating estimates is often termed in the literature, raises some serious concerns with estimates of shadow economy size. Particularly, benchmarking techniques vary and the researcher's choice of which technique to use is completely arbitrary. There is no consensus on the best technique. Moreover, each estimate used as a benchmark itself was likely the result of some other benchmarking procedure. Another serious criticism concerning the use of the MIMIC method (since it is the most often used nowadays) is that the method was originally developed to measure intelligence and therefore unsuitable for economic purposes (see Breush, 2005, for a lengthy criticism of the MIMIC method in this vein). Schneider (2010a, p. 462) acknowledges "a strong difference between economic and psychological variables," but contends that the MIMIC approach cannot be eliminated. Though these criticisms should be (and are) taken seriously (see, e.g., Dell'Anno and Schneider, 2006; Schneider, 2010a; Schneider and Enste, 2000), there is no solid evidence that supports the MIMIC approach being more or less useful in either psychoanalysis or economics; or better or worse than any other approach to estimating shadow economy size.
} 
calibration, I benchmark both the MIMIC estimates and those constructed by the electricity consumption technique using data from the same source (Schneider, 2010b).

Results from the electricity consumption method (Table 2.5) are inconsistent with those from the MIMIC method (Table 2.3). First, results from the two methods are only moderately correlated $(0.25)$. In terms of shadow economy size, very few of the states' shadow economies, when measured by the electricity consumption method, are similar to their MIMIC method counterparts. In terms of rank, the smallest shadow economies as estimated by the MIMIC method all fall significantly farther down in rank when estimated using the electricity consumption method. For example, Delaware, Oregon, and Colorado fall from ranks 1, 2, and 3 to ranks 39, 10, and 20, respectively. Inconsistency between methods, however, is not uncommon.

Schneider and Enste (2000) compare world estimates for shadow economy size across various estimation techniques. They, too, find inconsistent results between methods. For example, average electricity consumption estimates around the year 1990 for the Central and South American countries of Brazil, Chile, Columbia, and Costa Rica suggest these countries' shadow economies were approximately 29.0, 37.0, 25.0, and 34.0\% of GDP, respectively (table 4). Conversely, MIMIC estimates for these same countries suggested shadow economy sizes close to $37.8,18.2,35.1$, and $23.2 \%$ of GDP, respectively (table 4). Not only do these estimates lack similarity in terms of shadow economy size, the rank order of the estimates also change.

While there is no consensus on the best method for evaluating shadow economy size, the MIMIC approach has dominated the literature for nearly two decades. One significant advantage that the MIMIC model holds over other estimation techniques is that it is an inherently more flexible estimation technique (Schneider, 2010a). The MIMIC model allows the researcher to (i) 
consider multiple variables related to shadow economic activity simultaneously, and (ii) vary the choice of causal and indicator variables. Single-variable methods such as the electricity consumption method are much more limited.

\subsection{Conclusion}

This paper evaluates multiple causes and multiple indicators of U.S. state-level underground economies using a MIMIC model estimation technique. Based on an index constructed with MIMIC model results, I present the first comprehensive estimates of shadow economy size for 50 U.S. states over the period 1997 to 2008. Shadow economy estimates based on the MIMIC index suggest that, on average, Delaware, Oregon, and Colorado maintain the smallest U.S. shadow economies, while West Virginia and Mississippi secure the largest as a percent of GDP. A cursory look at U.S. contiguous regions reveals that, on average, the shadow economies of southern states are largest ( $8.48 \%$ of GDP) across the period. Western states maintain the smallest shadow economies (on average $8.11 \%$ ). The sizes of all state shadow economies, however, appear to have decreased over the period.

Interestingly, high-income states tend to have the smallest relative shadow economies, but the highest underground GDP on a per capita basis. I speculate that this is likely due to a couple of factors: (1) relative scarcity of underground services provided in high-income states, which results in underground participants' ability to command higher prices, and/or (2) a lower level of human capital stock, and hence lower informal productivity in states with larger shadow economies (as a percent of GDP). Without reliable data on informal economy participation at the state-level, however, it is hard to say what is driving the high-income, small shadow economy trade-off. 
MIMIC model results suggest that tax and social welfare burdens, labor market regulations, and intensity of regulation enforcement are statistically significant determinants of the underground economy. Specifically, I find that U.S. shadow economy estimates rely positively on measures of tax and social welfare burdens, and government size, and negatively on measures of intensity of regulation enforcement. Perhaps most interesting, however, are the relationships between the shadow economy size and labor market variables. On one hand, results suggest that more labor market freedom (a score based on measures of minimum wage legislation, government employment, and union activity) causes lower participation in shadow economies. On the other hand, results suggest that higher levels of government insurance trust expenditures (an aggregate of expenditures directed toward unemployment, employee retirement, and workers' compensation) as a percent of GDP per capita also causes lower participation in the underground. In light of these empirical results, serious political efforts to reduce shadow economy size in the states might include reductions in both tax burdens and government spending.

Though efforts to inspect and regulate underground activity appear to discourage informal sector participation, results suggest these methods might be less effective than efforts to reduce fiscal burden. Furthermore, while government spending on unemployment, employee retirement, and workers' compensation appear to reduce the size of underground economies, these effects may be as short-lived as the benefits of the programs themselves. Examining the life of these effects, however, falls outside the scope of this chapter. 
FIGURE 2.1 - RELATIONSHIPS BETWEEN INDIRECT TAX (\% GDP) AND INDICATOR VARIABLES
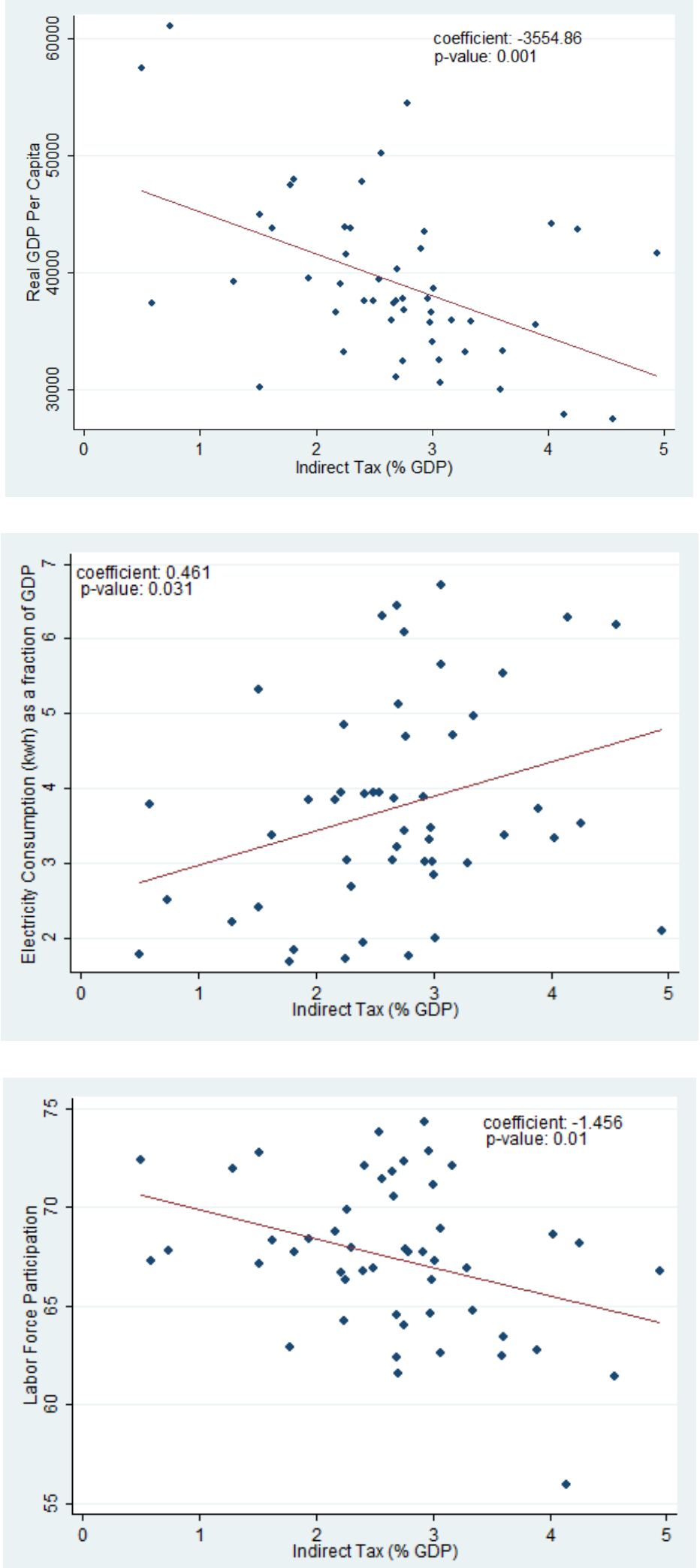
Causal

Indicators

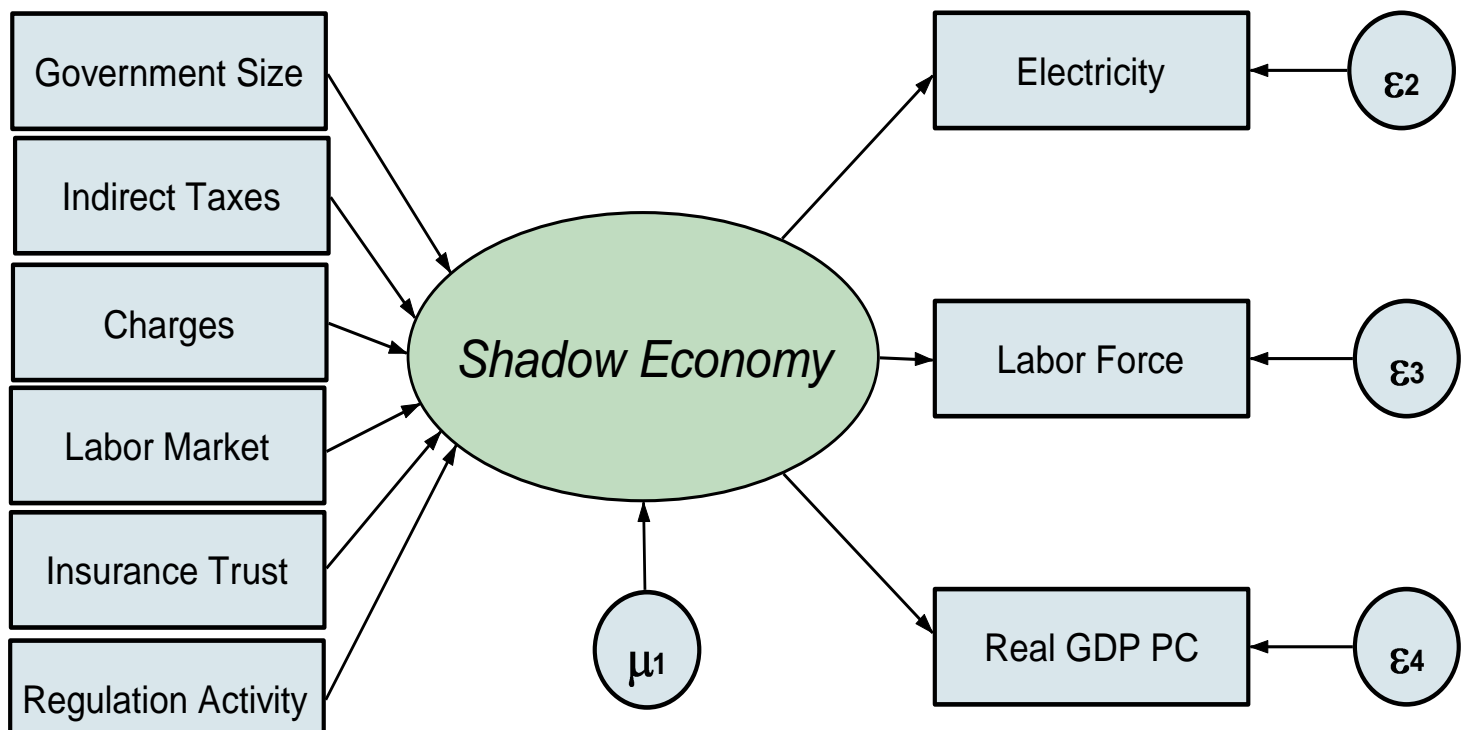


Figure 2.3 - REAL GDP PER CAPITA AgAinst ShAdow ECONOMY Size

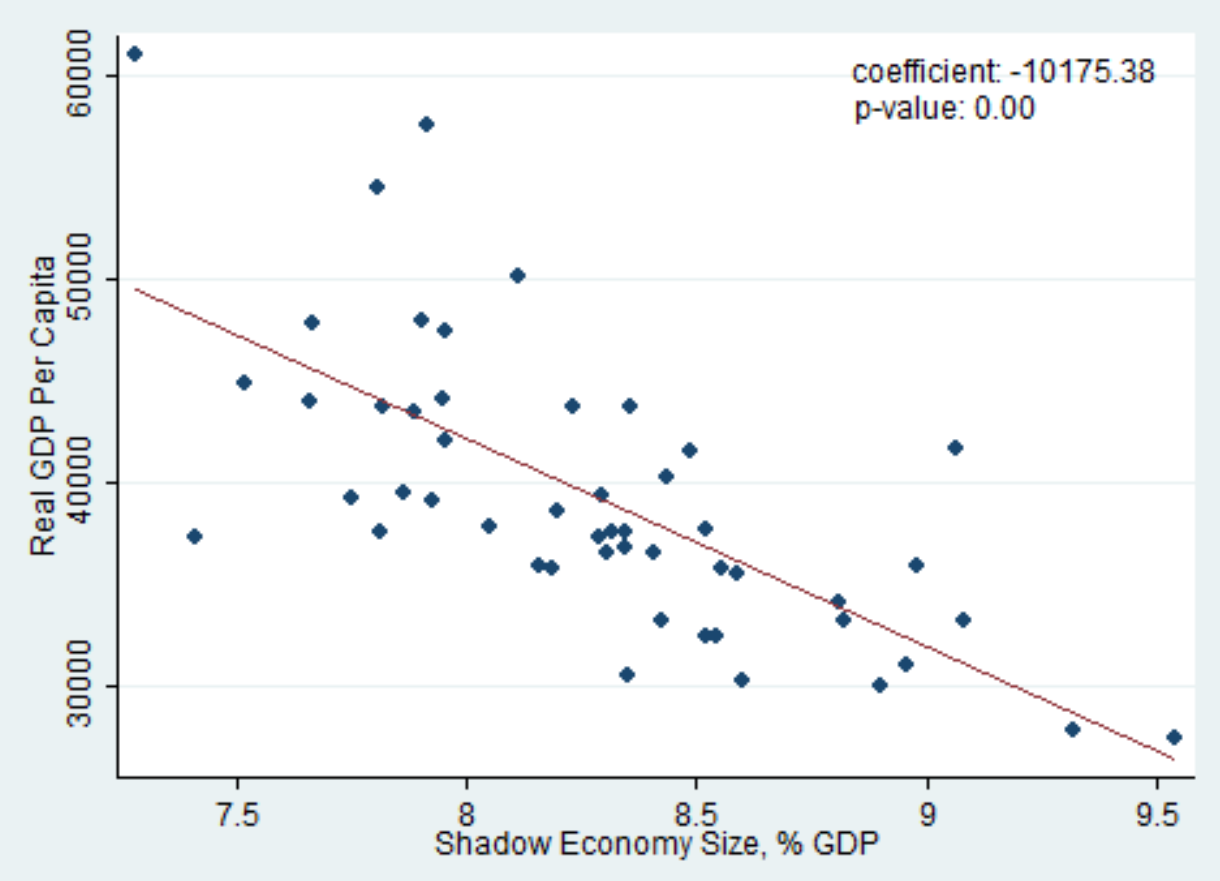

FigURE 2.4 - REAL GDP AGAINST SHADOW ECONOMY Size

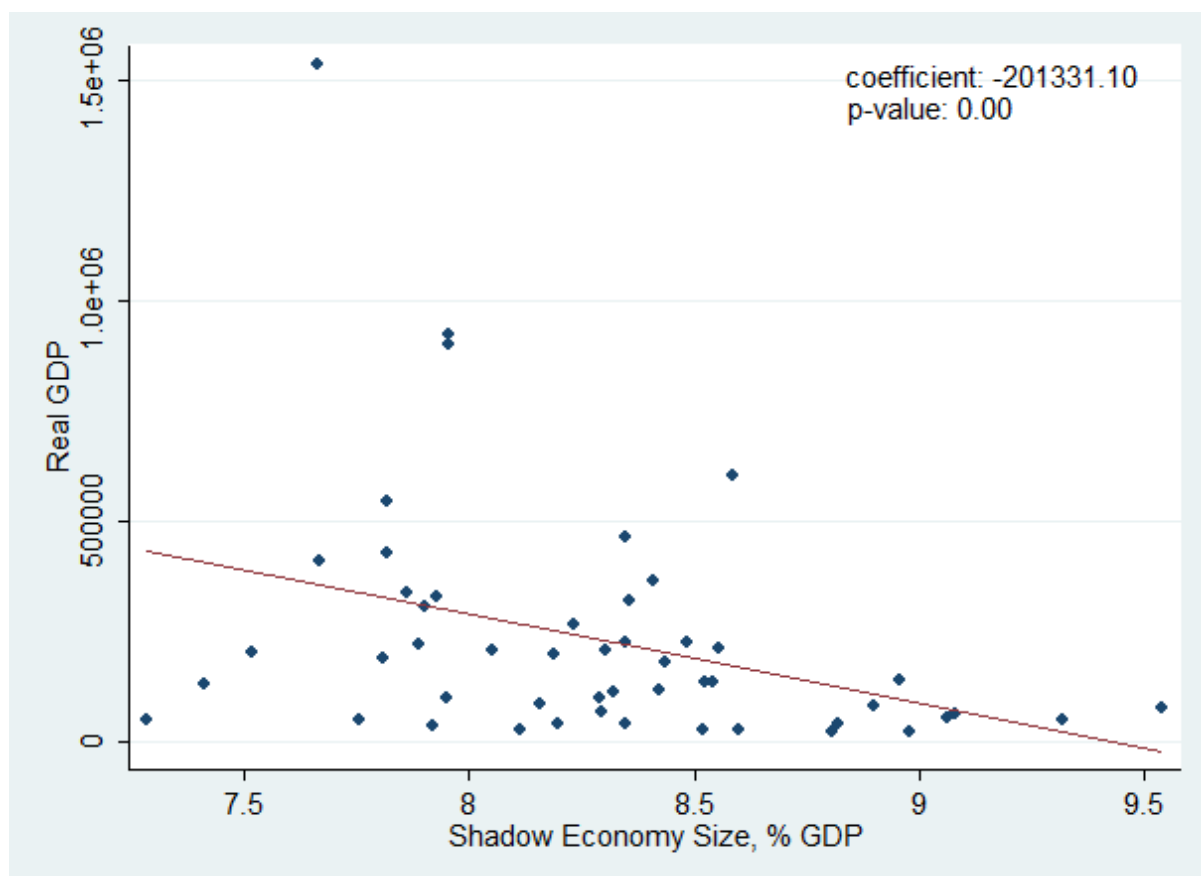


Figure 2.5 - Shadow Economy Value Per Capita against Shadow Economy Size

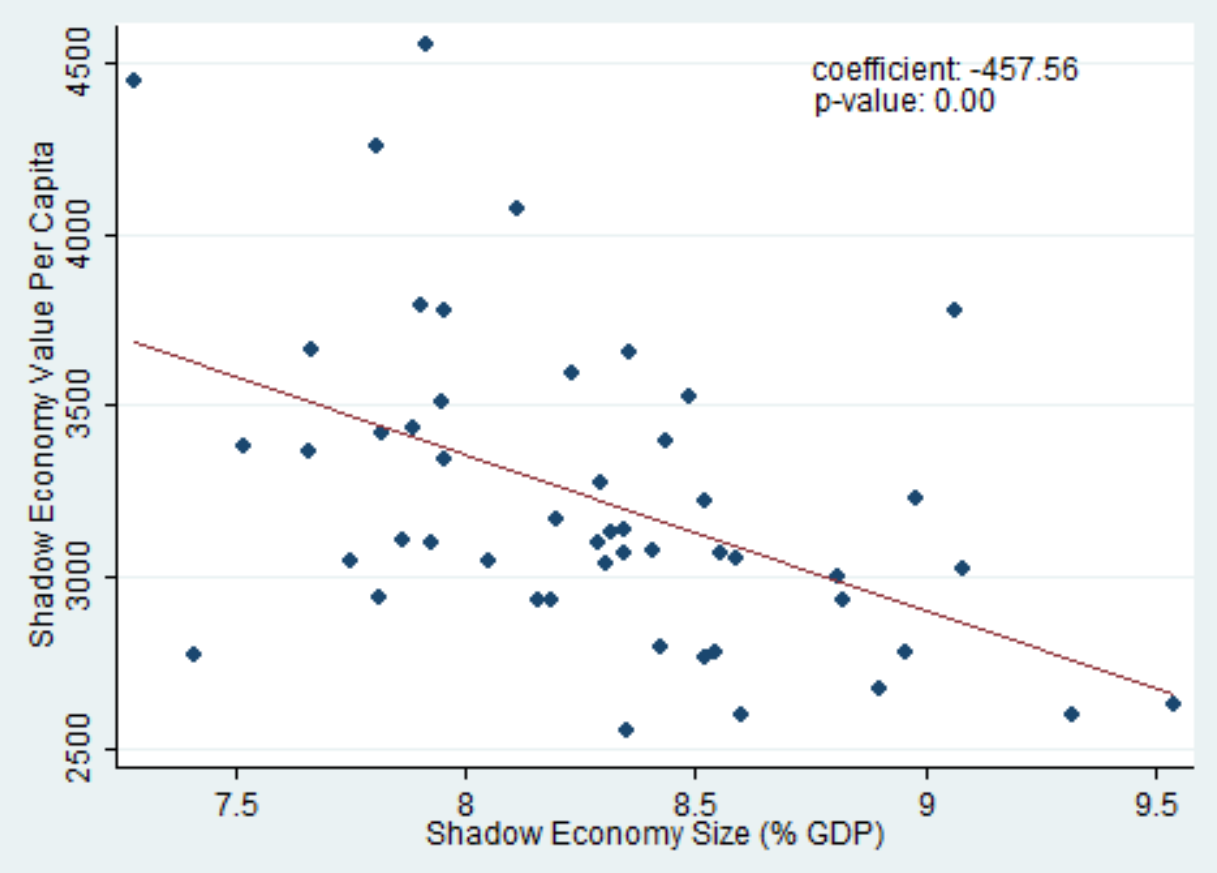

Figure 2.6 - Percent of Population with a BaChelor's Degree Or Higher against Institutional QUALITY

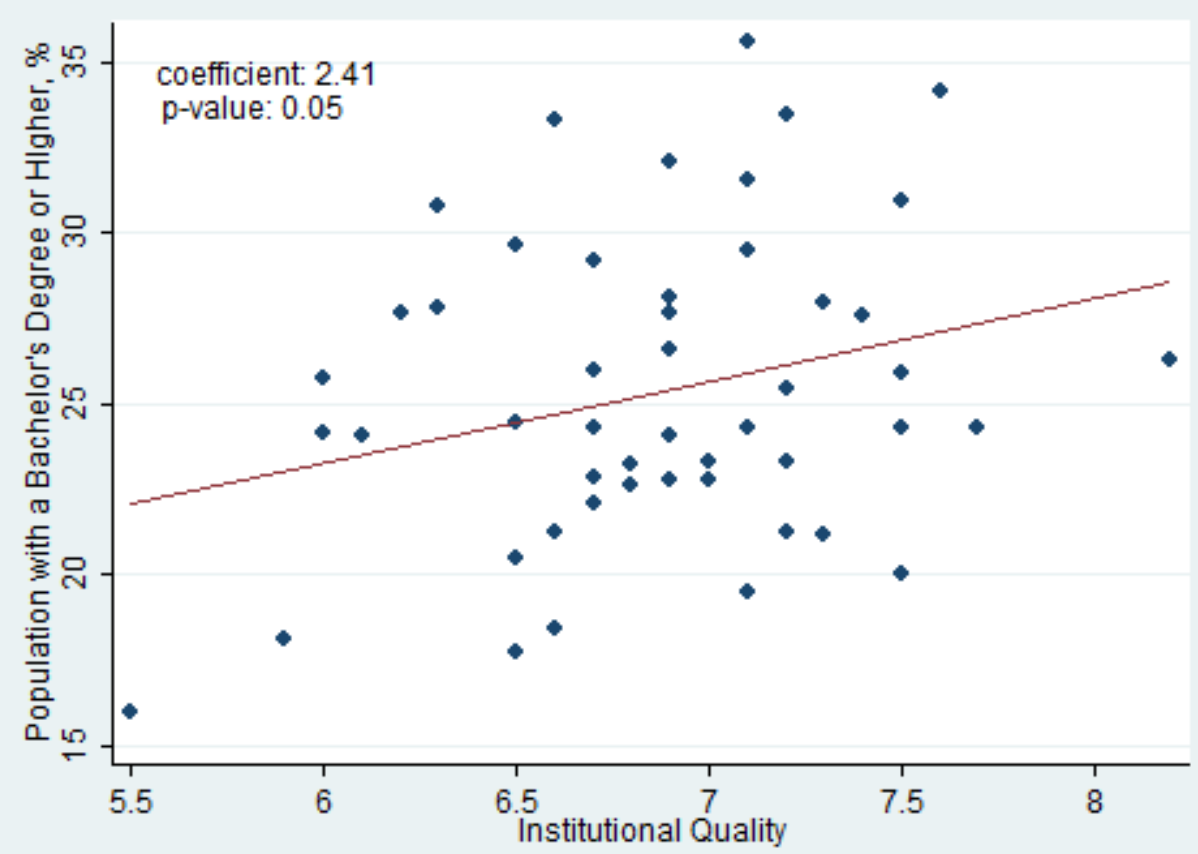


Figure 2.7 - Percent Of Population With A BaChelor's Degree Or Higher Against Shadow Economy SIZE

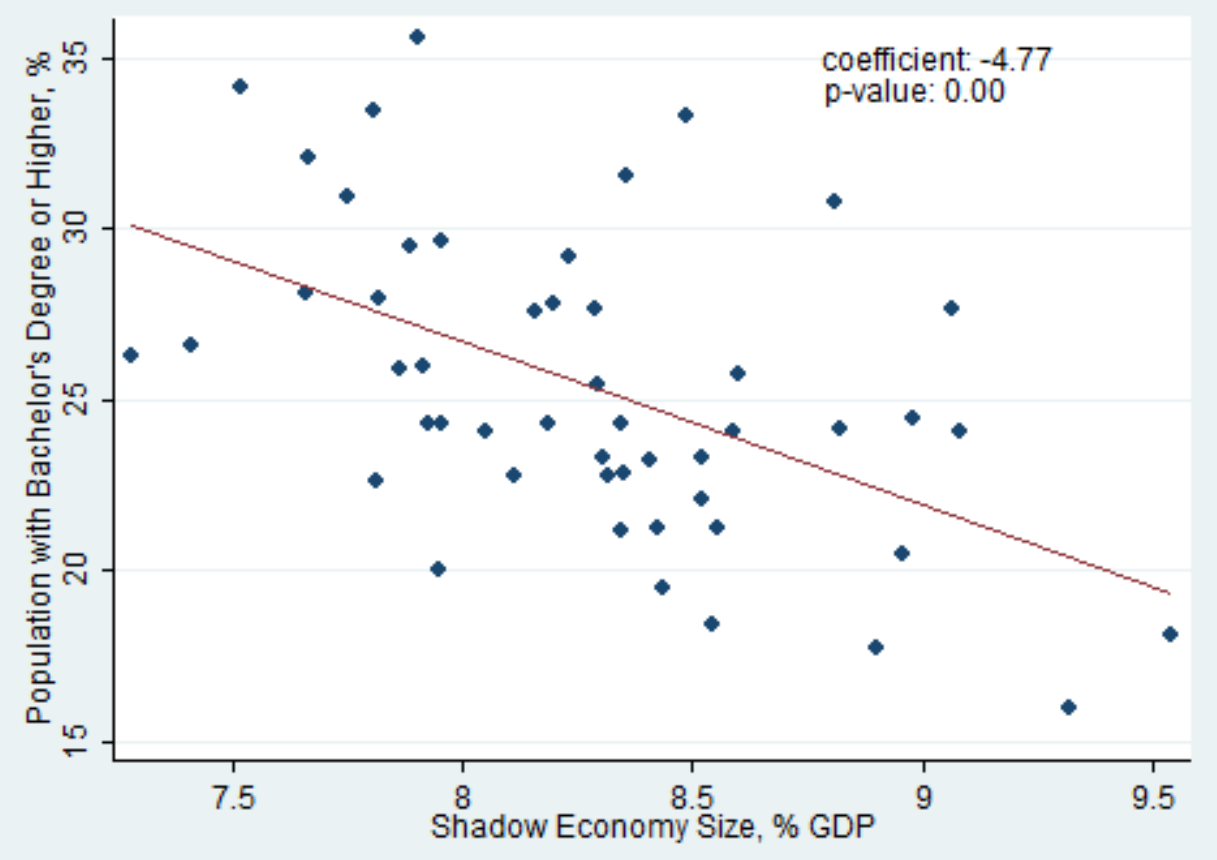


TABLE 2.1 - VARIABLES, DESCRIPTIONS, AND SOURCES

\begin{tabular}{|c|c|c|c|c|c|c|}
\hline Variable & Obs. & Mean & $\begin{array}{l}\text { Std. } \\
\text { Dev. }\end{array}$ & Min. & Max. & Description \\
\hline $\begin{array}{l}\text { Government } \\
\text { Size: } \text { EFNA }^{2}\end{array}$ & 600 & 7.16 & 0.94 & 2.5 & 9.1 & $\begin{array}{l}\text { A score composed of general government } \\
\text { consumption expenditures; transfers and } \\
\text { subsidies; and social security payments, each of } \\
\text { these measured as a percent of GDP. Score range } \\
\text { is } 1 \text { to } 10 \text {, with } 10 \text { representing small government. }\end{array}$ \\
\hline $\begin{array}{l}\text { Government Size } \\
\text { (alternative } \\
\text { measure) })^{1}\end{array}$ & 600 & 12.74 & 3.16 & 7.92 & 26.30 & $\begin{array}{l}\text { Government consumption expenditures as a } \\
\text { percent of GDP. }\end{array}$ \\
\hline $\begin{array}{l}\text { Disability } \\
\text { Benefits }^{6}\end{array}$ & 550 & 1.84 & 0.75 & 0.81 & 4.20 & $\begin{array}{l}\text { Percent of state population receiving supplemental } \\
\text { security income benefits for disability. }\end{array}$ \\
\hline $\begin{array}{l}\text { Indirect Tax } \\
\text { Revenue }^{1}\end{array}$ & 600 & 2.67 & 0.94 & 0.38 & 5.17 & $\begin{array}{l}\text { General and selective sales tax revenue as a } \\
\text { percent of GDP. }\end{array}$ \\
\hline Charges $^{1}$ & 600 & 1.17 & 0.45 & 0.44 & 2.76 & $\begin{array}{l}\text { Revenue from current charges (user fees and } \\
\text { fines) as a percent of GDP. }\end{array}$ \\
\hline $\begin{array}{l}\text { Labor Market } \\
\text { Freedom }^{2}\end{array}$ & 600 & 7.19 & 0.54 & 5.6 & 8.3 & $\begin{array}{l}\text { A score based on measures of minimum wage } \\
\text { legislation, government employment, and union } \\
\text { activity. Score range is } 1 \text { to } 10 \text {, with } 10 \\
\text { representing a high degree of labor market } \\
\text { freedom. }\end{array}$ \\
\hline $\begin{array}{l}\text { Insurance Trust } \\
\text { Expenditure }^{1}\end{array}$ & 600 & 1.28 & 0.51 & 0.36 & 4.03 & $\begin{array}{l}\text { An aggregate of state-government unemployment } \\
\text { compensation, employee retirement, and workers' } \\
\text { compensation expenditures as a percent of GDP. }\end{array}$ \\
\hline $\begin{array}{l}\text { Regulation } \\
\text { Activity }^{1}\end{array}$ & 600 & 0.09 & 0.04 & 0.02 & 0.28 & $\begin{array}{l}\text { "Protective Inspection and Regulation (PIR)" } \\
\text { expenditure as a percent of GDP. }\end{array}$ \\
\hline $\begin{array}{l}\text { Labor Force } \\
\text { Participation } \\
\text { Rate }^{3}\end{array}$ & 600 & 67.46 & 3.87 & 55.02 & 75.82 & $\begin{array}{l}\text { Percent of the non-institutionalized population, } \\
\text { age } 16+\text {, who are part of the labor force } \\
\text { (employed and unemployed) }\end{array}$ \\
\hline $\begin{array}{l}\text { Growth in Labor } \\
\text { Force } \\
\text { Participation }^{3}\end{array}$ & 600 & 1.01 & 1.05 & -4.69 & 4.95 & Growth in labor force participation. \\
\hline $\begin{array}{l}\text { Real GDP Per } \\
\text { Capita }^{4}\end{array}$ & 600 & $39,280.04$ & $7,463.54$ & $25,200.00$ & $65,476.00$ & GDP per capita in constant (2005) U.S. dollars. \\
\hline Electricity $^{5}$ & 600 & 3.75 & 1.49 & 1.27 & 8.10 & $\begin{array}{l}\text { Electricity (hundreds of kilowatt hours) consumed } \\
\text { as a proportion of GDP. }\end{array}$ \\
\hline
\end{tabular}

\section{Sources:}

1. State \& Local Government Finances, U.S. Department of Commerce, Census Bureau

2. Economic Freedom of North America, 2011, Fraser Institute

3. U.S. Department of Labor, Bureau of Labor and Statistics

4. U.S. Department of Commerce, Bureau of Economic Analysis

5. U.S. Energy Information Administration

6. Social Security Administration 
TABLE 2.2 - MIMIC MODEL REGRESSION RESULTS, 1997-2008

\begin{tabular}{|c|c|c|c|}
\hline \multicolumn{4}{|l|}{$\begin{array}{l}\text { Latent Variable: Shadow Economy } \\
\text { Independent Variables }\end{array}$} \\
\hline Specifications: & $(1)$ & $(2)$ & $(3)$ \\
\hline Government Size: EFNA Component 1 (-) & $\begin{array}{c}-0.379^{* * *} \\
(9.69)\end{array}$ & - & - \\
\hline Government Size: Government Consumption (\% GDP) (+) & - & $\begin{array}{l}0.019 \\
(0.51)\end{array}$ & - \\
\hline Disability Benefits (\% Population): & - & - & $\begin{array}{c}0.263^{* * * *} \\
(7.35)\end{array}$ \\
\hline Indirect Tax Revenue (\% GDP) (+) & $\begin{array}{c}0.206^{* * * *} \\
(7.64)\end{array}$ & $\begin{array}{c}0.305^{* * *} \\
(9.37)\end{array}$ & $\begin{array}{c}0.252^{* * *} \\
(8.39)\end{array}$ \\
\hline Charges ( $\%$ GDP) & $\begin{array}{c}0.068^{* * *} \\
(2.48)\end{array}$ & $\begin{array}{c}0.213^{* * *} \\
(6.33)\end{array}$ & $\begin{array}{c}0.222^{* * *} \\
(7.52)\end{array}$ \\
\hline Labor Market Freedom: EFNA Component $3(+/-)^{1}$ & $\begin{array}{c}-0.069^{* *} \\
(2.41)\end{array}$ & - & - \\
\hline Insurance Trust Expenditures (\% GDP) $(+/-)^{1}$ & $\begin{array}{c}-0.200^{* * * *} \\
(6.35)\end{array}$ & $\begin{array}{l}-0.031 \\
(0.92)\end{array}$ & $\begin{array}{l}-0.085^{* * *} \\
(2.79)\end{array}$ \\
\hline Regulation Activity (-) & $\begin{array}{c}-0.054^{* *} \\
(2.12)\end{array}$ & $\begin{array}{c}-0.073^{* * *} \\
(2.59)\end{array}$ & $\begin{array}{c}-0.059^{* *} \\
(2.03)\end{array}$ \\
\hline \multicolumn{4}{|l|}{ Indicators: } \\
\hline Growth in Labor Force Participation (-) & $\begin{array}{r}-0.033 \\
(0.53)\end{array}$ & $\begin{array}{r}-0.032 \\
(0.52)\end{array}$ & $\begin{array}{r}-0.057 \\
(0.90)\end{array}$ \\
\hline Real GDP Per Capita (-) & $\begin{array}{c}-1.294^{* * * *} \\
(15.93)\end{array}$ & $\begin{array}{c}-1.361^{* * * *} \\
(12.51)\end{array}$ & $\begin{array}{c}-1.186^{* * *} \\
(14.82)\end{array}$ \\
\hline Electricity (+) & 1 & 1 & 1 \\
\hline \multicolumn{4}{|l|}{ Statistics } \\
\hline $\begin{array}{l}\text { Chi-Square } \\
\text { Degrees of Freedom }(\mathrm{df}) \\
\text { (p-value) } \\
\text { RMSEA } \\
\text { (p-close) Probability RMSEA }<=0.05 \\
\mathrm{R}^{2} \\
\text { Observations }^{2}\end{array}$ & $\begin{array}{c}16.27 \\
\mathrm{df}=12 \\
(0.179) \\
0.024 \\
(0.940) \\
0.521 \\
600\end{array}$ & $\begin{array}{c}11.37 \\
\mathrm{df}=10 \\
(0.329) \\
0.015 \\
(0.961) \\
0.331 \\
600\end{array}$ & $\begin{array}{c}29.25 \\
\mathrm{df}=10 \\
(0.001) \\
0.059 \\
(0.242) \\
0.476 \\
550\end{array}$ \\
\hline
\end{tabular}

Notes: Absolute z-statistics are in parentheses below parameter estimates. Expected signs are in parentheses accompanying variable names. *, **, and *** denotes significance at the 10 percent, 5 percent, and 1 percent levels, respectively. All variables are standardized. Thus, all causal variable coefficients can be interpreted as standard deviations from the latent variable mean. Alternatively, indicator coefficients can be interpreted as the effect of shadow economy size on the indicator (see equation 2.1) in terms of standard deviation from the mean. The electricity variable has been chosen as the fixed, a-priori value indicator to satisfy the MIMIC model identification rule (see Section 3$)$. The degrees of freedom are determined by $0.5(p+q)(p+q+1)-t$, where $p$ is the number of indicators; $q$ is the number of causes, and $t$ is the number of free parameters (Schneider et al., 2010).

1. Ambiguous expectation (see Section 2)

2. The "Protective Inspection and Regulation" figures are not available for years 2001 and 2003. I have filled in the missing values with averages for years 2000/2002 and 2002/2004, respectively. 
TABLE 2.3 - U.S. STATE-LEVEL SHADOW ECONOMY ESTIMATES, (\% GDP), 1997-2008, MIMIC METHOD

\begin{tabular}{|c|c|c|c|c|c|c|c|c|c|c|c|c|c|c|}
\hline \multirow[b]{2}{*}{ State } & \multicolumn{12}{|c|}{ Years } & \multirow{2}{*}{$\begin{array}{l}\text { State } \\
\text { Avg. }\end{array}$} & \multirow{2}{*}{$\begin{array}{l}\text { State } \\
\text { Rank } \\
\end{array}$} \\
\hline & 1997 & 1998 & 1999 & 2000 & 2001 & 2002 & 2003 & 2004 & 2005 & 2006 & 2007 & 2008 & & \\
\hline Alabama & 9.52 & 9.56 & 9.35 & 9.39 & 9.42 & 9.43 & 9.20 & 9.10 & 8.86 & 8.09 & 7.86 & 7.72 & 8.96 & 45 \\
\hline Alaska & 8.28 & 8.53 & 8.53 & 8.50 & 8.59 & 8.64 & 8.09 & 7.73 & 7.87 & 6.97 & 6.80 & 6.49 & 7.92 & 13 \\
\hline Arizona & 8.77 & 8.75 & 8.55 & 8.62 & 8.57 & 8.64 & 8.42 & 8.35 & 8.09 & 7.38 & 7.09 & 7.01 & 8.19 & 21 \\
\hline Arkansas & 9.35 & 9.43 & 9.25 & 9.26 & 9.34 & 9.41 & 9.10 & 9.00 & 8.86 & 8.17 & 7.91 & 7.74 & 8.90 & 44 \\
\hline California & 8.44 & 8.44 & 8.24 & 8.13 & 8.16 & 8.05 & 7.83 & 7.64 & 7.47 & 6.76 & 6.45 & 6.33 & 7.66 & 4 \\
\hline Colorado & 8.21 & 8.30 & 8.03 & 8.00 & 7.95 & 7.89 & 7.65 & 7.55 & 7.30 & 6.66 & 6.39 & 6.27 & 7.52 & 3 \\
\hline Connecticut & 8.44 & 8.52 & 8.31 & 8.21 & 8.23 & 8.19 & 7.99 & 7.92 & 7.73 & 6.91 & 6.62 & 6.61 & 7.81 & 7 \\
\hline Delaware & 7.86 & 7.89 & 7.73 & 7.67 & 7.68 & 7.70 & 7.45 & 7.37 & 7.14 & 6.50 & 6.24 & 6.17 & 7.28 & 1 \\
\hline Florida & 9.36 & 9.35 & 9.07 & 9.09 & 8.97 & 8.96 & 8.70 & 8.58 & 8.30 & 7.73 & 7.50 & 7.41 & 8.59 & 40 \\
\hline Georgia & 8.55 & 8.47 & 8.24 & 8.21 & 8.25 & 8.27 & 8.05 & 7.97 & 7.78 & 7.10 & 6.82 & 6.64 & 7.86 & 10 \\
\hline Hawaii & 9.69 & 9.73 & 9.47 & 9.50 & 9.55 & 9.44 & 9.28 & 9.10 & 8.94 & 8.29 & 7.96 & 7.82 & 9.06 & 47 \\
\hline Idaho & 9.05 & 9.09 & 8.82 & 8.74 & 8.82 & 8.88 & 8.58 & 8.45 & 8.15 & 7.41 & 7.17 & 7.03 & 8.35 & 30 \\
\hline Illinois & 8.37 & 8.40 & 8.21 & 8.22 & 8.24 & 8.23 & 7.98 & 7.88 & 7.77 & 7.03 & 6.74 & 6.74 & 7.82 & 9 \\
\hline Indiana & 8.81 & 8.81 & 8.60 & 8.65 & 8.68 & 8.70 & 8.54 & 8.47 & 8.36 & 7.89 & 7.32 & 7.32 & 8.35 & 28 \\
\hline Iowa & 9.05 & 9.12 & 8.96 & 8.75 & 8.85 & 8.85 & 8.46 & 8.24 & 8.08 & 7.44 & 7.00 & 7.01 & 8.32 & 27 \\
\hline Kansas & 8.91 & 8.92 & 8.76 & 8.64 & 8.66 & 8.68 & 8.49 & 8.39 & 8.22 & 7.49 & 7.22 & 7.09 & 8.29 & 24 \\
\hline Kentucky & 9.05 & 9.09 & 8.72 & 8.93 & 8.96 & 8.96 & 8.74 & 8.61 & 8.50 & 7.82 & 7.43 & 7.66 & 8.54 & 38 \\
\hline Louisiana & 9.03 & 9.11 & 8.98 & 8.96 & 8.97 & 8.99 & 8.61 & 8.35 & 8.05 & 7.96 & 7.17 & 7.05 & 8.44 & 34 \\
\hline Maine & 9.35 & 9.52 & 9.20 & 9.05 & 9.14 & 9.17 & 9.01 & 8.98 & 8.81 & 8.14 & 7.82 & 7.65 & 8.82 & 43 \\
\hline Maryland & 9.13 & 9.12 & 8.90 & 8.92 & 8.90 & 8.83 & 8.69 & 8.60 & 8.27 & 7.83 & 7.36 & 7.28 & 8.49 & 35 \\
\hline Massachusetts & 8.60 & 8.56 & 8.32 & 8.24 & 8.31 & 8.19 & 8.04 & 7.99 & 7.83 & 7.15 & 6.80 & 6.78 & 7.90 & 12 \\
\hline Michigan & 8.91 & 8.99 & 8.68 & 8.71 & 8.76 & 8.76 & 8.58 & 8.51 & 8.36 & 7.69 & 7.45 & 7.51 & 8.41 & 32 \\
\hline Minnesota & 8.67 & 8.57 & 8.36 & 8.33 & 8.32 & 8.22 & 8.02 & 7.90 & 7.73 & 7.06 & 6.85 & 6.63 & 7.89 & 11 \\
\hline Mississippi & 9.78 & 9.93 & 9.83 & 9.96 & 9.98 & 10.00 & 9.71 & 9.49 & 9.48 & 9.61 & 8.53 & 8.19 & 9.54 & 50 \\
\hline Missouri & 8.85 & 8.92 & 8.70 & 8.65 & 8.69 & 8.72 & 8.49 & 8.39 & 8.24 & 7.54 & 7.30 & 7.14 & 8.30 & 26 \\
\hline Montana & 9.25 & 9.29 & 9.31 & 9.18 & 9.23 & 9.25 & 8.88 & 8.61 & 8.35 & 7.60 & 7.20 & 7.06 & 8.60 & 41 \\
\hline Nebraska & 8.88 & 8.90 & 8.68 & 8.71 & 8.72 & 8.81 & 8.62 & 8.44 & 8.23 & 7.46 & 7.07 & 7.03 & 8.30 & 25 \\
\hline Nevada & 8.61 & 8.59 & 8.34 & 8.41 & 8.45 & 8.36 & 8.13 & 8.00 & 7.82 & 7.13 & 6.83 & 6.70 & 7.95 & 15 \\
\hline New Hampshire & 8.35 & 8.38 & 8.12 & 8.11 & 8.15 & 8.15 & 7.97 & 7.78 & 7.67 & 6.95 & 6.74 & 6.66 & 7.75 & 6 \\
\hline New Jersey & 8.31 & 8.41 & 8.16 & 8.12 & 8.08 & 7.97 & 7.79 & 7.69 & 7.52 & 6.83 & 6.58 & 6.52 & 7.67 & 5 \\
\hline New Mexico & 9.59 & 9.82 & 9.55 & 9.60 & 9.69 & 9.57 & 9.28 & 9.09 & 8.88 & 8.13 & 7.93 & 7.82 & 9.08 & 48 \\
\hline New York & 8.60 & 8.64 & 8.38 & 8.33 & 8.35 & 8.28 & 8.15 & 8.12 & 7.86 & 7.14 & 6.89 & 6.71 & 7.95 & 16 \\
\hline North Carolina & 8.53 & 8.59 & 8.26 & 8.33 & 8.32 & 8.31 & 8.09 & 8.06 & 7.85 & 7.13 & 6.88 & 6.74 & 7.93 & 14 \\
\hline North Dakota & 9.75 & 9.64 & 9.62 & 9.58 & 9.65 & 9.79 & 9.28 & 8.87 & 8.71 & 7.97 & 7.53 & 7.32 & 8.98 & 46 \\
\hline
\end{tabular}




\begin{tabular}{|c|c|c|c|c|c|c|c|c|c|c|c|c|c|}
\hline Ohio & 8.42 & 8.35 & 8.17 & 8.17 & 8.19 & 8.11 & 7.92 & 7.85 & 7.75 & 7.11 & 7.03 & 6.71 & 7.81 \\
\hline Oklahoma & 9.07 & 9.15 & 8.92 & 8.85 & 8.98 & 9.07 & 8.70 & 8.44 & 8.22 & 7.49 & 7.20 & 6.99 & 8.42 \\
\hline
\end{tabular}

(Continued)

TABLE 2.3 - U.S. STATE-LEVEL SHADOW ECONOMY ESTIMATES (\% GDP), 1997-2008, MIMIC METHOD

(Continued)

\begin{tabular}{|c|c|c|c|c|c|c|c|c|c|c|c|c|c|c|}
\hline \multirow[b]{2}{*}{ State } & \multicolumn{12}{|c|}{ Years } & \multirow[b]{2}{*}{$\begin{array}{l}\text { State } \\
\text { Avg. }\end{array}$} & \multirow[b]{2}{*}{$\begin{array}{l}\text { State } \\
\text { Rank } \\
\end{array}$} \\
\hline & 1997 & 1998 & 1999 & 2000 & 2001 & 2002 & 2003 & 2004 & 2005 & 2006 & 2007 & 2008 & & \\
\hline Oregon & 8.22 & 8.10 & 7.98 & 7.90 & 7.98 & 7.91 & 7.52 & 7.31 & 7.22 & 6.52 & 6.22 & 6.05 & 7.41 & 2 \\
\hline Pennsylvania & 8.90 & 8.96 & 8.74 & 8.82 & 8.86 & 8.77 & 8.51 & 8.40 & 8.26 & 7.51 & 7.29 & 7.14 & 8.35 & 29 \\
\hline Rhode Island & 8.93 & 9.00 & 8.72 & 8.77 & 8.71 & 8.45 & 8.21 & 8.12 & 7.98 & 7.39 & 7.09 & 6.97 & 8.20 & 22 \\
\hline South Carolina & 9.10 & 9.11 & 8.86 & 8.92 & 8.96 & 8.87 & 8.65 & 8.55 & 8.41 & 7.78 & 7.61 & 7.43 & 8.52 & 37 \\
\hline South Dakota & 9.28 & 9.25 & 9.07 & 9.02 & 9.02 & 8.95 & 8.63 & 8.47 & 8.35 & 7.73 & 7.35 & 7.11 & 8.52 & 36 \\
\hline Tennessee & 9.11 & 9.08 & 8.85 & 8.93 & 8.92 & 8.95 & 8.82 & 8.70 & 8.54 & 7.78 & 7.49 & 7.51 & 8.56 & 39 \\
\hline Texas & 8.61 & 8.65 & 8.47 & 8.39 & 8.46 & 8.37 & 8.13 & 7.99 & 7.77 & 7.10 & 6.76 & 6.77 & 7.95 & 17 \\
\hline Utah & 8.77 & 8.80 & 8.62 & 8.60 & 8.62 & 8.65 & 8.40 & 8.28 & 8.08 & 7.30 & 7.01 & 6.78 & 8.16 & 20 \\
\hline Vermont & 9.10 & 9.18 & 9.05 & 9.09 & 9.14 & 9.16 & 8.93 & 8.94 & 8.88 & 8.25 & 8.02 & 7.94 & 8.81 & 42 \\
\hline Virginia & 9.06 & 9.02 & 8.74 & 8.71 & 8.76 & 8.73 & 8.51 & 8.46 & 8.23 & 7.55 & 7.30 & 7.19 & 8.36 & 31 \\
\hline Washington & 8.86 & 8.85 & 8.53 & 8.60 & 8.68 & 8.56 & 8.43 & 8.37 & 8.16 & 7.51 & 7.21 & 7.02 & 8.23 & 23 \\
\hline West Virginia & 9.74 & 9.80 & 9.61 & 9.72 & 9.73 & 9.32 & 9.32 & 9.47 & 9.53 & 8.86 & 8.42 & 8.32 & 9.32 & 49 \\
\hline Wisconsin & 8.67 & 8.71 & 8.53 & 8.54 & 8.42 & 8.42 & 8.21 & 8.13 & 7.92 & 7.23 & 6.98 & 6.83 & 8.05 & 18 \\
\hline Wyoming & 8.64 & 8.89 & 8.67 & 8.71 & 8.64 & 8.67 & 8.33 & 8.20 & 7.95 & 7.18 & 6.78 & 6.70 & 8.11 & 19 \\
\hline U.S. Average & 8.89 & 8.93 & 8.72 & 8.71 & 8.73 & 8.71 & 8.46 & 8.34 & 8.17 & 7.51 & 7.18 & 7.07 & & \\
\hline
\end{tabular}


TABle 2.4 - U.S. STATE-LEVEL RANK BY GDP PER CAPITA

\begin{tabular}{|c|c|c|c|}
\hline State & $\begin{array}{l}\text { Shadow Economy } \\
\text { GDP Excluded }\end{array}$ & $\begin{array}{l}\text { Shadow Economy } \\
\text { GDP Included }\end{array}$ & $\begin{array}{c}\text { Change in } \\
\text { Rank }\end{array}$ \\
\hline Alabama & 45 & 45 & 0 \\
\hline Alaska & 2 & 2 & 0 \\
\hline Arizona & 37 & 37 & 0 \\
\hline Arkansas & 48 & 48 & 0 \\
\hline California & 10 & 11 & -1 \\
\hline Colorado & 8 & 8 & 0 \\
\hline Connecticut & 3 & 3 & 0 \\
\hline Delaware & 1 & 1 & 0 \\
\hline Florida & 38 & 38 & 0 \\
\hline Georgia & 19 & 20 & -1 \\
\hline Hawaii & 16 & 15 & 1 \\
\hline Idaho & 46 & 46 & 0 \\
\hline Illinois & 11 & 13 & -2 \\
\hline Indiana & 31 & 31 & 0 \\
\hline Iowa & 26 & 26 & 0 \\
\hline Kansas & 30 & 29 & 1 \\
\hline Kentucky & 43 & 43 & 0 \\
\hline Louisiana & 18 & 18 & 0 \\
\hline Maine & 41 & 41 & 0 \\
\hline Maryland & 17 & 17 & 0 \\
\hline Massachusetts & 5 & 5 & 0 \\
\hline Michigan & 33 & 33 & 0 \\
\hline Minnesota & 14 & 14 & 0 \\
\hline Mississippi & 50 & 50 & 0 \\
\hline Missouri & 32 & 32 & 0 \\
\hline Montana & 47 & 47 & 0 \\
\hline Nebraska & 20 & 19 & 1 \\
\hline Nevada & 9 & 9 & 0 \\
\hline New Hampshire & 21 & 21 & 0 \\
\hline New Jersey & 6 & 6 & 0 \\
\hline New Mexico & 40 & 40 & 0 \\
\hline New York & 7 & 7 & 0 \\
\hline North Carolina & 22 & 22 & 0 \\
\hline North Dakota & 34 & 34 & 0 \\
\hline Ohio & 27 & 28 & -1 \\
\hline Oklahoma & 42 & 42 & 0 \\
\hline Oregon & 29 & 30 & -1 \\
\hline
\end{tabular}


TABle 2.4 - U.S. STATE-LeVel RANK BY GDP Per CaPita (Continued)

\begin{tabular}{rccc}
\hline \multicolumn{1}{c}{ State } & $\begin{array}{c}\text { Shadow Economy } \\
\text { GDP Excluded }\end{array}$ & $\begin{array}{c}\text { Shadow Economy } \\
\text { GDP Included }\end{array}$ & $\begin{array}{c}\text { Change in } \\
\text { Rank }\end{array}$ \\
\hline \hline Pennsylvania & 28 & 27 & 1 \\
Rhode Island & 23 & 23 & 0 \\
South Carolina & 44 & 44 & 0 \\
South Dakota & 25 & 24 & 1 \\
Tennessee & 36 & 35 & 1 \\
Texas & 15 & 16 & -1 \\
Utah & 35 & 36 & -1 \\
Vermont & 39 & 39 & 0 \\
Virginia & 12 & 10 & 2 \\
Washington & 13 & 12 & 1 \\
West Virginia & 49 & 49 & 0 \\
Wisconsin & 24 & 25 & -1 \\
Wyoming & 4 & 4 & 0 \\
\hline \hline & & & \\
\hline \hline
\end{tabular}


TABLE 2.5 - U.S. STATE-LEVEL SHADOW ECONOMY ESTIMATES, (\% GDP), 1997-2008, ELECTRICITY CONSUMPTION METHOD

\begin{tabular}{|c|c|c|c|c|c|c|c|c|c|c|c|c|c|c|}
\hline \multirow[b]{2}{*}{ State } & \multicolumn{12}{|c|}{ Years } & \multirow[b]{2}{*}{$\begin{array}{l}\text { State } \\
\text { Avg. }\end{array}$} & \multirow[b]{2}{*}{$\begin{array}{l}\text { State } \\
\text { Rank } \\
\end{array}$} \\
\hline & 1997 & 1998 & 1999 & 2000 & 2001 & 2002 & 2003 & 2004 & 2005 & 2006 & 2007 & 2008 & & \\
\hline Alabama & 8.57 & 9.11 & 8.74 & 8.89 & 8.12 & 8.32 & 8.27 & 8.15 & 8.39 & 8.88 & 9.26 & 10.01 & 8.73 & 47 \\
\hline Alaska & 8.54 & 9.53 & 9.48 & 8.99 & 9.02 & 8.60 & 8.19 & 7.99 & 7.92 & 8.23 & 8.17 & 8.09 & 8.56 & 44 \\
\hline Arizona & 8.33 & 7.75 & 7.25 & 7.18 & 6.97 & 6.66 & 6.49 & 6.47 & 6.32 & 6.39 & 6.64 & 6.95 & 6.95 & 2 \\
\hline Arkansas & 8.66 & 8.40 & 7.77 & 8.00 & 8.09 & 7.28 & 6.96 & 6.66 & 7.46 & 7.91 & 7.63 & 7.95 & 7.73 & 25 \\
\hline California & 8.64 & 7.76 & 7.07 & 7.13 & 8.46 & 8.43 & 7.97 & 7.37 & 7.06 & 7.59 & 7.31 & 7.12 & 7.66 & 24 \\
\hline Colorado & 8.05 & 7.82 & 7.28 & 6.84 & 6.85 & 6.88 & 7.65 & 7.52 & 7.96 & 7.68 & 7.67 & 8.32 & 7.54 & 20 \\
\hline Connecticut & 8.09 & 7.69 & 7.34 & 6.37 & 6.37 & 6.51 & 6.79 & 6.41 & 7.44 & 8.26 & 9.41 & 9.30 & 7.50 & 19 \\
\hline Delaware & 8.75 & 8.38 & 8.32 & 6.96 & 7.35 & 7.88 & 7.66 & 7.21 & 7.12 & 8.61 & 9.40 & 10.39 & 8.17 & 39 \\
\hline Florida & 8.50 & 8.31 & 7.52 & 7.42 & 8.07 & 7.59 & 7.73 & 7.58 & 7.65 & 8.69 & 8.35 & 8.64 & 8.00 & 35 \\
\hline Georgia & 8.24 & 8.37 & 7.53 & 7.49 & 7.33 & 7.31 & 7.14 & 7.40 & 8.09 & 8.08 & 8.08 & 8.84 & 7.82 & 29 \\
\hline Hawaii & 8.88 & 8.13 & 8.25 & 9.55 & 9.40 & 8.57 & 9.09 & 9.39 & 9.94 & 10.55 & 10.33 & 13.60 & 9.64 & 50 \\
\hline Idaho & 8.50 & 8.25 & 7.55 & 7.14 & 7.72 & 8.31 & 7.58 & 6.55 & 6.07 & 5.85 & 5.84 & 6.51 & 7.16 & 5 \\
\hline Illinois & 8.37 & 8.01 & 7.15 & 6.83 & 6.68 & 6.68 & 6.23 & 5.98 & 6.12 & 5.76 & 6.83 & 7.34 & 6.83 & 1 \\
\hline Indiana & 8.46 & 8.23 & 8.22 & 7.68 & 7.78 & 7.80 & 7.33 & 7.43 & 7.85 & 8.26 & 8.17 & 8.73 & 8.00 & 34 \\
\hline Iowa & 8.70 & 8.88 & 8.51 & 8.17 & 8.47 & 8.19 & 7.89 & 7.37 & 7.77 & 7.99 & 7.49 & 7.60 & 8.09 & 37 \\
\hline Kansas & 8.25 & 8.25 & 7.71 & 7.81 & 7.42 & 7.49 & 7.14 & 7.01 & 7.21 & 7.27 & 6.70 & 6.98 & 7.44 & 15 \\
\hline Kentucky & 8.19 & 7.98 & 7.94 & 7.91 & 7.97 & 8.39 & 8.21 & 8.32 & 8.86 & 9.05 & 9.88 & 10.51 & 8.60 & 46 \\
\hline Louisiana & 8.27 & 7.83 & 7.68 & 8.41 & 7.95 & 7.17 & 7.28 & 6.95 & 6.57 & 6.55 & 6.71 & 7.25 & 7.39 & 11 \\
\hline Maine & 8.62 & 8.08 & 7.82 & 7.37 & 7.67 & 6.72 & 6.40 & 6.10 & 6.49 & 6.91 & 8.03 & 7.42 & 7.30 & 7 \\
\hline Maryland & 8.17 & 7.94 & 7.65 & 7.04 & 6.52 & 6.41 & 6.65 & 6.46 & 7.08 & 7.65 & 8.79 & 9.32 & 7.47 & 18 \\
\hline Massachusetts & 8.56 & 7.51 & 6.74 & 6.80 & 8.15 & 7.10 & 7.47 & 7.39 & 8.21 & 9.80 & 9.41 & 9.62 & 8.06 & 36 \\
\hline Michigan & 8.34 & 8.32 & 8.12 & 7.82 & 7.49 & 7.47 & 7.28 & 7.16 & 7.53 & 8.28 & 8.55 & 9.07 & 7.95 & 33 \\
\hline Minnesota & 8.41 & 8.17 & 7.95 & 7.67 & 7.71 & 7.36 & 7.35 & 7.15 & 7.57 & 7.85 & 8.28 & 8.45 & 7.83 & 30 \\
\hline Mississippi & 8.43 & 8.64 & 8.02 & 8.32 & 8.46 & 8.40 & 8.19 & 8.56 & 8.77 & 9.43 & 8.63 & 9.26 & 8.59 & 45 \\
\hline Missouri & 8.35 & 8.36 & 7.95 & 7.90 & 7.79 & 7.77 & 7.30 & 7.03 & 7.49 & 7.55 & 7.89 & 7.82 & 7.77 & 27 \\
\hline Montana & 8.00 & 8.38 & 7.86 & 8.38 & 7.96 & 7.61 & 7.58 & 7.36 & 7.44 & 7.31 & 7.83 & 8.20 & 7.83 & 31 \\
\hline Nebraska & 9.03 & 9.07 & 8.59 & 8.63 & 8.56 & 8.89 & 8.39 & 8.08 & 8.33 & 8.24 & 8.24 & 8.48 & 8.54 & 43 \\
\hline Nevada & 8.13 & 7.90 & 7.71 & 7.92 & 9.89 & 10.53 & 9.88 & 9.33 & 8.92 & 9.41 & 9.34 & 9.22 & 9.02 & 48 \\
\hline New Hampshire & 8.28 & 8.08 & 8.04 & 7.24 & 7.07 & 6.56 & 6.80 & 6.78 & 7.34 & 7.68 & 7.61 & 7.71 & 7.43 & 14 \\
\hline New Jersey & 8.29 & 7.97 & 7.73 & 6.71 & 6.66 & 6.52 & 6.54 & 6.90 & 7.38 & 7.42 & 8.08 & 8.63 & 7.40 & 12 \\
\hline New Mexico & 8.26 & 8.73 & 7.97 & 8.06 & 8.45 & 7.89 & 7.64 & 7.13 & 7.44 & 7.18 & 7.24 & 7.77 & 7.81 & 28 \\
\hline New York & 8.24 & 7.68 & 7.15 & 7.78 & 7.61 & 7.39 & 7.87 & 7.54 & 8.09 & 7.80 & 7.75 & 8.18 & 7.76 & 26 \\
\hline North Carolina & 8.08 & 7.89 & 7.22 & 7.14 & 6.94 & 7.08 & 6.93 & 6.92 & 6.71 & 6.50 & 6.72 & 6.55 & 7.06 & 4 \\
\hline North Dakota & 8.82 & 8.24 & 8.71 & 8.40 & 8.43 & 8.15 & 7.61 & 7.62 & 7.73 & 7.98 & 7.98 & 7.77 & 8.12 & 38 \\
\hline Ohio & 8.18 & 8.00 & 7.94 & 7.62 & 7.38 & 7.14 & 6.84 & 6.78 & 6.98 & 7.15 & 7.51 & 7.87 & 7.45 & 16 \\
\hline
\end{tabular}


TABLE 2.5 - U.S. STATE-LEVEL ShadOW ECONOMY EsTiMATES (\% GDP), 1997-2008, ELECTRICITY CONSUMPTION METHOD (Continued)

\begin{tabular}{|c|c|c|c|c|c|c|c|c|c|c|c|c|c|c|}
\hline \multirow[b]{2}{*}{ State } & \multicolumn{12}{|c|}{ Years } & \multirow[b]{2}{*}{$\begin{array}{l}\text { State } \\
\text { Avg. }\end{array}$} & \multirow[b]{2}{*}{$\begin{array}{l}\text { State } \\
\text { Rank }\end{array}$} \\
\hline & 1997 & 1998 & 1999 & 2000 & 2001 & 2002 & 2003 & 2004 & 2005 & 2006 & 2007 & 2008 & & \\
\hline Oklahoma & 8.31 & 8.76 & 7.99 & 8.67 & 8.48 & 7.58 & 8.32 & 8.01 & 8.31 & 8.26 & 7.77 & 7.78 & 8.19 & 40 \\
\hline Oregon & 7.91 & 7.77 & 7.55 & 7.42 & 7.57 & 8.20 & 7.67 & 6.99 & 6.96 & 6.61 & 6.90 & 6.86 & 7.37 & 10 \\
\hline Pennsylvania & 8.44 & 7.91 & 6.86 & 7.28 & 7.50 & 7.49 & 7.17 & 6.99 & 7.15 & 7.03 & 7.29 & 7.24 & 7.36 & 9 \\
\hline Rhode Island & 8.45 & 7.36 & 6.70 & 7.29 & 7.84 & 5.91 & 6.54 & 6.57 & 7.12 & 7.69 & 7.28 & 8.68 & 7.29 & 6 \\
\hline South Carolina & 8.22 & 8.22 & 7.84 & 7.93 & 7.59 & 7.70 & 7.57 & 7.79 & 8.15 & 8.01 & 7.88 & 8.41 & 7.94 & 32 \\
\hline South Dakota & 8.78 & 8.28 & 8.03 & 7.70 & 7.69 & 7.12 & 7.00 & 6.81 & 7.21 & 7.33 & 7.35 & 7.39 & 7.56 & 21 \\
\hline Tennessee & 8.30 & 8.77 & 8.39 & 8.30 & 8.05 & 8.00 & 7.80 & 7.88 & 8.05 & 8.47 & 8.60 & 9.51 & 8.34 & 41 \\
\hline Texas & 8.23 & 8.17 & 7.59 & 7.91 & 8.65 & 7.60 & 8.26 & 7.90 & 8.91 & 9.54 & 8.52 & 8.89 & 8.35 & 42 \\
\hline Utah & 8.35 & 7.77 & 7.31 & 7.16 & 7.42 & 7.46 & 7.36 & 7.51 & 7.23 & 6.94 & 7.26 & 7.11 & 7.41 & 13 \\
\hline Vermont & 8.60 & 8.17 & 8.35 & 7.95 & 7.98 & 7.72 & 7.05 & 7.03 & 6.97 & 6.86 & 7.23 & 7.13 & 7.59 & 22 \\
\hline Virginia & 8.34 & 7.70 & 7.26 & 7.11 & 6.89 & 6.97 & 6.68 & 6.64 & 6.53 & 6.29 & 6.57 & 7.15 & 7.01 & 3 \\
\hline Washington & 8.09 & 7.79 & 7.45 & 7.40 & 7.34 & 7.54 & 7.48 & 7.24 & 7.04 & 6.99 & 6.72 & 6.87 & 7.33 & 8 \\
\hline West Virginia & 8.24 & 8.13 & 7.96 & 8.01 & 7.69 & 7.70 & 7.44 & 7.15 & 7.03 & 6.91 & 7.54 & 7.75 & 7.63 & 23 \\
\hline Wisconsin & 8.53 & 8.67 & 8.52 & 8.63 & 8.89 & 9.12 & 9.31 & 9.24 & 9.96 & 10.28 & 10.60 & 11.09 & 9.40 & 49 \\
\hline Wyoming & 8.96 & 8.72 & 8.17 & 7.99 & 7.79 & 7.91 & 7.52 & 7.26 & 6.93 & 6.30 & 5.98 & 5.97 & 7.46 & 17 \\
\hline U.S. Average & 8.40 & 8.20 & 7.81 & 7.73 & 7.80 & 7.62 & 7.51 & 7.34 & 7.58 & 7.78 & 7.90 & 8.27 & & \\
\hline
\end{tabular}


TABLE 2.6 - EXAMPLE OF ELECTRICITY CONSUMPTION METHOD CALCULATION:

ALABAMA'S SHADOW ECONOMY

1997

1998

1999

2000

2001

2002

2003

2004

2005

2006

2007

2008

Percent Growth in Shadow

Economy Size

(based on difference in

GDP and Electricity

Consumption growth rates)

$\begin{array}{llllllllllll}-0.03 & 0.06 & -0.04 & 0.02 & -0.09 & 0.03 & -0.01 & -0.01 & 0.03 & 0.06 & 0.04 & 0.08\end{array}$

Baseline Shadow Economy Estimate, 1996 (Schneider, 2010b): 8.85

Shadow Economy

Size, \% GDP

8.5

9.11

8.74

8.89

8.12

8.32

8.27

8.15

$8.39 \quad 8.88-9.26$

10.01

Notes: Schneider (2010b) provides shadow economy size estimates for 1995 and 1997. The 1996 baseline estimate used here is an average of the 1995 and 1997 values. Shadow economy growth rates represent growth from the previous year (e.g., 1997 growth rate is the growth in shadow economy size from the 1996 value). The 1997 shadow economy size (\% GDP) is calculated as the 1996 baseline estimate multiplied by the aggregate of 1 plus the 1997 growth rate, for example: $8.85 *(1-0.032)=8.57$; for $1998: 8.57 * 1.06=9.11$, and so on. 


\section{Appendix: Chapter 2}

Census Bureau's Classification Manual entry for "Protective Inspection and Regulation," (abbreviated by Campbell, et al., 2010)

"DEFINITION: Regulation and inspection of private establishments for the protection of the public or to prevent hazardous conditions NOT classified under another major function."

"EXAMPLES: Inspection of plans, permits, construction, or installations related to buildings, housing, plumbing, electric power plant sites, nuclear facilities, weights and measures, etc.; regulation of financial institutions, taxicabs, public service corporations, insurance companies, private utilities (telephone, electric, etc.), and other corporations; licensing, examination, and regulation of professional occupations, including health-related ones like doctors, nurses, barber, beauticians, etc.; inspection and regulation or working conditions and occupational hazards; motor vehicle inspection and weighing unless handled by a police agency; regulation and enforcement of liquor laws and sale of alcoholic beverages unless handled by a police department."

"EXCLUSIONS: Distinctive license revenue collection activities...; regulatory or inspection activities related to food establishments or to environmental health...; motor vehicle inspection, liquor law enforcement, and other regulatory type activities of police agencies...; regulatory and inspection activities related to other major functions, such as fire inspections, health permits, water permits, and the like..." (pp. 170-171) ${ }^{23}$

\footnotetext{
${ }^{23}$ The authors also offer a link to the manual: http://www.census.gov/govs/www/classfunc66.html
} 


\section{Chapter 3}

\section{Entrepreneurship, Corruption, and the Size of U.S. Underground Economies}

"In those corrupted governments where there is at least a general suspicion of much unnecessary expence, and great misapplication of the public revenue, the laws which guard it are little respected. Not many people are scrupulous about smuggling, when, without perjury, they can find any easy and safe opportunity of doing so."

Adam Smith, The Wealth of Nations, Book V, Chapter II, Part II, Article IV

\subsection{Introduction}

Institutions play an important role in the functioning of an economy. Studies show that high quality institutions promote economic growth and prosperity. Alternatively, where low quality institutions are in place, growth and prosperity are often diminished. Much of the empirical study of institutions and economic outcomes concentrates on measures of formal economic activity. However, where institutions make participation in the formal sector difficult, entrepreneurs will most often turn their productive efforts to underground markets (see deSoto, 1989, 2000;

Neuwirth, 2011). Thus, there exists a trade-off between formal and informal sector entrepreneurial activity that hinges, perhaps, on institutional quality. 
A recent study by Wiseman and Young (2012a) suggests that the effects of institutions on income levels are channeled through entrepreneurship. This is consistent with William Baumol's (1990) thesis in which he argues that entrepreneurs concentrate their efforts differently in different institutional environments. Specifically, Baumol contends that productive entrepreneurs exploit institutions that reward wealth-creation; unproductive entrepreneurs exploit institutions that reward rent-seeking behavior. Regardless of the majority entrepreneurial type at work in the formal sector, their decisions to pursue profits, be it in the Knightian (1921), Schumpeterian (1934, 1942), or Kirznerian $(1973,1979)$ entrepreneurial sense, begin with an assessment of the institutional framework. $^{24}$

Existing empirical studies of productive and unproductive entrepreneurial outcomes focus exclusively on the formal economy (see, e.g., Sobel, 2008; Wiseman and Young, 2012a, 2012b), and for good reason. Informal (or shadow) economic activity is deliberately undertaken in a way that escapes detection by public officials. ${ }^{25}$ Shadow economy participants' desire to remain undetected makes the researcher's task of measuring shadow activity particularly difficult. This means, too, that total entrepreneurial activity is at all times unobservable. Recent studies, however, have made data available at the U.S. state-level for both shadow economy size (Wiseman, 2012) and formal sector productive and unproductive entrepreneurial outcomes (Sobel, 2008; Wiseman and Young, 2012b). In light of this, I endeavor to take a closer look at the relationship between informal economies and Baumolian (1990) entrepreneurial outcomes.

\footnotetext{
${ }^{24}$ Frank Knight (1921) defended the entrepreneur as a person capable of pursuing profits while simultaneously assessing risk (measurable) and bearing psychological costs of uncertainty (immeasurable); Joseph Schumpeter $(1934,1942)$ viewed entrepreneurs as innovators who open new markets via the introduction of new goods or methods of production; Israel Kirzner $(1973,1979)$ stressed the importance of an acute alertness to profit opportunity as a defining characteristic of entrepreneurship.

${ }^{25}$ While this definition potentially includes both activity that is illegal generally and that which would be legal if not purposefully hidden - by this definition, dealers of illegal narcotics and under-the-table moonlighters both contribute to the underground economy - the empirical methodology used to estimate the shadow economy measures used in this study focuses more narrowly on otherwise legal market activity. More details follow in section 2.
} 
A question that comes to mind concerning Baumol's productive and unproductive entrepreneurial hypothesis is: What becomes of otherwise productive entrepreneurs who reside in (perhaps changing) institutional environments that largely (change to) reward unproductive activity? Productive entrepreneurs in the formal sector may of course choose to bear the full costs of an unfavorable institutional adjustment by continuing to behave the same as before. However, other plausible options include (1) productive formal activity in a new location: the entrepreneur may choose to migrate to other states or regions with institutions more favorable for wealth-creation; (2) unproductive formal activity: otherwise productive entrepreneurs re-focus some portion of their efforts to legal, unproductive activity (e.g., rent-seeking); (3) productive informal activity: entrepreneurs migrate to the underground economy to engage in wealthcreation; and (4) unproductive informal activity: entrepreneurs migrate to the underground economy to engage in some combination of more or less abrasive measures such as (i) thievery (more abrasive), and/or (ii) off-the-books transactions with corrupt public officials (less abrasive); the latter of the activities undertaken to secure privileges in the formal sector (see, e.g., Dreher and Schneider, 2010).

I focus primarily on option (3) and the less abrasive counterpart of option (4) in this study in order to examine more closely Baumol's theory. While (1), (2), and the more abrasive component of (4) are no less important considerations, a closer examination of these options is too broad to cover here.

Baumol's (1990) central hypothesis states that "it is the set of rules and not the supply of entrepreneurs or the nature of their objectives that undergoes significant changes from one period to another and helps to dictate the ultimate effect on the economy via the allocation of entrepreneurial resources" (p. 849, emphasis his). Here, I take the unchanging "nature of their 
objectives" to imply, first, the entrepreneur's profit motive, but also their means of acquiring profit. For the purpose of this study, I rest on the assumptions that, as the result of institutional change, entrepreneurs neither change in terms of supply (i.e., they do not likely migrate; they do not cease being entrepreneurial) nor do they entirely re-focus their efforts (e.g., productive entrepreneurs do not suddenly become strictly unproductive - formal or informal sector entrepreneurs). In other words, I contend that productive entrepreneurs will remain productive in the face of unfavorable institutional change, but that the portion of total productive entrepreneurship observed in the formal sector will fall as the rules of the game alter incentives to either (i) move productive efforts underground, and/or (ii) remain in the formal sector, but channel some effort into establishing relationships with bureaucratic authorities for the purpose of securing political favor. On the other hand, unproductive entrepreneurs will likely increase their unproductive behavior - in both the formal and informal sectors - under the same conditions.

In this paper I investigate the relationship between public official corruption, shadow economy size and formal sector entrepreneurship - both productive and unproductive - using cross-sectional data from the 48 contiguous U.S. states. In doing so, I make several novel contributions: (i) I examine the relationship between formal sector entrepreneurship and the shadow economy at the U.S. state-level; (ii) I attempt to address the primacy of the shadow economy as a channel through which corruption affects observed entrepreneurial outcomes. What I mean by shadow economy as a channel is that entrepreneurs make a choice between formal and informal sector participation based on institutional change (in this case changing levels of corruption). Shadow economy estimates serve as a proxy for that choice. Their decision will be revealed in observed (formal sector) entrepreneurial outcomes. Therefore, the choice of 
going formal versus informal (proxied for by shadow economy size) is a channel through which corruption affects formal entrepreneurial activity.

I tackle each of these tasks using a unique dataset constructed with U.S. state-level productive and unproductive entrepreneurship scores from Sobel (2008), and Wiseman and Young (2012b), and shadow economy estimates from Wiseman (2012). I discuss this data in the next section.

First, I establish that formal sector entrepreneurial activity is strongly linked to U.S. statelevel shadow economy size. A negative correlation between the shadow economy and productive entrepreneurship that takes place in the formal sector suggests that the above-mentioned assumptions are reasonable. If, as a state's shadow economy size increases, productive entrepreneurship in the formal sector decreases, it is plausible that otherwise productive entrepreneurs take seriously the option to engage in shadow economic activity. Of course, another option is for productive entrepreneurs to remain in the formal sector, but engage in more unproductive activity. This is an important consideration to keep in mind.

Second, I estimate the effects of shadow economy size on the separate formal sector productive, unproductive, and net entrepreneurial outcomes using ordinary least squares and a set of control variables. Since the shadow economy estimate, by construction, measures otherwise legal market activity ${ }^{26}$, expect a negative relationship between shadow economy size and formal productive entrepreneurship. In other words, if the shadow economy is growing, it is growing by way of productive activity taking place off-the-books. Alternatively, I expect that

\footnotetext{
${ }^{26}$ Public official bribery is at all times illegal. The shadow economy estimates, however, are measured in a way that does not distinguish between uses of income in the informal sector. This leads to some debate over the idea that the estimates capture only otherwise legal market activity (see, e.g., the appendix of Schneider, 2010a). For example, shadow incomes could very well fund some portion of the drug trade. The argument for these estimates capturing only otherwise legal market activity is founded in the fact that no measures of illegal activity (e.g., corruption, drug trade, etc.) are part of their construction (see Wiseman, 2012, section 2).
} 
formal unproductive entrepreneurship will correlate positively with shadow economy size. Intuitively, as institutions change to favor unproductive entrepreneurship in the formal sector, one would expect more of it. Again, in this case, I posit that even otherwise productive entrepreneurs may opt to engage in some observable unproductive activity.

Third, I question the primacy of underground economies in serving as a channel through which corruption affects observed (formal sector) entrepreneurship. And, I do so with the following theory in mind: as levels of corruption among public officials increase, entrepreneurs who may perceive bribe requests and other corrupt behavior as a tax on their productive efforts will exploit an option to engage in either the formal or informal economy. Their decision will be revealed in the portion of productive entrepreneurial activity that is observed in the formal sector. Alternatively, unproductive entrepreneurs may take advantage of corrupt officials to secure formal sector wealth transfers and other zero- or negative-sum redistributions via the shadow economy. Off-the-books currency transfers could feasibly serve as a means of securing these privileges (see, e.g., Dreher and Schneider, 2010). In other words, if the shadow economy serves as both a safe haven to which productive entrepreneurs may escape the pressures of corrupt officials, and a mechanism through which unproductive entrepreneurs gain formal sector privilege, then corruption should correlate with observable entrepreneurial outcomes through its effect on the shadow economy. I contend that if this is the case, then estimates of state-level corruption should serve as a strong and valid instrument for shadow economy size in a regression on observed entrepreneurial outcomes.

However, it is improbable that corruption affects observed productive (unproductive) entrepreneurship only through the shadow economy. Some entrepreneurs will not exploit the shadow economy at all. For example, it is possible that entrepreneurs will respond to changes in 
levels of corruption with adjustments made entirely in the formal sector (e.g., re-focusing their efforts between formal productive and formal unproductive activities). For this reason, instrument validity is a concern. Fortunately, validity is a null and therefore testable hypothesis.

The rest of the paper is organized as follows: section 3.2 discusses related studies; section 3.3 introduces the data and provides some motivation for the study with a cursory glance at the basic relationships between shadow economy size and entrepreneurship, and shadow economy size and corruption; section 3.4 provides methodology and results for a more formal empirical investigation of these relationships; section 3.5 concludes the study.

\subsection{Entrepreneurs and the Shadow Economy}

Recent studies suggest that entrepreneurs view the shadow economy as an escape from unfavorable, indeed corrupt, institutional environments (see, e.g., deSoto 1989, 2001; Neuwirth, 2011; Maloney, 2004). Pressures from corrupt officials only add to the burdens that entrepreneurs face when making decisions about their entrepreneurial pursuits. Katsios (2006), in a study of corruption in Greece, finds that "the shadow economy and the amount of corruption in Greece is closely connected with reflexes of the 'less privileged': the ones who are not willing, cannot afford or have no connections to central or local government bureaucrats[.]" Further, "[the less privileged] are systematically choosing the dark (shadow) side of the economy as a substitute for corruption (bribery), making the shadow economy complimentary to a corrupt state" (pp. 78).

Entrepreneurs take extraordinary risk in bringing new, innovative ideas or products to market. The entrepreneurial process is undoubtedly one of trial and error. According to Javanovic (1982, p. 649), "[f]irms learn about their efficiency as they operate in the industry. 
The efficient grow and survive; the inefficient decline and fail," often doomed by lack of foresight. Small firms especially experience extraordinarily high rates of failure (Maloney, 2004). These "trial" costs are not insignificant. Basic start-up costs alone make the shadow economy an attractive avenue for entrepreneurs to first try out their innovations, and avoid many costs associated with formal sector participation.

However, adding to information cost and general start-up costs in the formal sector are often costs associated with tax compliance, licensing, government social welfare programs, and the like. These costs often work to enhance the allure of the shadow economy for entrepreneurs (Maloney, 2004; Levenson and Maloney, 1996). Schneider et al. (2010) find, empirically, that for 162 (Eastern European, Central Asian, and high-income OECD) countries, increased burdens of the above-mentioned type are among the "driving forces of the shadow economy" (pp. 443). Similarly, for a panel of 50 U.S. states, Wiseman (2012) finds that larger size of government, tax and social welfare burdens, and lower levels of labor market freedom contribute to increased shadow economic activity.

Empirical studies of entrepreneurship and the U.S. shadow economy are scarce. Most relevant to my analysis, Estrin and Mickiewicz (2012) provide the first cross-country study, in which the U.S. is included, to examine the effect of shadow economy size on entrepreneurial entry (i.e. business start-ups) in the formal sector. Using individual-level data from the Global Entrepreneurship Monitor (GEM) and shadow economy estimates from Schneider and Buehn (2009), they find a negative correlation between shadow economy size and (formal) entrepreneurship.

Other studies document a link between corruption and the shadow economy (e.g., Dreher and Schneider, 2010; Johnson et al., 1997; Johnson et al. 1998a, 1998b). Probably most relevant 
to my study is the Dreher and Schneider (2010) study in which the authors posit two hypotheses concerning the relationship between corruption and the shadow economy, and find some empirical support for both. Their first hypothesis suggests that shadow economic activity and corruption act as compliments in places with low formal sector incomes. Intuitively, in low income places - typically exhibiting relatively higher levels of corruption - participants in the informal sector will be more likely to immerse themselves almost entirely in the underground. Moreover, shadow economies in these places, while comprising primarily of individuals and small firms, are more likely to include large firms. Dreher and Schneider claim that corrupt officials and evasive entrepreneurs are more likely to reinforce each other's' activity under such conditions.

Their second claim is that shadow economic activity and corruption act as substitutes in places with high formal sector incomes. Here, participants will be less likely to fully immerse themselves in the underground. Instead, they will work partially in the official economy and partially in the shadow economy. Large firms will operate almost entirely in the formal sector. Any informal interaction will usually result in an increase in formal activity - e.g., firms may bribe officials for large public works' contract awards. In other words, in high income formal economies, underground economy participants are more likely to engage in informal transactions primarily to secure the privilege to engage in more formal economic activity. In this case, an entrepreneur who catches wind of a corrupt official and exploits their misuse of power may leave the informal economy almost entirely to attend to work in the official sector.

Parts of both hypotheses, I think, are relevant here. Though, their second hypothesis applies more generally, as the U.S. certainly qualifies as a high-income nation. If, however, U.S. entrepreneurs can be categorized into high and low income groups, then perhaps both of Dreher 
and Schneider's hypotheses apply. One can imagine, for example, a low-income entrepreneur in the start-up phase of his endeavor (say, a construction company) finding that corruption among local public officials is incentive enough to operate his business almost entirely off-the-books. Though, as his business grows to a larger, high-income firm, remaining in the informal sector may become prohibitively costly. Perhaps his business grows such that he can now afford to (or can no longer afford not to) engage with corrupt officials for the purpose of securing formal sector privileges.

Finally, a small group of studies document a link between corruption and entrepreneurship (e.g., Tonoyan et al., 2010; Avnimelech et al., 2011). Avnimelech et al. (2010) examine the relationship between corruption (perception) levels and "productive" formal sector entrepreneurship using a unique cross-country dataset constructed from Linkedin. ${ }^{27}$ The authors define productive entrepreneurs as "all [Linkedin] members that defined themselves as founders [of a firm]" (pp. 12). They use the Transparency International (TI) Corruption Perceptions Index to capture country-level corruption. Their findings suggest a negative correlation between corruption and entrepreneurial outcomes.

The purpose of this paper is to more formally test the link between corruption, shadow economy size, and productive and unproductive entrepreneurial outcomes. I attempt to bring to light the importance of the shadow economy as both a potential option for productive entrepreneurs who desire to evade corrupt officials, and a place for unproductive entrepreneurs engaged with corrupt public officials to secure more formal sector privileges (e.g., wealth transfers, labor contracts, etc.). This attempt is based on the claim that if corruption affects entrepreneurial outcome through its effect on shadow economy size, then corruption should

${ }^{27}$ Linkedin is a social networking website designed to connect working professionals. Users create profiles that include information about past and present employment, including self-employment business ventures, education, etc. 
serve as a strong and valid instrument for shadow economy size in regressions on formal sector entrepreneurial outcomes.

\subsection{Measuring Corruption, Shadow Economy, and Entrepreneurship}

I begin by presenting a cursory glance at the U.S. state-level data on corruption, shadow economy size, and entrepreneurship that motivate this study. Corruption data come from the U.S. Department of Justice's Report to Congress on the Activities and Operations of the Public Integrity Section, 2010 and capture the annual number of corruption convictions of public officials in each state. Following Leeson and Sobel (2008), I divide the number of corruption convictions by each state's annual population statistics to arrive at a measure of corruption convictions per 100,000 residents. Corruption crimes include convictions for election-related crimes (vote fraud and campaign-financing crimes, etc.), and various crimes related to ,for example, bribery, embezzlement, unlawful insider deals with private vendors and other public officials, extortion, etc. Thus, corruption as it is captured in this data fits the more general definition of corruption often cited in the literature. That is, the abuse of public power for private gain (Dreher and Schneider, 2010). Additionally, this data differs from corruption data used in most other related studies in that it is observed (versus perceived) corruption.

Data for shadow economy size come from MIMIC model estimates provided in Wiseman (2012). The size of the shadow economy is represented as a proportion of state-level GDP. Wiseman's estimates are founded on methodology that considers multiple indicators and multiple causes (MIMIC) of shadow economic activity in a system of equations designed to estimate unobserved activity. MIMIC estimation is a commonly used methodology with roots in shadow economy estimation dating back to Frey and Weck-Hanneman (1984). Friedrich 
Schneider subsequently pioneered much of the work measuring the relationship between shadow economies and formal (and informal) institutions, including corruption. His work, spanning more than 25 years, has delivered fairly conclusive results; primarily in cross-country studies. There is consensus, for example, that shadow economy size is generally smaller in relatively high quality institutional environments. ${ }^{28}$

Wiseman (2012) estimates shadow economy size for the 50 U.S. states (excluding the District of Columbia) over the period 1997 to 2008. He finds that measures of government size, tax and social welfare burdens, labor market regulations, and intensity of regulation enforcement in the official sector are all statistically significant determinants of the underground economy. I use these estimates here to evaluate the relationships between corruption, shadow economy size, and formal sector entrepreneurship.

Entrepreneurship scores for each of the 48 contiguous U.S. states come from Wiseman and Young (2012b) and are based on Sobel's (2008) methodology. ${ }^{29}$ Productive entrepreneurship scores are based on per capita venture capital investments, patents per capita, the soleproprietorship growth rate, total establishment birth rates, and large (500 employees or more) establishment birth rates. Development of a productive entrepreneurship score based on several indicators differentiates this analysis from the broader, more general body of entrepreneurship literature. Many studies focus on self-employment alone as a proxy for entrepreneurship. ${ }^{30}$ However, Hurst and Pugsley (2011) use a variety of U.S. survey evidence to demonstrate that the self-employed do not fit common concepts of the entrepreneur. Specifically, they are not

\footnotetext{
${ }^{28}$ See, for example, some recent studies such as Dreher et al. (2009); Dreher and Schneider (2010); Torgler, et al. (2011); Schneider (2012); Buehn and Schneider (2012); Buehn (2011); Feld and Schneider (2010).

${ }^{29}$ For details see Sobel (2008, pp. 646-647; Appendix A). Also, since Sobel's study is limited to the 48 contiguous states, so, too, is this study.

${ }^{30}$ Recent examples using U.S. data include Hamilton (2000), Moskowitz and Vissing-Jørgensen (2002), Glaeser (2007).
} 
particularly innovative nor do their businesses tend to exhibit high rates of growth. ${ }^{31}$ Selfemployment may often also be indicative of poor economic conditions where the opportunity cost (in the form of available wage employment) is not high (Rissman, 2003). By focusing on multiple indicators of profit-seeking and innovative activity, a broad range of productive (formal sector) entrepreneurial activity is captured.

Unproductive entrepreneurship scores incorporate three measures of per capita political and lobbying establishments in a state's capital. These are based on the number of establishments in (i) SIC codes 8650 (political organizations), (ii) SIC codes 8650 and 8690 (membership organizations), and (iii) SIC codes 8650, 8690, and 8390 (social services organizations) (Sobel and Garrett, 2002). The unproductive entrepreneurship scores are also based on (100 minus) an index of liability system quality (the Harris Poll). Data for judicial system quality come from the U.S. Chamber of Commerce's survey-based State Liability Systems Ranking Study (2002-2008). Respondents for the survey were drawn from a nationally representative sample of senior attorneys at companies with revenues of at least $\$ 100$ million. Overall scores are based on a 100point scale (100=highest quality) and reflect attitudes and perceptions of state liability systems based on the following (Taylor, et al., 2002-2010): ${ }^{32}$

- $\quad$ Tort and Contract Litigation

- Treatment of Class Action Law Suits

- $\quad$ Punitive Damages

- $\quad$ Timeliness of Summary Judgement/Dismissal

- Discovery

- $\quad$ Scientific and Technical Evidence

- Judges' Impartiality and Competence

- Juries' Predictability and Fairness

\footnotetext{
${ }^{31}$ Indeed, Hurst and Pugsley present evidence that the self-employed do not tend to want to be innovative or grow their businesses considerably; rather, the non-pecuniary benefits of not working for someone else are their primary motivation for being self-employed.

${ }^{32}$ Since judicial quality data are provided only for years 2002 to 2008 , much of the study is limited to this period.
} 
Based on these, as the quality of judicial systems rise, judges become more competent, court processes take less time, enforcement is strict, and there is a higher likelihood of fines, etc. (hence, 100 minus this index value is employed to measure an increase in unproductive activity). States that have relatively low Harris Poll scores tend to have high rates of legal fraud and abuse in the areas of, e.g., workers compensation, class-action, and medical malpractice. All of these measures attempt to gauge the level of resources in a state that are being expended in legal and political processes rather than in productive market activities.

For both productive and unproductive scores, the constituent state-level variables are ranked from 1 through 48 from smallest to largest. A state's score is then the average of rankings across the constituent variables. ${ }^{33}$ Net entrepreneurship scores are calculated as the difference between productive and unproductive scores (productive - unproductive $=$ net).

Figure 3.1 illustrates the relationships between productive, unproductive, and net entrepreneurship scores and state-level shadow economy size. Shadow economy size is correlated significantly and negatively with both productive and net entrepreneurship scores (correlations are -10.997 and -16.070, respectively; both significant at the 1 percent level). Shadow economy size is correlated significantly and positively with unproductive entrepreneurship (the correlation is 5.073; significant at the 5 percent level). Intuitively, these raw correlations can be interpreted as the point-change in the relevant entrepreneurship score given a 1 percentage point increase in shadow economy size as a percent of GDP. For example, a

\footnotetext{
${ }^{33}$ For example, a state ranked 23, 45, 20, 25, and 38 in terms of, respectively, per capita venture capital investments, patents per capita, sole-proprietorship growth rates, establishment birth rates, and large establishment birth rates would have a productive entrepreneurship score of $(23+45+20+25+38) / 5=30.20$. For more detail on the construction of these scores, see Wiseman and Young (2012b) and Sobel (2008). Details on the underlying data for the entrepreneurship scores from Wiseman and Young (2012b) are provided in Table 4.1 (p. 94) located in Chapter 4.
} 
1 percentage point increase in shadow economy size is associated with an 11 point decrease in a state's productive entrepreneurship score, on average.

It is interesting to note that the correlation between shadow economy size and productive entrepreneurship is both economically and statistically more significant than the correlation between shadow economy size and unproductive entrepreneurship. Also, the effect of the shadow economy on net entrepreneurship is negative, suggesting a dominant, negative effect on productive entrepreneurship. Perhaps this result lends some support for the claim made in section 1 that the shadow economy is made up primarily of productive entrepreneurs engaging in otherwise legal market activity. Again, it is plausible that unproductive entrepreneurs, too, engage in informal markets along with corrupt officials for the purpose of securing official sector privileges, or that productive entrepreneurs re-focus some of their efforts to unproductive activity. The shadow economy has not yet been looked at in terms of a channel through which corruption affects these observed entrepreneurial outcomes. But, if that connection is made, the very basic results in Figure 3.1 suggest that perhaps more productive entrepreneurs are choosing the shadow economy option for productive informal purposes relative to those choosing to take advantage of the shadow economy in order to engage in more unproductive formal sector activity.

Figure 3.2 plots public official corruption convictions (per 100,000 pop.) against the entrepreneurship scores. The results are similar to those using shadow economy sizes. Corruption is significantly and negatively correlated with both productive and net entrepreneurship scores (correlations are -17.218 and -20.149; statistically significant at the 1 percent and 10 percent levels, respectively). Corruption is positively correlated with unproductive entrepreneurship (correlation is 2.931 ), but not in a statistically significant way (p-value $=0.667$ ) 
Figure 3.3 plots the relationship between shadow economy size and public official corruption. The relationship is positive (correlation is 1.021) and statistically significant at the 5 percent level.

Based on these basic correlations, in the next section I move on to regression analysis in which I examine these relationships more closely using additional controls. Controls include 2005 data from the U.S. Census Bureau on state population density, median age of the citizenry, percent of the population with at least a bachelor's degree, and percent of the population that is male. Summary statistics and data sources are provided in Table 3.1.

\subsection{Results}

Effects of Shadow Economy Size on Entrepreneurship

I begin with the following empirical framework:

$E S=\beta_{0}+\beta_{1}$ Shadow $+\beta_{2}$ Pop. Density $+\beta_{3}$ Median Age $+\beta_{4}$ College $+\beta_{5}$ Male $+\varepsilon$,

where ES represents productive, unproductive, and net entrepreneurship scores; Shadow represents shadow economy size (\% GDP). The remaining RHS control variables are 2005 estimates of population density, median age, percent of population with at least a bachelor's degree (College), and percent of the population that is male. $\beta_{1}$ is the coefficient estimate of interest.

Columns 1, 2, and 3 of Table 3.2 contain the results of OLS regressions from equation (3.1) using the productive, unproductive, and net entrepreneurship scores, respectively, as dependent variables. The signs remain unchanged from the correlations reported in Figure 3.1. Further, the effect of shadow economy size on each of the entrepreneurship scores appears to be both statistically and economically significant. Shadow economy size is significantly and 
negatively correlated with both productive (column 1) and net entrepreneurship (column 3)

scores (correlations are -7.189 and -15.046, respectively; both significant at the 1 percent level). Column 2 exhibits a positive correlation (7.857) between shadow economy size and unproductive entrepreneurship; statistically significant at the 1 percent level. Intuitively, these correlations suggest the approximate point-change in entrepreneurship scores given an increase in shadow economy size by a sample standard deviation (0.59). For example, column 1 suggests a sample standard deviation increase in shadow economy size is associated with about a 7 point decrease in productive entrepreneurship, on average.

The next step in the analysis approaches the question: does corruption affect entrepreneurship primarily through its effect on the shadow economy? To attempt an answer, I aim to test the claim that if corruption is related to entrepreneurial outcomes in this way, then corruption should serve as a strong and valid instrument for shadow economy size in an entrepreneurial outcome regression. For this, I turn to GMM estimation. First, however, it is worth checking the robustness of the OLS results reported above. Columns 4, 5, and 6 provide GMM estimations using the following identification strategy: (a) I assume that Pop. Density, Median Age, College, and Male are exogenous variables; and (b) I include the 2000 values of these same variables as additional instruments. With the 2005 values as exogenous regressors, it is plausible that the 2000 values are correlated with shadow economy size, but otherwise not correlated with the entrepreneurship scores. Using the 2000 values of the control variables as additional instruments also provides over-identifying restrictions that can be tested to evaluate instrument validity.

Columns 4 and 6 report point estimates for the effect of shadow economy size on productive and net entrepreneurship, respectively. Again, both estimates are negative 
(correlations are -15.634 and -23.969 , respectively) and statistically significant at the 1 percent level. Column 5 reports a positive and statistically significant point estimate for the effect of shadow economy size on unproductive entrepreneurship (correlation is 9.418 ; significant at the 5 percent level). It is worth noting here that GMM estimates suggest that the effect of shadow economy size on observed productive entrepreneurship is both statistically and economically more significant than the effect of shadow economy size on observed unproductive entrepreneurship. As with results reported in Figure 3.1, this adds additional support to my previous claim that the shadow economy is populated primarily with productive entrepreneurs. Columns 4 through 6 also report the " $1{ }^{\text {st }}$ stage" F-statistic (8.33) associated with a regression of Shadow on the instruments. The test rejects the null (instruments being jointly uncorrelated with Shadow) at conventional significance levels. Also reported are the p-values for the Sargen test of over-identifying restrictions J-statistics. Validity of the instrument set cannot be safely rejected in columns 4 and 6 (J-statistics are 0.514 and 0.240 , respectively). The Jstatistic for column 5, however, rests on the margin of rejection (J-statistic is 0.100$)$.

Based on these GMM results, the effect of shadow economy size on entrepreneurial outcomes illustrated in Figure 3.1 and Table 3.2 OLS regressions (columns 1-3) are robust. Next, I move on to examine the primacy of the shadow economy as a channel through which corruption affects entrepreneurship.

\section{Does Corruption Affect Entrepreneurship Primarily through the Shadow Economy?}

Recall the basic correlations reported in Figure 3.2. The relationship between public official corruption and both productive and net entrepreneurship scores is negative (-17.218 and -20.149, respectively) and statistically significant (at the 1 percent and 10 percent levels, respectively). 
The relationship between corruption and unproductive entrepreneurship is reported as positive (correlation is 2.931), but not significantly so.

The question that I ask here is: does corruption affect entrepreneurship through its effect on shadow economy size? To get at this I am going to study the strength and validity of corruption as an instrument for shadow economy size. If a strong and valid instrument, Corruption will be correlated with Shadow (strong), but otherwise uncorrelated with entrepreneurship scores (valid). In other words, if the shadow economy is the primary channel through which corruption indirectly affects entrepreneurship, then I expect that co-movements of corruption and entrepreneurship are a result of co-movements between corruption and shadow economy size. Again, it is improbable that corruption affects observed entrepreneurship only through the shadow economy. Fortunately, however, both instrument weakness and validity are testable hypotheses.

Table 3.3 reports results from GMM estimation of the productive, unproductive and net entrepreneurship scores when Corruption is added as an additional instrument variable. Adding Corruption as an instrument increases the absolute value of point estimates on Shadow for regression on both productive (from -15.634 to -16.286) and unproductive (from 9.418 to 9.485) entrepreneurship scores, relative to the corresponding regression in Table 3.2 (columns 4 and 5). The absolute value of Shadow point estimates on net entrepreneurship fall slightly from -23.969 to -23.219 . Statistical significance of the Shadow point estimates remain unchanged at the 1 percent, 5 percent, and 1 percent levels, respectively, for regressions on productive, unproductive, and net entrepreneurship.

Column 4 in Table 3.3 reports several tests evaluating Corruption as an instrument for Shadow. The t-statistic (2.54) is reported from a regression of Corruption on Shadow. The point 
estimate on Corruption is statistically significant marginally at the 1 percent level (p-value is 0.015). This alleviates concern about instrument strength. P-values from Sargen test J-statistics are reported at the bottom of columns 1-3 in Table 3.3. The over-identifying restrictions cannot be rejected at conventional levels of significance. I do not find strong evidence that Corruption is an invalid instrument.

\subsection{Conclusion}

This paper investigates the relationships between corruption (as a specific dimension of institutional quality), shadow economy size, and Baumolian entrepreneurial outcomes. The study is motivated by two basic questions: (1) what becomes of otherwise productive entrepreneurs who reside in (perhaps changing) institutional environments that largely (change to) reward unproductive activity? To date, research based on Baumol's (1990) theory only discusses entrepreneurial outcomes in terms of formal economic activity. However, a plausible assumption is that productive entrepreneurs faced with institutional roadblocks migrate to underground economies. To this end, I ask: (2) what role does the shadow economy play in sheltering productive entrepreneurs from poor institutional environments, specifically those with higher levels of public official corruption? Moreover, how does the entrepreneur's choice to exploit the shadow economy play a role in the relationship between public official corruption and observed entrepreneurial outcomes?

Using OLS regression analysis, I find that shadow economy size correlates negatively (positively) and in a statistically significant way with productive (unproductive) entrepreneurship. This finding, at least, supports the possibility of productive entrepreneurial 
migration to the shadow economy; and a support mechanism within the shadow economy for formal sector unproductive activity. Furthermore, these results are robust to GMM estimation. I approach question (2) above with both the OLS/GMM results and the following claim in mind: if corruption affects entrepreneurial outcomes through its effect on shadow economy size, then corruption should serve as a strong and valid instrument for shadow economy size in entrepreneurial outcome regressions. I present evidence that corruption is a strong instrument for shadow economy size; one for which validity cannot be rejected in regressions on productive, unproductive, and net entrepreneurship scores. However, I cannot safely assert that I find evidence of the shadow economy serving as a primary channel through which corruption affects observed entrepreneurial outcomes. Failure to reject validity of the corruption instrument is, at best, suggestive of the primacy of the entrepreneurial choice between formal and informal sector participation. 
FIGURE 3.1 - RELATIONSHIPS BETWEEN ENTREPRENEURSHIP SCORES AND SHADOW ECONOMY SIZE
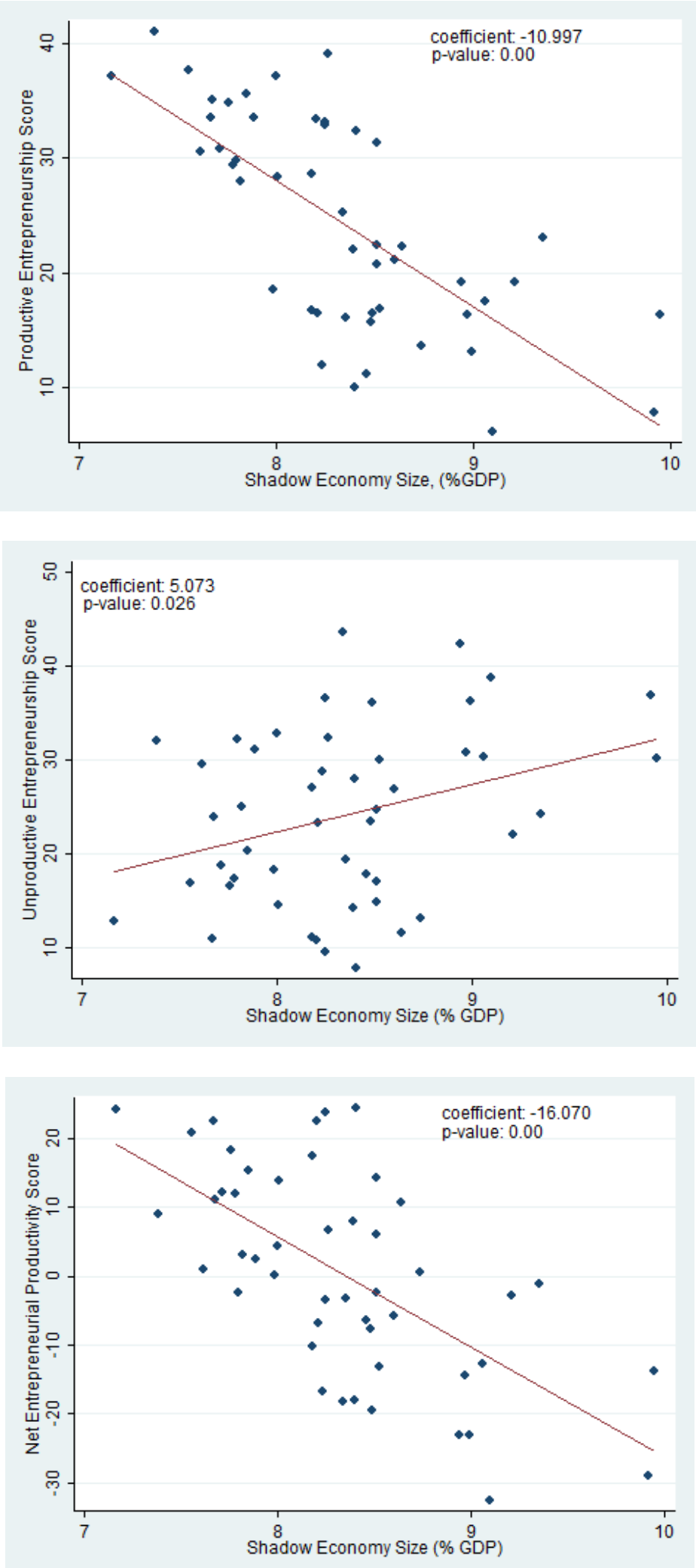
Figure 3.2 - RElationships BetweEn ENTREPRENEURShip SCORES AND PUbliC OfFicial Corruption
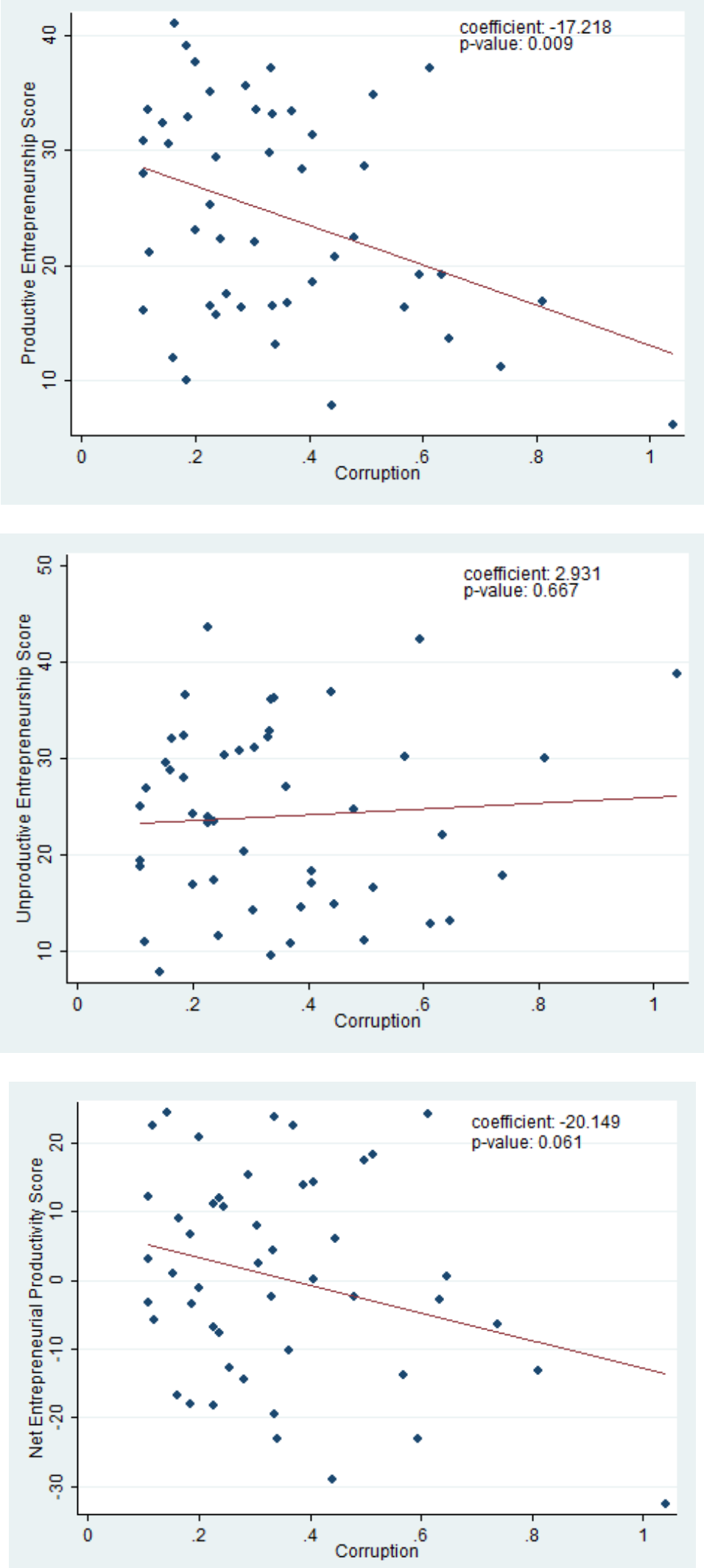
Figure 3.3 - Relationship Between Shadow Economy Size ANd PUblic OfFicial Corruption

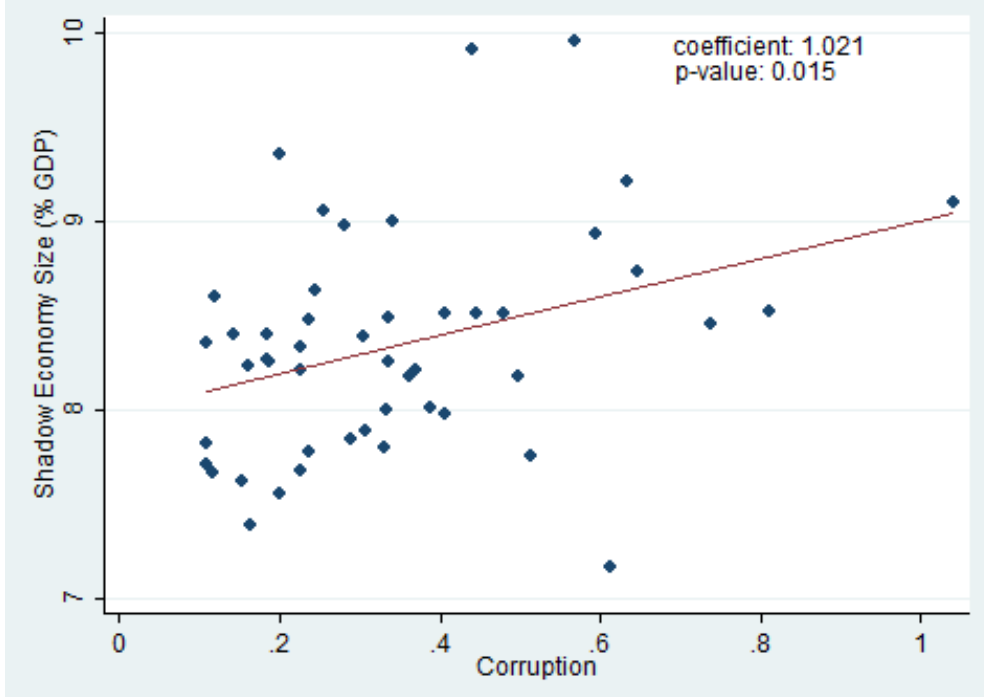


TABLE 3.1 - SUMMARY Statistics

\begin{tabular}{|c|c|c|c|c|c|c|}
\hline Variable & Data Source & Obs & Mean & $\begin{array}{l}\text { Std. } \\
\text { Dev. }\end{array}$ & Min. & Max. \\
\hline $\begin{array}{l}\text { Net Entrepreneurial } \\
\text { Productivity Score }\end{array}$ & Wiseman and Young (2012b) & 48 & 0.38 & 15.01 & -32.52 & 24.48 \\
\hline $\begin{array}{l}\text { Productive } \\
\text { Entrepreneurship Score }\end{array}$ & Wiseman and Young (2012b) & 48 & 24.38 & 9.34 & 6.21 & 41.06 \\
\hline $\begin{array}{l}\text { Unproductive } \\
\text { Entrepreneurship Score }\end{array}$ & Wiseman and Young (2012b) & 48 & 24.00 & 9.35 & 7.88 & 43.59 \\
\hline $\begin{array}{l}\text { Shadow Economy Size } \\
(\% \text { GDP })\end{array}$ & Wiseman (2012) & 48 & 8.34 & 0.59 & 7.17 & 9.95 \\
\hline Corruption (per 100,000) & $\begin{array}{l}\text { U.S. Department of Justice's Report to Congress on } \\
\text { the Activities and Operations of the Public Integrity } \\
\text { Section, } 2010\end{array}$ & 48 & 0.35 & 0.20 & 0.11 & 1.04 \\
\hline Pop. Density & Census Bureau & 48 & 192.51 & 260.42 & 5.45 & 1169.82 \\
\hline Median Age & Census Bureau & 48 & 36.59 & 2.07 & 28.01 & 40.63 \\
\hline Bachelor's +, \% & Census Bureau & 48 & 26.27 & 4.73 & 16.50 & 37.00 \\
\hline Male Pop., \% & Census Bureau & 48 & 49.25 & 0.65 & 48.35 & 50.89 \\
\hline
\end{tabular}


Table 3.2 - Regressions of Productive, UnProductive, AND Net ENTREPRENEURShIP

\begin{tabular}{|c|c|c|c|c|c|c|}
\hline & 1 & 2 & 3 & 4 & 5 & 6 \\
\hline & \multicolumn{3}{|c|}{ OLS } & \multicolumn{3}{|c|}{ GMM } \\
\hline & \multicolumn{3}{|c|}{$\begin{array}{c}\text { Dependent Variables: } \\
\text { Entrepreneurship Scores }\end{array}$} & \multicolumn{3}{|c|}{$\begin{array}{c}\text { Dependent Variables: } \\
\text { Entrepreneurship Scores }\end{array}$} \\
\hline Independent Variables & Productive & Unproductive & Net & Productive & Unproductive & Net \\
\hline Shadow & $\begin{array}{l}-7.189^{* * *} \\
(1.860)\end{array}$ & $\begin{array}{l}7.857^{* * * *} \\
(2.822)\end{array}$ & $\begin{array}{l}-15.046^{* * *} \\
(3.675)\end{array}$ & $\begin{array}{c}-15.634^{* * *} \\
(3.512)\end{array}$ & $\begin{array}{l}9.418^{* *} \\
(4.669)\end{array}$ & $\begin{array}{l}-23.969^{* * *} \\
(6.636)\end{array}$ \\
\hline Pop. Density & $\begin{array}{l}0.005 \\
(0.005)\end{array}$ & $\begin{array}{c}0.009 \\
(0.008)\end{array}$ & $\begin{array}{c}0.004 \\
(0.010)\end{array}$ & $\begin{array}{l}-0.003 \\
(0.003)\end{array}$ & $\begin{array}{c}0.011 \\
(0.010)\end{array}$ & $\begin{array}{l}-0.013 \\
(0.011)\end{array}$ \\
\hline Median Age & $\begin{array}{l}-1.550^{* * * *} \\
(0.471)\end{array}$ & $\begin{array}{l}-0.155 \\
(0.714)\end{array}$ & $\begin{array}{l}-1.395 \\
(0.930)\end{array}$ & $\begin{array}{l}-1.301^{* *} \\
(0.567)\end{array}$ & $\begin{array}{c}0.169 \\
(0.580)\end{array}$ & $\begin{array}{l}-1.630^{* *} \\
(0.698)\end{array}$ \\
\hline College & $\begin{array}{l}0.560^{* *} \\
(0.239)\end{array}$ & $\begin{array}{c}0.059 \\
(0.363)\end{array}$ & $\begin{array}{c}0.501 \\
(0.473)\end{array}$ & $\begin{array}{c}0.285 \\
(0.284)\end{array}$ & $\begin{array}{l}-0.047 \\
(0.368)\end{array}$ & $\begin{array}{c}0.111 \\
(0.544)\end{array}$ \\
\hline Male & $\begin{array}{l}-0.426 \\
(1.855)\end{array}$ & $\begin{array}{l}4.962^{*} \\
(2.815)\end{array}$ & $\begin{array}{l}-5.387 \\
(3.666)\end{array}$ & $\begin{array}{l}-3.424^{*} \\
(2.073)\end{array}$ & $\begin{array}{l}6.579^{* * *} \\
(2.360)\end{array}$ & $\begin{array}{l}-9.798^{* * * *} \\
(3.469)\end{array}$ \\
\hline \multicolumn{7}{|l|}{ Statistics } \\
\hline $\begin{array}{l}\text { Obs. } \\
\mathrm{R}^{2}\end{array}$ & $\begin{array}{c}48 \\
0.642\end{array}$ & $\begin{array}{c}48 \\
0.178\end{array}$ & $\begin{array}{c}48 \\
0.459\end{array}$ & 48 & 48 & 48 \\
\hline & & & $\begin{array}{l}\left.\text { F-stat ( } 1^{\text {st }} \text { Stage }\right): \\
\text { J-stat test p-value: }\end{array}$ & $\begin{array}{c}8.33^{* * * *} \\
0.514\end{array}$ & $\begin{array}{c}8.33^{* * *} \\
0.100\end{array}$ & $\begin{array}{l}8.33^{* * *} \\
0.240\end{array}$ \\
\hline
\end{tabular}

Notes: Standard deviations are in parentheses below parameter estimates. *, **, and *** denotes significance at the 10 percent, 5 percent, and 1 percent levels, respectively. Shadow, Pop. Density, Median Age, College, and Male are assumed exogenous and 2000 values of those variables are used as additional instruments. F-stats are from regressions of Shadow on IVs. 
Table 3.3 - Regressions of Productive, UnProductive, ANd Net EnTREPRENEURShIP WITH CORRUPTION IV

\begin{tabular}{|c|c|c|c|c|c|}
\hline & \multicolumn{3}{|c|}{ GMM: with Corruption IV } & & \\
\hline & \multicolumn{3}{|c|}{$\begin{array}{c}\text { Dependent Variables: } \\
\text { Entrepreneurship Scores }\end{array}$} & & \\
\hline $\begin{array}{l}\text { Independent } \\
\text { Variables }\end{array}$ & Productive & Unproductive & Net & & \\
\hline Shadow & $\begin{array}{c}-16.286^{* * *} \\
(3.219)\end{array}$ & $\begin{array}{l}9.485^{* *} \\
(4.431)\end{array}$ & $\begin{array}{c}-23.219^{* * *} \\
(5.917)\end{array}$ & F-stat $\left(1^{\text {st }}\right.$ Stage $)$ & $7.24^{* * * *}$ \\
\hline Pop. Density & $\begin{array}{l}-0.003 \\
(0.004)\end{array}$ & $\begin{array}{c}0.011 \\
(0.009)\end{array}$ & $\begin{array}{l}-0.012 \\
(0.011)\end{array}$ & T-stat: Shadow on Corruption: & $2.54^{* *}$ \\
\hline Median Age & $\begin{array}{l}-1.281^{* *} \\
(0.597)\end{array}$ & $\begin{array}{c}0.161 \\
(0.580)\end{array}$ & $\begin{array}{l}-1.624^{* *} \\
(0.691)\end{array}$ & & \\
\hline College & $\begin{array}{c}0.243 \\
(0.272)\end{array}$ & $\begin{array}{l}-0.045 \\
(0.368)\end{array}$ & $\begin{array}{l}0.145 \\
(0.521)\end{array}$ & & \\
\hline Male & $\begin{array}{l}-3.705^{*} \\
(2.005)\end{array}$ & $\begin{array}{l}6.548^{* * *} \\
(2.302)\end{array}$ & $\begin{array}{l}-9.403^{* * *} \\
(3.143)\end{array}$ & & \\
\hline \multicolumn{4}{|l|}{ Statistics } & & \\
\hline $\begin{array}{r}\text { Obs. } \\
\text { J-stat test p-value: }\end{array}$ & $\begin{array}{c}48 \\
0.660\end{array}$ & $\begin{array}{c}48 \\
0.110\end{array}$ & $\begin{array}{c}48 \\
0.377\end{array}$ & & \\
\hline
\end{tabular}

Notes: Standard deviations are in parentheses below parameter estimates. *,**, and *** denotes significance at the 10 percent, 5 percent, and 1 percent levels, respectively. Shadow, Pop. Density, Median Age, College, and Male are assumed exogenous and 2000 values of those variables are used as additional instruments. F-stats are from regressions of Shadow on IVs. 


\section{Chapter 4}

\section{Religion: Productive or Unproductive?}

"Ideas, organized ideologies, and even religious zealotry play major roles in shaping societies and economies."

Douglass North - Institutions, Institutional Change and Economic Performance, Chapter 5, Part IV

\subsection{Introduction}

What is the relationship between individuals' religiosity and their entrepreneurial activity? While this and related questions have long been pondered, perhaps most famously in Max Weber's (1905) The Protestant Ethic and the Spirit of Capitalism, it is the subject of only a few modern empirical studies. ${ }^{34}$ For example, based on individual-level data from India, Audrestch et al. (2007) find that Islam and Christianity tend to encourage entrepreneurship while Hinduism tends to discourage it. On the other hand, based on a panel of individuals from New Zealand, Carwell and Rolland (2007) find that non-Christian groups tend to be more entrepreneurial than Christians.

\footnotetext{
${ }^{34}$ For a review of history of thought on the economics of religion, as well as contemporary studies, see Iannaccone (1998). Regarding Weber, Tawney (1922) and Samuelsson (1961) are excellent examples of empirical refutations of his thesis regarding the Industrial Revolution and modern capitalist society.
} 
However, existing studies have not explicitly considered Baumol's (1990) thesis concerning productive versus unproductive entrepreneurial activity. Regardless of whether they are conceived of as risk-bearers (Knight, 1921), exceedingly creative individuals (Schumpeter, 1934), or those alert to hitherto unnoticed profit opportunities (Kirzner, 1973), entrepreneurs face decisions about whether to pursue wealth-generating activities or, alternatively, to engage in rent-seeking or outright theft. Their choices will largely be a function of the institutions - the "rules of the game" (North, 1990, p. 3) - within which they make those decisions. Religion represents one subset of those institutions.

There are numerous ways in which religious organizations and belief systems can shape the absolute and relative incentives to undertake productive and unproductive activities. For example, if a religion stigmatizes the accumulation of wealth and elevates the priority of the poor, then this may legitimize the redistributive use of political processes relative to innovative market activity. Alternatively, a religion may foster something along the lines of a "protestant ethic" (Weber, 1905) where individual industry is evidence of one's salvation. More generally, if a religion makes the present value of activity in this world seem small relative to that of the eternal hereafter, then this may dampen an individual's incentives to undertake any type of entrepreneurial activity.

For those individuals relatively prone to entrepreneurial activities, or who have relatively high endowments of entrepreneurial skills, religion can create costly obligations on time and other resources. Time spent in church is time that, by definition, is not spent on entrepreneurial activity; so is time spent in prayer. Income that flows into church coffers is income that does not flow into business ventures. Furthermore, given religious obligations on time and other 
resources, whether individuals substitute away relatively more from productive or unproductive activities is again a function of the incentives embodied in the religion.

In this paper we take Baumol seriously and explore the relationship between religion and entrepreneurship - both productive and unproductive - in data from the cross-section of contiguous U.S. states. There are only a handful of studies of religion and entrepreneurship based on U.S. data to begin with. Dodd and Gotsis (2007) examine survey data to explore whether individuals' religious concerns temper their motive to maximize profits. Radmard (2012) uses county level data to analyze whether the percent of a population belonging to a religious congregation correlates with self-employment and small firm growth. ${ }^{35}$ None of these studies make a distinction between productive and unproductive entrepreneurship. We do so using productive and unproductive entrepreneurship scores based on Sobel's (2008) methodology and updated using data from the 2002 to 2008 period.

In measuring "religion" we attempt to break this institutional catch-all down into several of its formal and informal elements. We use data not only on religious affiliation and church attendance, but also on the importance that individuals place on religion in general, their stated belief in God, and the frequency with which they pray. Furthermore, we explicitly account for the percent of individuals who self-report as atheist and/or agnostic. These are individuals who, more than simply not attaching themselves to a particular religious sect, explicitly express a general lack of belief, or even disbelief. Agnosticism and/or atheism may be associated with more self-interested behavior; they may also make entrepreneurial activities less costly in lieu of religious obligations.

\footnotetext{
${ }^{35}$ Radmard exploits the large number of county observations to test for spatial autocorrelation and finds that congregation membership has spillover effects to entrepreneurship in neighboring counties. However, Radmard does not clearly describe the channels through which these effects might operate.
} 
We organize the rest of the paper as follows. Section 4.2 contains a review of some related literature on religion and economic outcomes. We describe our data in section 4.3. Results of our regression analysis are to be found in section 4.4 and the paper is wrapped up with concluding discussion in section 4.5 .

\subsection{Related Studies}

As discussed above, the relationship between religion and entrepreneurship, specifically, has not been the focus of very many recent studies. However, several recent studies examine, more generally, the relationships between religion, institutions, and economic growth.

Robert Barro and Rachel McCleary are at the forefront of this literature. Using crosscountry data, Barro and McCleary (2003) find that religious beliefs - in particular, a belief in the existence of heaven and hell - are associated with higher rates of per capita income growth. However, they also find that church attendance negatively affects growth. In the authors' own words, "growth depends on the extent of believing relative to belonging" (p. 760). The data that we use in this paper allows us to evaluate Barro and McCleary's conclusion in regards to entrepreneurial activity in the U.S., estimating the effects of belief and belonging separately.

Complementing their earlier paper, McCleary and Barro (2006) investigate the effect of both economic development and institutions on religiosity. They conclude that the level of economic development is indeed a determinant of religiosity. Also, religiosity tends to fall with the extent of government regulation of religious activities. Their findings suggest that, in our analysis of religion's influence on entrepreneurship, controlling for income levels will be desirable. Also, even though the formal regulation of religion across U.S. states is minimal due 
to the first amendment of the federal constitution, we will control for a measure of institutional quality.

There has been relatively little empirical analysis of the channels through which religiosity affects economic growth (e.g., Audretsch et al., 2007; Carswell and Rolland, 2007). ${ }^{36}$ Here, we explore one potential channel though which religiosity may affect growth: entrepreneurship. Numerous studies document a positive relationship between entrepreneurial activity and economic growth (e.g., Zacharakis et al., 2000; Baumol, 2002; Baumol et al., 2007; Audretsch et al., 2006). Furthermore, Audrestch et al. (2007) considers the influence of religion on individual decisions to undertake entrepreneurial activity (measured by self-employment) in a cross-country study. They find that certain religions - e.g., Islam and Christianity - tend to encourage entrepreneurship, while others - e.g., Hinduism - discourage it. In a similar study, Carswell and Rolland (2007) find (for a New Zealand panel) that non-Christian groups tend to be more entrepreneurial than Christians.

The main contribution of this paper is to extend the definition of entrepreneurship across a platform of both productive and unproductive activity and examine religion in this context. Baumol (1990) offered the hypothesis that different institutions, depending on the incentives they embody, largely determine whether entrepreneurs will focus their efforts on productive or unproductive activities. Where institutions create relatively large rewards to rent-seeking behavior, entrepreneurs will focus their efforts primarily on unproductive activities. On the other hand, where institutions primarily support wealth-generating activity, productive entrepreneurs will flourish. Sobel (2008), Hall and Sobel (2008), and Wiseman and Young (2012) provide

\footnotetext{
${ }^{36}$ Our literature review focuses on econometric studies. Alternatively, Kuran (2011) is an excellent example of a comprehensive history relating religious institutions - in particular, Islamic Law - to secular institutions and economic development from medieval times forward.
} 
evidence supporting Baumol's hypothesis using U.S. data. To our knowledge we are the first to evaluate the Baumol hypothesis in regards to religious institutions in the U.S.

\subsection{Data on Belief, Belonging, and Entrepreneurship}

We begin by presenting some very basic looks at the U.S. state-level data on religion and entrepreneurship that we use in this study. Religion data are collected from three sources: (1) the Pew Forum's 2007 US Religious Landscape Survey ${ }^{37}$; (2) the Gallup Poll's 2004 and 2008 State of the States surveys ${ }^{38}$; and (3) the U.S. Census Bureau's 2000 and 2010 U.S. Religion Census: Religious Congregations \& Membership Study. ${ }^{39}$ The Pew belief measures capture the importance of religion, frequency of prayer, and belief in God; the Pew Forum also provides data on the percent of a state's population that attend religious services weekly. The Gallup affiliation data include the percent of states' populations that are Protestant, Catholic, or Atheist/Agnostic. The U.S. Census Bureau reports a measure of each state's Christian adherents ${ }^{40}$ as a percent of the total state population.

Entrepreneurship scores for each of the 48 contiguous U.S. states are based on Sobel's 2008 methodology. ${ }^{41}$ Sobel uses data from 1995 to 2002 and we update his scores using data from 2002 to 2008. The scores are then based on averages of data that are generally centered on

\footnotetext{
${ }^{37} \mathrm{http}: / / \mathrm{www}$.pewforum.org/Datasets: Importance of religion is expressed as percent of state population who say religion is very important in their lives; frequency of prayer is expressed as percent of state population who say they pray at least once a week; belief in god is expressed as percent of state population who say they believe in God with absolute certainty; worship service attendance is expressed as percent of state population who say they attend religious service at least once a week.

${ }^{38} \mathrm{http} / / / \mathrm{www}$. gallup.com/poll/12091/tracking-religious-affiliation-state-state.aspx\#2

${ }^{39} \mathrm{http}: / / \mathrm{www} . c e n s u s . g o v / c o m p e n d i a /$ statab/cats/population.html

40 "Christian church adherents were defined as 'all members, including full members, their children and the estimated number of other regular participants who are not considered as communicant, confirmed or full members"” (http://www.census.gov/compendia/statab/cats/population/religion.html).

${ }^{41}$ For details see Sobel (2008, pp. 646-647; Appendix A).
} 
the year 2000. They represent average levels of entrepreneurial activity in a state over a fourteen year period.

Productive entrepreneurship scores are based on per capita venture capital investments, patents per capita, the self-proprietorship (self-employment) growth rate, establishment birth rates, and large (500 employees or more) establishment birth rates. Numerous studies focus on self-employment alone as a proxy for entrepreneurship. ${ }^{42}$ However, Hurst and Pugley (2010) use a variety of U.S. survey evidence to demonstrate that the self-employed do not fit common concepts of the entrepreneur. Specifically, they are not particularly innovative nor do their businesses tend to exhibit high rates of growth. ${ }^{43}$ Self-employment may often also be indicative of poor economic conditions where the opportunity cost (in the form of available wage employment) is not high (Rissman, 2003). By focusing on multiple indicators of profit-seeking and innovative activity we hope to capture a broad range of productive entrepreneurial activity. Also, since we look at averages over several years, we hopefully avoid short-run countercyclical self-employment fluctuations that are not indicative of entrepreneurism.

Unproductive entrepreneurship scores incorporate three measures of per capita political and lobbying establishments in a state's capital. These are based on the number of establishments in (i) SIC codes 8650 (political organizations), (ii) SIC codes 8650 and 8690 (membership organizations), and (iii) SIC codes 8650, 8690, and 8390 (social services organizations) (Sobel and Garret, 2002). The unproductive entrepreneurship scores are also based on (100 minus) an index of liability system quality. The latter is the Harris Poll published by the Institute for Legal Reform and the U.S. Chamber of Commerce in its State Liability Systems Ranking. The Harris

\footnotetext{
${ }^{42}$ Recent examples using U.S. data include Hamilton (2000), Moskowitz and Vissing-Jørgensen (2002), Glaeser (2007).

${ }^{43}$ Indeed, Hugh and Pugley present evidence that the self-employed do not tend to want to be innovative or grow their businesses considerably; rather, the non-pecuniary benefits of not working for someone else are their primary motivation for being self-employed.
} 
Poll is an index of judicial quality on a 100 point scale. (Hence we take 100 minus this value.) States that have relatively low Harris Poll scores tend to have high rates of legal fraud and abuse in the areas of, e.g., workers compensation, class-action, and medical malpractice. All of these measures attempt to gauge the level of resources in a state that are being expended in legal and political processes rather than in productive market activities.

Table 4.1 details the underlying data for the entrepreneurship scores. For both productive and unproductive scores, the constituent state-level variables are ranked from 1 through 48 from smallest to largest. A state's score is then the average of rankings across the constituent variables ${ }^{44}$ This index classification system (a Borda count) normalizes all of the constituent variables and weights all of the equally. Note that, for example, in regards to the per capita establishment variables (i), (ii), and (iii) in the unproductive entrepreneurship score, utilizing a Borda count does not double or triple count constituent SIC industry variables. Rather, it takes an agnostic stance on whether (i), (ii), or (iii) is a better measure, equally weighting each state's rank for each measure in the ultimate unproductive entrepreneurship score. Finally, a state's net entrepreneurship score is then its productive entrepreneurship score minus its unproductive entrepreneurship score.

For some initial perspective on the relationships between our dependent and independent variables of interest, we turn to Figures 4.1 through 4.4. All of these scatters are, of course, indicative of simple bivariate correlations and cannot be taken too seriously. However, we do here discuss some plausible reasons that they manifest. This provides some intuitive motivation before moving on to more formal econometric analysis where the question of these correlations' robustness will be at the fore.

\footnotetext{
${ }^{44}$ For example, a state ranked 23, 45, 20, 25, and 38 in terms of, respectively, per capita venture capital investments, patents per capita, sole-proprietorship growth rates, establishment birth rates, and large establishment birth rates would have a productive entrepreneurship score of $(23+45+20+25+38) / 5=30.20$.
} 
Figure 4.1 presents scatter plots of worship service attendance rates against the productive, unproductive, and net entrepreneurship scores. ${ }^{45}$ Productive and net entrepreneurship scores are both negatively correlated with worship service attendance. (The correlations are 0.385 and -0.667 , respectively; both significant at better than the 5 percent level.) Unproductive entrepreneurship scores are correlated positively with attendance. (The correlation is 0.282 and is significant at the 10 percent level.) Barro and McCleary's (2003) cross-country analysis found that church attendance was associated with less economic growth and conjectured: "We think that this negative effect reflects the time and resources used by the religion sector as well as adverse effects from organized religion on economic regulation - for example, restrictions on markets for credit and insurance" (p. 3). The productive entrepreneurship correlation is consistent with an allocation of scarce resources toward religious activities and away from entrepreneurial ones. Regarding the significant positive correlation between attendance and unproductive entrepreneurship, religion may promote decreases in institutional quality generally, leading to greater opportunities for rent-seeking. It will be imperative in our more formal analysis, then, to control for general institutional quality. Another possibility, inconsistent with Barro and McCleary's conjecture, is that religion may lead individuals to impose costs on others (via regulations on market activity) for the sake of their own (spiritual) gains. ${ }^{46}$

It is interesting to note that attendance's correlation with productive entrepreneurship is both statistically and economically more significant than its correlation with unproductive

\footnotetext{
${ }^{45}$ The results are limited to 39 states. Both Sobel's (2008) scores and our more recent estimates cover only 48 states (exclude Alaska, District of Columbia, and Hawaii). Additionally, the Pew study combines, in several cases, two contiguous states to provide a single score for both. For this reason, the following states are also excluded: Connecticut, Maryland, Montana, New Hampshire, North Dakota, Rhode Island, South Dakota, Vermont, and Wyoming.

46 "Blue Laws" come to mind here - e.g., restrictions on Sunday retail activity. Alcohol prohibition - enacted by the 18th Amendment to the U.S. Constitution; repealed by the 21st - itself was the result of lobbying pressures from certain religious groups - specifically, Protestant missionary groups and the Woman's Christian Temperance Union (Harris, 2004).
} 
entrepreneurship. Also, the effect on net entrepreneurship is negative, suggesting that the negative effect on productive entrepreneurship dominates. Possibly relevant to this is the fact that a story of "the time and resources used by the religion sector" is apparently relevant to unproductive as well as productive entrepreneurial activities. (More time in church is less time available for either type of activity.) A positive effect of religion on unproductive entrepreneurship associated with institutional quality might be offset (at least in part) by the straightforward opportunity costs of being religious.

Worship attendance is a measure of religious belonging; what about religious beliefs?

Figure 4.2 plots belief in God measures against the entrepreneurship scores. The results are similar to those using church attendance. Productive and net entrepreneurship scores both correlate negatively with belief in God. (The correlations are -0.484 and -0.745 , respectively; both significant at better than the 1 percent level.) The correlation between unproductive entrepreneurship and belief is positive (0.261) but not statistically significant (p-value $=0.122$ ). The estimated relationships are also similar when considering measure of the frequency of prayer (Figure 4.3) or the importance of religion (Figure 4.4) measures. ${ }^{47}$ Unlike McCleary and Barro (2006) who report different effects on economic outcomes associated with religious belief versus belonging measures, our first cursory look at the data suggests no such distinction when it comes to productive and unproductive entrepreneurship.

Before moving onto our regression analysis, we mention the additional controls that we will incorporate in that analysis. Importantly, we include a state's (average of 2000 and 2005) Economic Freedom of North America (EFNA) score from the Fraser Institute (Karabegović et

\footnotetext{
${ }^{47}$ Additionally, similar results are derived from the raw correlations between the entrepreneurship scores and the various affiliation data from the Gallup Poll and U.S. Census Bureau, with one exception: Atheist/Agnostic affiliation correlates positively with productive and net entrepreneurship scores, and correlates negatively with unproductive entrepreneurship.
} 
al., 2006). The EFNA scores rank U.S. states on a scale of 1 to 10 , separately, for three areas of economic freedom: size of government, takings and discriminatory taxes, and labor market freedom. A higher score indicates more freedom (i.e., respectively, smaller government, fewer and lower taxes, and less restricted labor markets). The comprehensive EFNA score is the average score across constituent areas. Another important control variable is a state's (log) GDP per capita. (We again use the average of 2000 and 2005 values.) This is a proxy for a state's relative level of economic development. As suggested by McCleary and Barro (2006), the level of economic development may be an important determinant of religiosity. Omitting it from entrepreneurship regressions could then lead to biased coefficient estimates on religiosity. As additional controls we include, using data from the U.S. Census Bureau, a state's population density and median citizen's age; also the percent of its population with a bachelor's degree worth or more of education, and the percent of its population that is male. Summary statistics and sources for all variables used can be found in Table 4.2.

\subsection{Results}

We run regressions of each entrepreneurial score (productive, unproductive, and net) on (1) a religion variable of interest and (2) a standard set of controls: (log) GDP per capita, EFNA, population density, median age, percent of the population with a bachelor's degree or more, and the percent of the population that is male. The one-religion-variable-at-a-time approach is motivated by the fact that we are somewhat limited in terms of degrees of freedom (based on only $n=48$ ) and, also, there is substantial collinearity among the religion variables.

Our religion variables are broken down into two groupings of four. All variables are in terms of percentages of a state's population. First, there are religiosity measures: regular 
attendance of religious services, belief in God with absolute certainty, prayer at least once a week, and importance of religion described as "very". Second, there are affiliation variables: total (Christian) adherents, protestant, catholic, and atheist/agnostic. The last of these variables actually expresses the percent of the population that decidedly categorizes themselves as having no religious adherence. Presumably, such individuals do not pray or hold religion of any notable importance in their lives; they rank low in terms of both belief and belonging.

Tables 4.3, 4.4, and 4.5 contain results for productive, unproductive, and net entrepreneurship scores, respectively. Each table has eight columns of results; in a given table, each individual column is associated with a specific religion variable. In the productive entrepreneurship score regressions (Table 4.3) the coefficient estimates on the first seven religion variables are negative, and four of those estimates are statistically significant at the 5 percent level or better (attendance, prayer, importance, and total adherents). In terms of belief versus belonging, both seem to be quantitatively meaningful. If a state's attendance increases by a sample standard deviation (8.87), this increase is associated with about a 4 point decrease in the state's productive entrepreneurship score. The effect is slightly larger for total adherents where a sample standard deviation increase (10.18) is associated with an almost a 5 point decrease in a state's productive entrepreneurship score. While a one sample standard deviation increase in belonging-type prayer variable (2.39) is associated with just over a 2 point decrease in a state's productive entrepreneurship score, the effect is larger for importance. A sample standard deviation increase (6.20) is associated with about a 4 point decrease in a state's productive entrepreneurship score.

Interestingly, the percent of the population that is atheist/agnostic is positively and significantly related to a state's productive entrepreneurship score. The estimated effect of 
changes in the atheist/agnostic share of the population is (in absolute value) comparable to that of attendance and importance. A sample standard deviation increase in this atheist/agnostic (3.26) is associated with about a 4 point increase in a state's productive entrepreneurship score. Because the score is a Borda count, another approximate interpretation of the size of such an effect is that a state would increase its rank among other states by 4 spots.

Table 4.4 reports the results based on using unproductive entrepreneurship scores as the dependent variable. While measures of both belief and belonging appear to be associated with decreases in productive entrepreneurship, this could be because religiosity imposes opportunity costs on time and other resources that could be employed in productive entrepreneurial endeavors; however, it could also be because of increases in the relative net benefits to rentseeking. In our data, the evidence for the latter story is somewhat weak. Total adherents is positively related to states' unproductive entrepreneurship scores, and the effect is statistically significant at the one percent level. The effect is economically not negligible. A sample standard deviation increase in total adherents is associated with just under a 4 point increase in a state's unproductive entrepreneurship score. However, none of the other religion variables, including atheist/agnostic, enter significantly into a regression of state unproductive entrepreneurship scores.

Given the effects reported in Tables 4.3 and 4.4, the negative estimated effect of total adherents on net entrepreneurship that is reported in Table 4.5 is not surprising. Recall that a state's net entrepreneurship score is its productive entrepreneurship score minus its unproductive entrepreneurship score. The percent of a state's population that report themselves as Christian is negatively and significantly associated with productive entrepreneurship in a state; positively and significantly associated with unproductive entrepreneurship. So it would stand to reason that it 
enters significantly into a regression with the net score as the dependent variable. What may be surprising in Table 4.5, however, is the fact that the estimated effect of atheist/agnostic is positive and significant. This variable did not enter significantly in the unproductive entrepreneurship regression reported in Table 4.4, but its estimated (positive) association with productive entrepreneurship is enough to produce the statistically significant estimated effect on net entrepreneurship.

One could argue that, taken individually, significant results reported in Table 4.3 through Table 4.5 are driven by collinearity with the omitted religion variables in each regression. Table 4.6 provides a correlation matrix for the belief and belonging variables. In Table 4.7 we provide regression results for each of our dependent variables that include all religion variables that exhibit statistical significance in any of the Table 4.3 through Table 4.5 results. Even only that subset of religion variables together is pushing the degrees of freedom available with the U.S. state-level data. Also, introducing such collinear variables is likely to inflate standard errors. However, it is the next logical step as a robustness check and we are interested to see whether or not any of the statistically significant religion variable effects hold up.

In each specification reported in Table 4.7, the effect of total adherents is statistically significant and of the same sign as reported in previous tables. A sample standard deviation increase in total adherents is associated with an approximate 3 point decrease in a state's productive entrepreneurship score (significant at the five percent level or better); a 5 point increase in a state's unproductive entrepreneurship score (significant at the ten percent level or above); and an 8 point decrease in a state's net entrepreneurship score (significant at the five percent level or better). However, none of the other religion variables, including atheist/agnostic, enter significantly into any of the regressions reported in Table 4.7. 
Again, due to collinearity and relatively few degrees of freedom, we do not interpret this as a reason to dismiss the previous significant results, in particular those associated with productive entrepreneurship (Table 4.3). Rather, what we take from Table 4.7 is particular confidence that general religious belonging, as proxied for by total adherents, is negatively related to productive entrepreneurship; positively related to unproductive entrepreneurship. However, as a check on whether other significant results from Table $\mathbf{4 . 3}$ (for productive entrepreneurship) should be dismissed as artifacts of total adherents' omission, Table 4.8 reports productive entrepreneurship regressions that include, separately, attendance, prayer, importance, and atheist/agnostic; while total adherents is included (along with the other baseline controls) in all regressions. As it turns out, with one exception all religious variables are rendered insignificant when total adherents is included. The exception is atheist/agnostic (column 4 of Table 4.8) whose estimated effect is positive and significant at the five percent level. However, the point estimate is less than half the size of that reported in Table 4.3. A sample standard deviation increase (3.26) in the percent of individuals reporting themselves as atheist or agnostic is associated with about a 1.6 point increase in a state's productive entrepreneurship score.

\subsection{Conclusion}

In this paper we have explored the relationships between measures of religiosity and the levels of entrepreneurial activity, both productive and unproductive, using cross-section U.S. state level data. To our knowledge, this is the only applied analysis of religion and entrepreneurship to incorporate Baumol's (1990) conjectures on the role of institutions in determining whether entrepreneurs will channel their efforts towards wealth-generating activities or towards zero- or negative-sum rent-seeking. We also utilize various measures of both the belief (e.g., the 
frequency of prayer) and belonging (e.g., protestant affiliation) dimensions of religiosity. This distinction in religious institutions, both formal and informal, has been stressed by authors such as Barro and McCleary (2003).

We find that measures of both religious belief and belonging tend to correlate negatively and significantly with a state's productive entrepreneurship score. However, only a measure most straightforwardly interpreted as belonging (the percent of state's population that reports themselves as Christian adherents) is robustly correlated with productive entrepreneurship. This could be because religion imposes opportunity costs in terms of time and resources that may otherwise have been devoted towards productive entrepreneurship. For example, time spent in church reduces time available for engaging in business activity. More subjectively, religion may create psychic costs to pursuing worldly gains rather than salvation in the beyond.

However, the same measure of total Christian adherents is robustly and positively correlated with states' unproductive entrepreneurship scores. This suggests something beyond a simple opportunity cost story. Alternatively, religion may correlate negatively with productive entrepreneurship because its institutions increase the relative net benefits of rent-seeking. Presumably religious obligations would consume time and resources that could be used for either wealth-generating or rent-seeking activities. Also, the percent of a state's population that reports themselves as atheist and/or agnostic is positively and significantly related to productive entrepreneurship (even when controlling for total Christian adherents) but has no significant relationship with unproductive entrepreneurship.

One possibility is that productive entrepreneurial activities are largely substitutes for religious ones while unproductive entrepreneurial activities are complementary. Independent of the depth of adherent's beliefs, churches or other religious forums may function as special 
interest groups. The most well-known example of this is the Christian Coalition of America. We do not wish to claim that this special interest group is especially prone to rent-seeking. However, there may be religious groups generally that, like the Christian Coalition, function as special interests and do indeed work through political processes to capture rents for their members. The time and resources used in these religious activities would not be available for wealth-generating ones, leading to substitution away from productive entrepreneurial activities. 
FIGURE 4.1 - RELATIONSHIPS BETWEEN ENTREPRENEURSHIP SCORES AND WORSHIP SERVICE ATTENDANCE
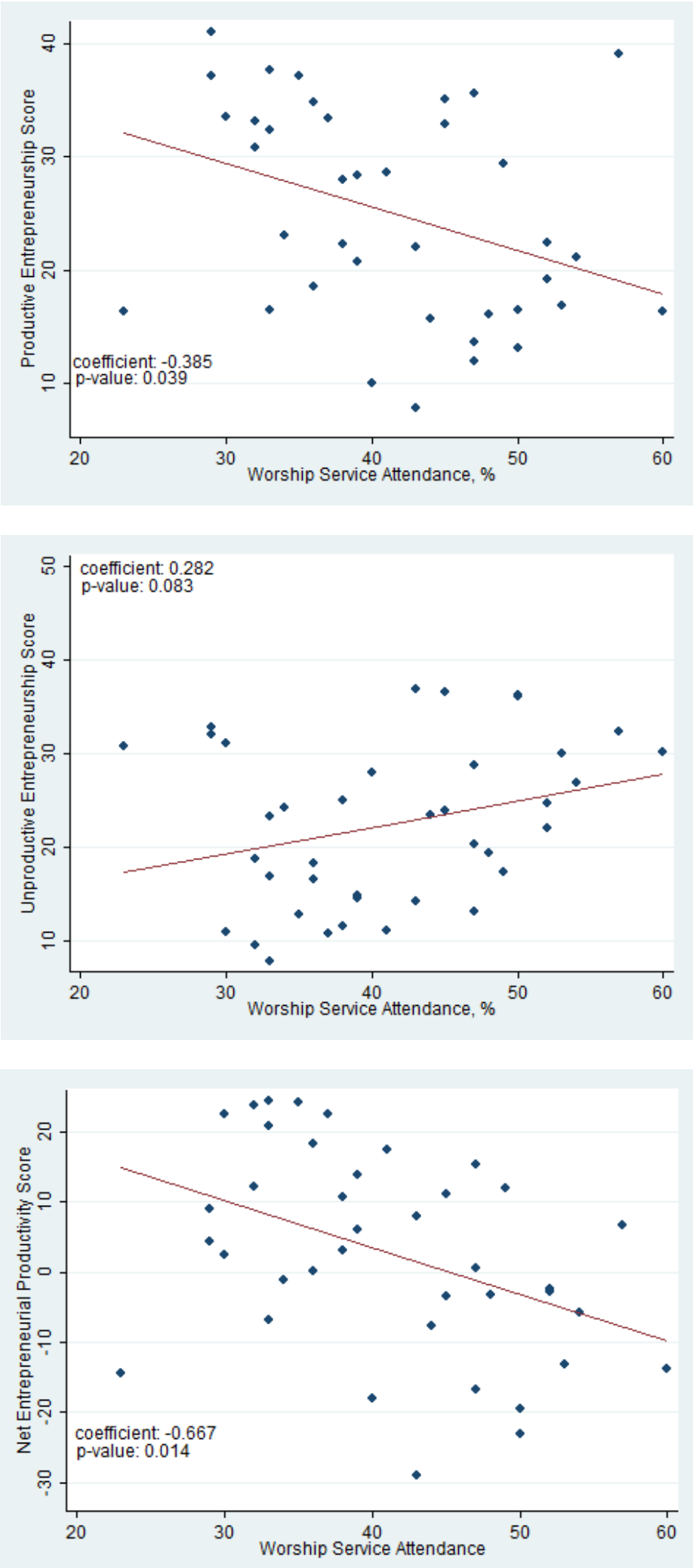
FIGURE 4.2 - RELATIONSHIPS BETWEEN ENTREPRENEURSHIP SCORES AND BELIEF IN GOD
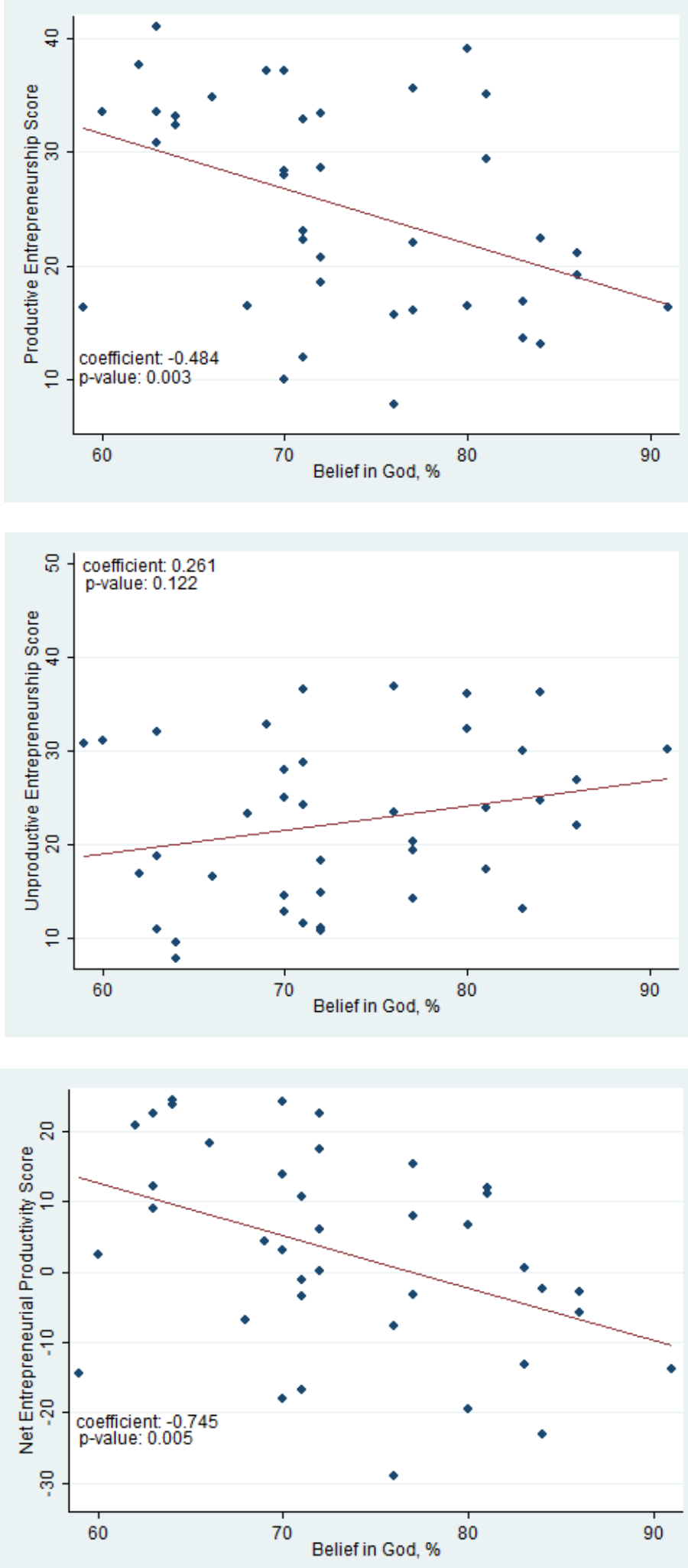
Figure 4.3 - Relationships BetWeEn ENTREPRENEURSHIP SCORES AND FREQUENCY OF PRAYER
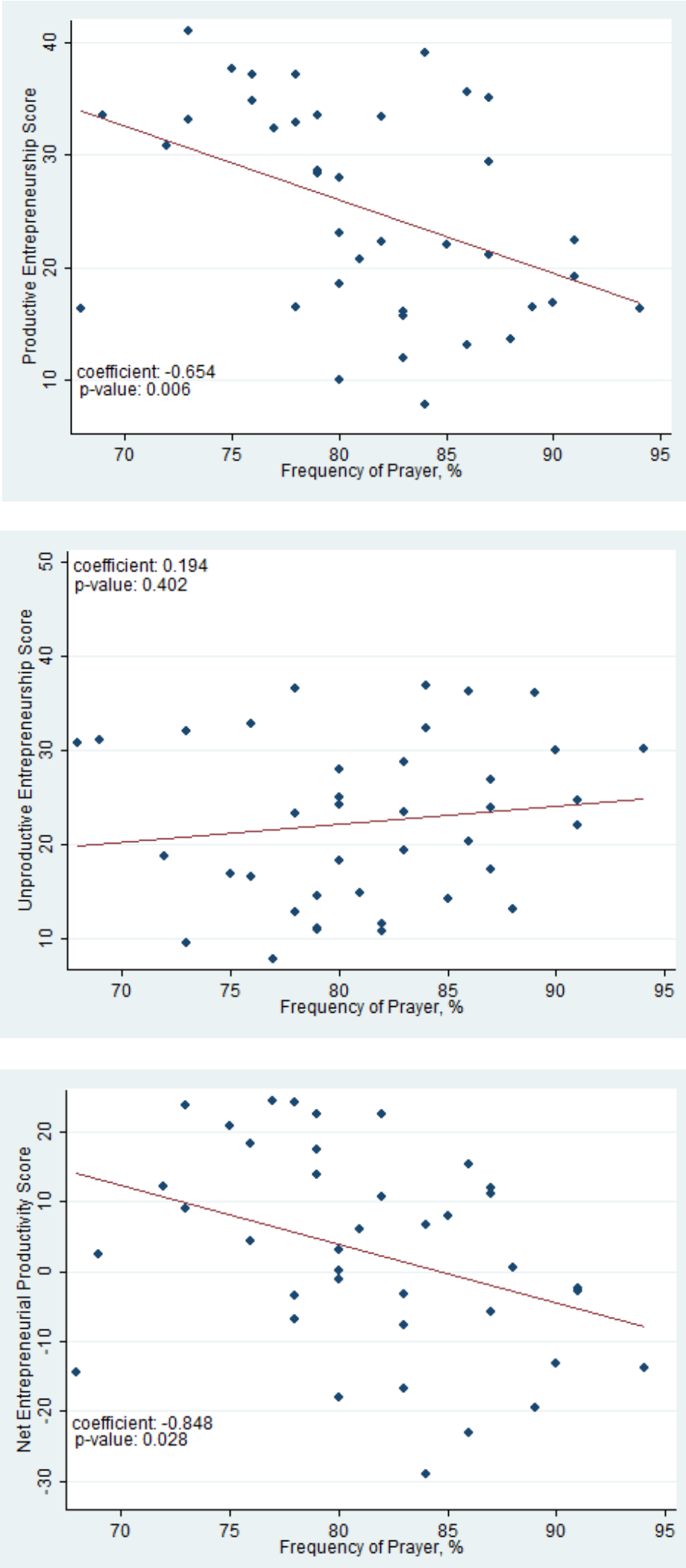
FIGURE 4.4 - RELATIONSHIPS BETWEEN ENTREPRENEURSHIP SCORES AND IMPORTANCE OF RELIGION
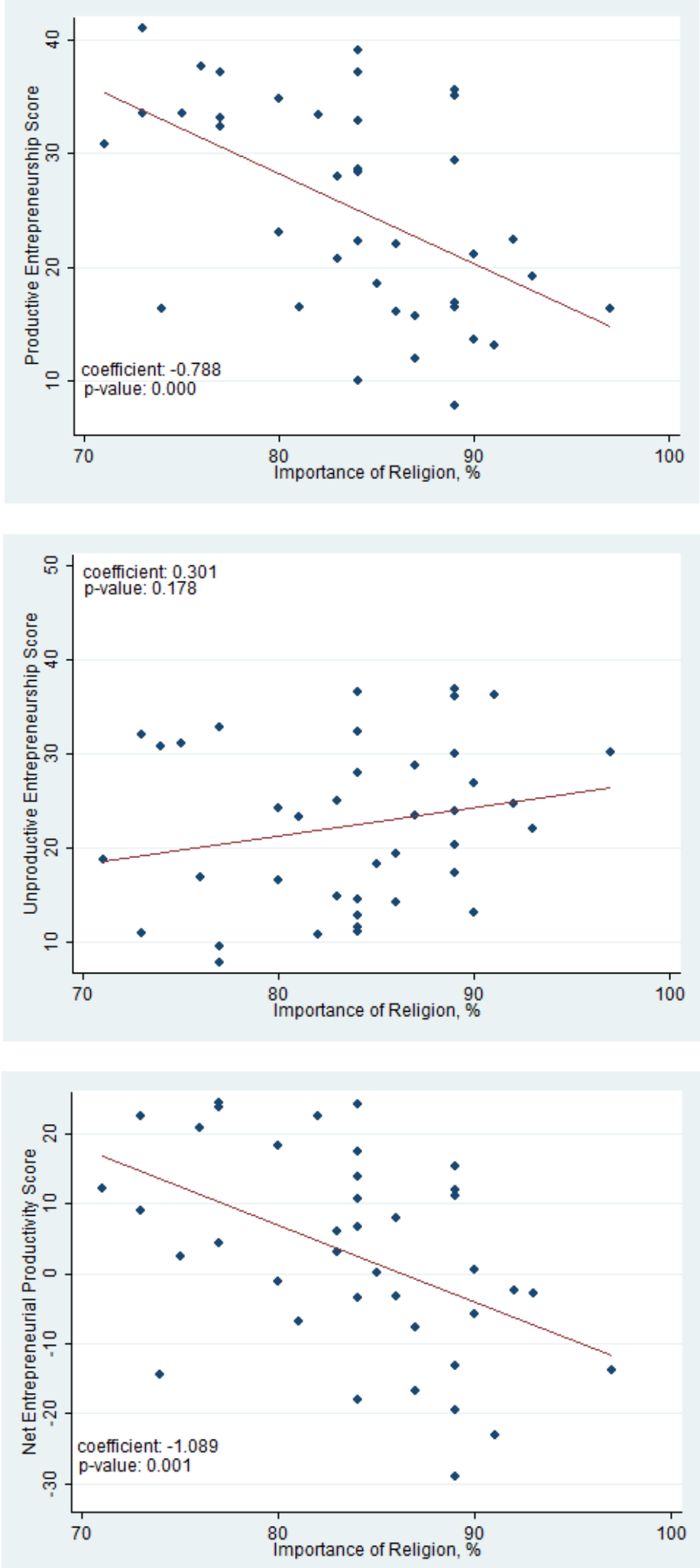
TABLE 4.1 - DATA DESCRIPTION AND SOURCES FOR VARIABLES USED IN THE CONSTRUCTION OF ENTREPRENEURSHIP SCORES

\begin{tabular}{ll}
\hline \hline Variable & Description \\
\hline \multicolumn{2}{l}{ Measures used to construct Productive Entrepreneurship scores } \\
\hline $\begin{array}{l}\text { Venture Capital } \\
\text { Investment Per Capita }\end{array}$ & $\begin{array}{l}\text { Average annual venture capital investment (all sources, including non-U.S.) per capita } \\
(2001-2008)\end{array}$ \\
$\begin{array}{ll}\text { Patents Per Capita }{ }^{2} \\
\begin{array}{l}\text { Sole Proprietorship } \\
\text { Growth Rate }\end{array}\end{array}$ & $\begin{array}{l}\text { Average annual number of utility patents granted (2001-2008) per 100,000 population } \\
\text { force (NPE), calculated as [(NPE2008 - NPE2001)/NPE2000]*100 }\end{array}$ \\
$\begin{array}{l}\text { Total Establishment } \\
\text { Birth Rate }\end{array}$ & $\begin{array}{l}100 * \text { Average annual number of new establishment births as a percent of existing firms } \\
(2001-2008)\end{array}$ \\
$\begin{array}{l}\text { Large Firm } \\
\text { Establishment Birth } \\
\text { Rate }^{3}\end{array}$ & $\begin{array}{l}100 * \text { Average annual number of new 500+ employee establishment births as a percent of } \\
\text { existing large firms (2001-2008) }\end{array}$ \\
\hline Measures used to construct Unproductive Entrepreneurship scores \\
\hline
\end{tabular}

Lobby Measure $1^{4} \quad$ Number of Establishments in NAICS code 813940 (Political Organizations) in state capitals per 1,000,000 population (2001-2008)

Lobby Measure $2^{4} \quad$ Number of Establishments in NAICS code 813940, 813410, 813312, 561599, 813910, 813990 (Political Organizations, and Membership Organizations) in state capitals per 1,000,000 population (2001-2008)

Lobby Measure $3^{4} \quad$ Number of Establishments in NAICS code 813940, 813410, 813312, 561599, 813910, 813990, 813212, 813219, 813311, 813312, 813319 (Political Organizations, Membership Organizations, and Social Service Organizations) in state capitals per 1,000,000 population (2001-2008)

Unproductive Legal 100 minus the Harris Poll score. The Harris Poll score measures the quality of each state's Entrepreneurship $^{5} \quad$ liability system on a 100 point scale. By our conversion, a score of 100 now represents a "poor quality" judicial system. (2001-2008)

Notes: Productive, unproductive, and net entrepreneurial activity scores for our analysis were constructed by first calculating the measures according to Sobel (2008) methods for the period 2001-2008. We then averaged our scores with Sobel's (2008) scores. SIC codes used in Sobel (2008) for the construction of lobby measures have since been updated to the NAICS system. The NAICS codes used here have been mapped to the SIC codes used by Sobel with an index provided at www.naics.com.

\section{Sources}

1. U.S. Department of Commerce, Bureau of Economic Analysis, State and Local Area Data

2. U.S. Patent and Trademark Office, Utility Patent Counts by Country/State and Year

3. Office of Advocacy, U.S. Small Business Administration, U.S. Census Bureau, Statistics of U.S. Business.

4. Sobel (2008) and County Business Patterns, U.S. Census Bureau.

5. Institute for Legal Reform and U.S. Chamber of Commerce, State Liability System Ranking. 
TABLE 4.2 - SUMMARY STATISTICS

\begin{tabular}{|c|c|c|c|c|c|c|}
\hline Variable & Data Source & Obs & Mean & $\begin{array}{l}\text { Std. } \\
\text { Dev. }\end{array}$ & Min. & Max. \\
\hline Net Entrepreneurial Productivity Score & $\begin{array}{l}\text { Sobel (2008) and } \\
\text { authors' own estimates }\end{array}$ & 48 & 0.38 & 15.01 & -32.52 & 24.48 \\
\hline Productive Entrepreneurship Score & $\begin{array}{l}\text { Sobel (2008) and } \\
\text { authors' own estimates }\end{array}$ & 48 & 24.38 & 9.34 & 6.21 & 41.06 \\
\hline Unproductive Entrepreneurship Score & $\begin{array}{l}\text { Sobel (2008) and } \\
\text { authors' own estimates }\end{array}$ & 48 & 24.00 & 9.35 & 7.88 & 43.59 \\
\hline Attendance, $\%$ & Pew Forum & 39 & 41.10 & 8.87 & 23.00 & 60.00 \\
\hline Belief in God, \% & Pew Forum & 39 & 73.21 & 8.09 & 59.00 & 91.00 \\
\hline Prayer, $\%$ & Pew Forum & 39 & 16.74 & 2.39 & 11.00 & 21.00 \\
\hline Importance, $\%$ & Pew Forum & 39 & 83.80 & 6.20 & 71.00 & 97.00 \\
\hline Christian Adherents, $\%$ & Census Bureau & 48 & 48.85 & 10.18 & 30.65 & 76.70 \\
\hline Protestant, \% & Gallup Poll & 48 & 52.07 & 14.25 & 12.30 & 75.80 \\
\hline Catholic, \% & Gallup Poll & 48 & 23.42 & 11.55 & 6.40 & 51.50 \\
\hline Atheist/Agnostic, \% & Gallup Poll & 48 & 9.05 & 3.26 & 3.50 & 17.90 \\
\hline Log GDP Per Capita & $\begin{array}{l}\text { U.S. Department of } \\
\text { Commerce, BEA }\end{array}$ & 48 & 10.56 & 0.17 & 10.22 & 11.03 \\
\hline EFNA & Fraser Institute & 48 & 6.94 & 0.53 & 5.44 & 8.32 \\
\hline Pop. Density & Census Bureau & 48 & 189.43 & 258.15 & 5.27 & 1156.99 \\
\hline Median Age & Census Bureau & 48 & 36.09 & 1.97 & 27.58 & 39.64 \\
\hline Bachelor's,$+ \%$ & Census Bureau & 48 & 24.99 & 4.53 & 15.67 & 35.09 \\
\hline Male Pop., \% & Census Bureau & 48 & 49.18 & 0.66 & 48.20 & 50.92 \\
\hline
\end{tabular}


TABLe 4.3 - Regressions of Productive ENTREPRENEURShip SCORES

\begin{tabular}{|c|c|c|c|c|c|c|c|c|}
\hline \multicolumn{9}{|c|}{ Specifications } \\
\hline Independent variable & 1 & 2 & 3 & 4 & 5 & 6 & 7 & 8 \\
\hline \multicolumn{9}{|l|}{ Religiosity } \\
\hline Attendance, $\%$ & $\begin{array}{c}-0.437^{* *} \\
(2.30)\end{array}$ & - & - & - & - & - & - & - \\
\hline Belief in God, \% & - & $\begin{array}{c}-0.233 \\
(0.94)\end{array}$ & - & - & - & - & - & - \\
\hline Prayer, \% & - & - & $\begin{array}{c}-0.940^{* *} \\
(2.03)\end{array}$ & - & - & - & - & - \\
\hline Importance, $\%$ & - & - & - & $\begin{array}{c}-0.639^{* *} \\
(2.36)\end{array}$ & - & - & - & - \\
\hline \multicolumn{9}{|l|}{ Affiliation } \\
\hline Total Adherents, $\%$ & - & - & - & - & $\begin{array}{c}-0.467^{* * * *} \\
(6.46)\end{array}$ & - & - & - \\
\hline Protestant, $\%$ & - & - & - & - & - & $\begin{array}{l}-0.127 \\
(1.46)\end{array}$ & - & - \\
\hline Catholic, \% & - & - & - & - & - & - & $\begin{array}{l}-0.150 \\
(1.59)\end{array}$ & - \\
\hline Atheist/Agnostic, \% & - & - & - & - & - & - & - & $\begin{array}{c}1.213^{* * * *} \\
(5.0 .)\end{array}$ \\
\hline \multicolumn{9}{|l|}{ Controls } \\
\hline \multirow[t]{2}{*}{ Log GDP Per Capita } & -11.331 & -7.957 & -3.515 & -10.921 & -7.480 & -12.541 & -9.461 & -9.692 \\
\hline & $(0.82)$ & $(0.51)$ & $(0.25)$ & $(2.36)$ & $(0.88)$ & $(1.16)$ & $(0.79)$ & $(1.06)$ \\
\hline \multirow[t]{2}{*}{ EFNA } & $5.760^{*}$ & 5.196 & 4.158 & $6.355^{* *}$ & $4.946^{* *}$ & $7.337^{* *}$ & $6.486^{* *}$ & $6.190^{* *}$ \\
\hline & $(1.86)$ & $(1.44)$ & $(1.52)$ & $(1.96)$ & $(2.35)$ & $(2.51)$ & $(2.11)$ & $(2.48)$ \\
\hline \multirow[t]{2}{*}{ Pop. Density } & $0.013^{* * *}$ & $0.013^{* *}$ & $0.013^{*}$ & $0.013^{* *}$ & $0.016^{* * * *}$ & $0.010^{*}$ & $0.017^{* * * *}$ & $0.013^{* * *}$ \\
\hline & $(2.67)$ & $(2.21)$ & (1.94) & $(2.58)$ & (3.88) & $(1.94)$ & (2.86) & $(3.25)$ \\
\hline \multirow{2}{*}{ Median Age } & $-2.187^{* *}$ & $-1.409^{*}$ & -0.315 & $-1.725^{* *}$ & $-2.807^{* * *}$ & $-1.025^{*}$ & $-1.002^{*}$ & $-1.872^{* * *}$ \\
\hline & $(2.63)$ & $(1.94)$ & $(0.50)$ & $(2.43)$ & $(5.53)$ & $(1.78)$ & $(1.76)$ & (3.54) \\
\hline \multirow[t]{2}{*}{ Bachelor's,$+ \%$} & $0.544^{*}$ & $0.642^{*}$ & $1.041^{* * *}$ & 0.442 & $0.714^{* * *}$ & $0.785^{* * *}$ & $1.012^{* * *}$ & $0.615^{* * * *}$ \\
\hline & $(1.75)$ & $(1.80)$ & $(2.73)$ & $(1.31)$ & (3.60) & (2.99) & $(4.09)$ & $(2.92)$ \\
\hline \multirow[t]{2}{*}{ Male Pop., \% } & 1.229 & 2.926 & $5.313^{* * *}$ & 0.590 & 0.543 & -1.494 & 3.130 & -0.583 \\
\hline & $(0.56)$ & (1.16) & $(3.46)$ & $(0.24)$ & $(0.40)$ & $(0.72)$ & $(1.47)$ & $(0.31)$ \\
\hline$R^{2}$ & 0.707 & 0.666 & 0.694 & 0.705 & 0.784 & 0.627 & 0.624 & 0.727 \\
\hline Observations & 39 & 39 & 39 & 39 & 48 & 48 & 48 & 48 \\
\hline
\end{tabular}

Notes: Absolute values of t-statistics are in parentheses. *,**, and *** denotes significance at the 10 percent, 5 percent, and 1 percent levels, respectively. Constant included, but not reported. 
TABLE 4.4 - REGRESSIONS OF UNPRODUCTIVE ENTREPRENEURSHIP SCORES

\begin{tabular}{|c|c|c|c|c|c|c|c|c|}
\hline \multicolumn{9}{|c|}{ Specifications } \\
\hline Independent variable & 1 & 2 & 3 & 4 & 5 & 6 & 7 & 8 \\
\hline \multicolumn{9}{|l|}{ Religiosity } \\
\hline Attendance, $\%$ & $\begin{array}{l}0.023 \\
(0.09)\end{array}$ & - & - & - & - & - & - & - \\
\hline Belief in God, \% & - & $\begin{array}{l}0.343 \\
(0.87)\end{array}$ & - & - & - & - & - & - \\
\hline Prayer, $\%$ & - & - & $\begin{array}{l}0.254 \\
(0.32)\end{array}$ & - & - & - & - & - \\
\hline Importance, $\%$ & - & - & - & $\begin{array}{r}-0.047 \\
(0.11)\end{array}$ & - & - & - & - \\
\hline \multicolumn{9}{|l|}{ Affiliation } \\
\hline Total Adherents, $\%$ & - & - & - & - & $\begin{array}{c}0.381^{\text {*** }} \\
(2.80)\end{array}$ & - & - & - \\
\hline Protestant, $\%$ & - & - & - & - & - & $\begin{array}{r}-0.031 \\
(0.24)\end{array}$ & - & - \\
\hline Catholic, \% & - & - & - & - & - & - & $\begin{array}{l}0.200 \\
(1.14)\end{array}$ & - \\
\hline Atheist/Agnostic, \% & - & - & - & - & - & - & - & $\begin{array}{c}-0.552 \\
(1.20)\end{array}$ \\
\hline \multicolumn{9}{|l|}{ Controls } \\
\hline Log GDP Per Capita & $\begin{array}{c}-33.091 \\
(1.62)\end{array}$ & $\begin{array}{c}-43.942^{*} \\
(1.86)\end{array}$ & $\begin{array}{c}-32.947^{*} \\
(1.87)\end{array}$ & $\begin{array}{c}-34.368^{*} \\
(1.68)\end{array}$ & $\begin{array}{c}-27.822^{*} \\
(1.92)\end{array}$ & $\begin{array}{c}-24.058 \\
(1.53)\end{array}$ & $\begin{array}{c}-27.624^{*} \\
(1.73)\end{array}$ & $\begin{array}{c}-25.110^{*} \\
(1.68)\end{array}$ \\
\hline EFNA & $\begin{array}{l}0.565 \\
(0.12)\end{array}$ & $\begin{array}{l}3.065 \\
(0.53)\end{array}$ & $\begin{array}{l}0.523 \\
(0.13)\end{array}$ & $\begin{array}{c}0.884 \\
(0.17)\end{array}$ & $\begin{array}{r}-2.071 \\
(0.60)\end{array}$ & $\begin{array}{r}-3.535 \\
(0.87)\end{array}$ & $\begin{array}{c}-3.126 \\
(0.79)\end{array}$ & $\begin{array}{c}-3.335 \\
(0.93)\end{array}$ \\
\hline Pop. Density & $\begin{array}{r}-0.001 \\
(0.07)\end{array}$ & $\begin{array}{l}-0.001 \\
(0.05)\end{array}$ & $\begin{array}{l}0.001 \\
(0.11)\end{array}$ & $\begin{array}{l}0.001 \\
(0.05)\end{array}$ & $\begin{array}{l}0.007 \\
(070)\end{array}$ & $\begin{array}{l}0.008 \\
(071)\end{array}$ & $\begin{array}{l}0.005 \\
(0.48)\end{array}$ & 0.009 \\
\hline Median Age & $\begin{array}{c}-0.756 \\
(0.76)\end{array}$ & $\begin{array}{l}-1.422 \\
(1.38)\end{array}$ & $\begin{array}{c}-1.003 \\
(1.11)\end{array}$ & $\begin{array}{c}-0.871 \\
(1.01)\end{array}$ & $\begin{array}{l}(.034 \\
(1.24)\end{array}$ & $\begin{array}{c}-0.225 \\
(0.29)\end{array}$ & $\begin{array}{l}(0.70) \\
-0.548 \\
(0.68)\end{array}$ & $\begin{array}{l}0.031 \\
(0.04)\end{array}$ \\
\hline Bachelor's,$+ \%$ & $\begin{array}{l}0.434 \\
(0.71)\end{array}$ & $\begin{array}{l}0.264 \\
(0.45)\end{array}$ & $\begin{array}{l}0.333 \\
(0.53)\end{array}$ & $\begin{array}{l}0.391 \\
(0.64)\end{array}$ & $\begin{array}{l}0.443 \\
(1.15)\end{array}$ & $\begin{array}{l}0.234 \\
(0.50)\end{array}$ & $\begin{array}{l}0.154 \\
(0.35)\end{array}$ & $\begin{array}{l}0.410 \\
(0.99)\end{array}$ \\
\hline Male Pop., \% & $\begin{array}{l}0.133 \\
(0.04)\end{array}$ & $\begin{array}{l}-2.936 \\
(0.62) \\
\end{array}$ & $\begin{array}{l}-0.175 \\
(0.06)\end{array}$ & $\begin{array}{l}-0.373 \\
(0.09)\end{array}$ & $\begin{array}{l}5.493^{*} \\
(1.93)\end{array}$ & $\begin{array}{l}3.418 \\
(0.96)\end{array}$ & $\begin{array}{l}3.167 \\
(0.98) \\
\end{array}$ & $\begin{array}{l}5.216 \\
(1.51) \\
\end{array}$ \\
\hline$\overline{R^{2}}$ & 0.282 & 0.299 & 0.285 & 0.282 & 0.335 & 0.222 & 0.244 & 0.244 \\
\hline Observations & 39 & 39 & 39 & 39 & 48 & 48 & 48 & 48 \\
\hline
\end{tabular}

Notes: Absolute values of t-statistics are in parentheses. *,**, and *** denotes significance at the 10 percent, 5 percent, and 1 percent levels, respectively. Constant included, but not reported. 
Table 4.5 - Regressions of Net Entrepreneurial Produtivity Scores

\begin{tabular}{|c|c|c|c|c|c|c|c|c|}
\hline \multicolumn{9}{|c|}{ Specifications } \\
\hline Independent variable & 1 & 2 & 3 & 4 & 5 & 6 & 7 & 8 \\
\hline \multicolumn{9}{|l|}{ Religiosity } \\
\hline Attendance, $\%$ & $\begin{array}{c}-0.460 \\
(1.37)\end{array}$ & - & - & - & - & - & - & - \\
\hline Belief in God, \% & - & $\begin{array}{l}-0.110 \\
(0.458)\end{array}$ & - & - & - & - & - & - \\
\hline Prayer, \% & - & - & $\begin{array}{c}-1.194 \\
(1.11)\end{array}$ & - & - & - & - & - \\
\hline Importance, $\%$ & - & - & - & $\begin{array}{c}-0.592 \\
(1.08)\end{array}$ & - & - & - & - \\
\hline \multicolumn{9}{|l|}{ Affiliation } \\
\hline Total Adherents, $\%$ & - & - & - & - & $\begin{array}{c}-0.848^{* * *} \\
(5.69)\end{array}$ & - & - & - \\
\hline Protestant, \% & - & - & - & - & - & $\begin{array}{c}-0.096 \\
(0.52)\end{array}$ & - & - \\
\hline Catholic, $\%$ & - & - & - & - & - & - & $\begin{array}{c}-0.350 \\
(1.55)\end{array}$ & - \\
\hline Atheist/Agnostic, \% & - & - & - & - & - & - & - & $\begin{array}{c}1.765^{* * *} \\
(3.07)\end{array}$ \\
\hline \multicolumn{9}{|l|}{ Controls } \\
\hline Log GDP Per Capita & $\begin{array}{c}21.760 \\
(0.74)\end{array}$ & $\begin{array}{c}35.985 \\
(1.13)\end{array}$ & $\begin{array}{c}29.432 \\
(1.11)\end{array}$ & $\begin{array}{c}23.446 \\
(0.80)\end{array}$ & $\begin{array}{c}20.342 \\
(1.02)\end{array}$ & $\begin{array}{c}11.517 \\
(0.48)\end{array}$ & $\begin{array}{c}18.163 \\
(0.74)\end{array}$ & $\begin{array}{c}15.419 \\
(0.72)\end{array}$ \\
\hline EFNA & $\begin{array}{l}5.195 \\
(0.80)\end{array}$ & $\begin{array}{l}2.131 \\
(0.28)\end{array}$ & $\begin{array}{l}3.635 \\
(0.61)\end{array}$ & $\begin{array}{l}5.471 \\
(0.81)\end{array}$ & $\begin{array}{l}7.017 \\
(1.44)\end{array}$ & $\begin{array}{c}10.872^{*} \\
(1.70)\end{array}$ & $\begin{array}{l}9.612 \\
(1.50)\end{array}$ & $\begin{array}{l}9.525^{*} \\
(1.76)\end{array}$ \\
\hline Pop. Density & $\begin{array}{l}0.013 \\
(1.25)\end{array}$ & $\begin{array}{l}0.014 \\
(1.25)\end{array}$ & $\begin{array}{l}0.012 \\
(1.13)\end{array}$ & $\begin{array}{l}0.013 \\
(1.24)\end{array}$ & $\begin{array}{l}0.009 \\
(0.81)\end{array}$ & $\begin{array}{l}0.002 \\
(0.14)\end{array}$ & $\begin{array}{l}0.012 \\
(0.97)\end{array}$ & $\begin{array}{l}0.005 \\
(0.35)\end{array}$ \\
\hline Median Age & $\begin{array}{c}-1.431 \\
(0.92)\end{array}$ & $\begin{array}{l}0.013 \\
(0.01)\end{array}$ & $\begin{array}{l}0.688 \\
(0.51)\end{array}$ & $\begin{array}{r}-0.851 \\
(0.62)\end{array}$ & $\begin{array}{c}-3.840^{\text {**** }} \\
(3.40)\end{array}$ & $\begin{array}{c}-0.800 \\
(0.64)\end{array}$ & $\begin{array}{c}-0.455 \\
(0.36)\end{array}$ & $\begin{array}{r}-1.903 \\
(1.55)\end{array}$ \\
\hline Bachelor's,$+ \%$ & $\begin{array}{l}0.121 \\
(0.17)\end{array}$ & $\begin{array}{l}0.378 \\
(0.54)\end{array}$ & $\begin{array}{l}0.709 \\
(1.00)\end{array}$ & $\begin{array}{l}0.051 \\
(0.07)\end{array}$ & $\begin{array}{l}0.271 \\
(0.62)\end{array}$ & $\begin{array}{l}0.551 \\
(0.93)\end{array}$ & $\begin{array}{l}0.858 \\
(1.52)\end{array}$ & $\begin{array}{l}0.205 \\
(0.41)\end{array}$ \\
\hline Male Pop., \% & $\begin{array}{r}1.096 \\
(0.24) \\
\end{array}$ & $\begin{array}{l}5.862 \\
(1.00)\end{array}$ & $\begin{array}{l}5.488 \\
(1.56)\end{array}$ & $\begin{array}{c}-0.963 \\
(0.18)\end{array}$ & $\begin{array}{c}-4.950 \\
(1.44)\end{array}$ & $\begin{array}{c}-1.924 \\
(0.39)\end{array}$ & $\begin{array}{r}-0.037 \\
(0.01)\end{array}$ & $\begin{array}{r}-5.798 \\
(1.23) \\
\end{array}$ \\
\hline$R^{2}$ & 0.516 & 0.494 & 0.517 & 0.510 & 0.622 & 0.405 & 0.429 & 0.496 \\
\hline Observations & 39 & 39 & 39 & 39 & 48 & 48 & 48 & 48 \\
\hline
\end{tabular}

Notes: Absolute values of t-statistics are in parentheses. *,**, and *** denotes significance at the 10 percent, 5 percent, and 1 percent levels, respectively. Constant included, but not reported. 
TABLE 4.6-CORRELATION MATRIX OF RELIGION VARIABLES

\begin{tabular}{|c|c|c|c|c|c|}
\hline \multirow[b]{3}{*}{$\begin{array}{c}\text { Independent } \\
\text { Variables }\end{array}$} & \multicolumn{5}{|c|}{ Variables that exhibit statistical significance in Tables 4.3-4.5 } \\
\hline & Attendance, $\%$ & Prayer, \% & Importance, $\%$ & Total Adherents, $\%$ & Atheist/Agnostic, $\%$ \\
\hline & & & & & \\
\hline Attendance, $\%$ & 1.00 & -0.47 & 0.90 & 0.61 & -0.70 \\
\hline Belief in God, \% & 0.93 & -0.49 & 0.93 & 0.48 & -0.75 \\
\hline Prayer, $\%$ & -0.47 & 1.00 & -0.48 & -0.04 & 0.19 \\
\hline Importance, $\%$ & 0.90 & -0.48 & 1.00 & 0.52 & -0.68 \\
\hline Total Adherents, \% & 0.61 & -0.04 & 0.52 & 1.00 & -0.63 \\
\hline Protestant, \% & 0.51 & -0.14 & 0.57 & -0.05 & -0.50 \\
\hline Catholic, $\%$ & 0.67 & 0.42 & -0.62 & -0.04 & 0.22 \\
\hline Atheist/Agnostic, $\%$ & 0.70 & 0.19 & -0.68 & -0.63 & 1.00 \\
\hline
\end{tabular}

Notes: Correlations are reported in absolute value. 
TAble 4.7 - Regressions of Net, Productive, AND UNPRODUCTIVE ENTREPRENEURSHIP SCORES INCLUDING All Previously Significant Religion Variables

\begin{tabular}{|c|c|c|c|}
\hline \multirow[b]{2}{*}{ Independent variable } & \multicolumn{3}{|c|}{ Dependent Variable } \\
\hline & $\begin{array}{c}\text { Net Entrepreneurial } \\
\text { Productivity }\end{array}$ & $\begin{array}{c}\text { Productive } \\
\text { Entrepreneurship }\end{array}$ & $\begin{array}{l}\text { Unproductive } \\
\text { Entrepreneurship }\end{array}$ \\
\hline \multicolumn{4}{|l|}{ Religiosity } \\
\hline Attendance, $\%$ & $\begin{array}{l}0.018 \\
(0.04)\end{array}$ & $\begin{array}{l}-0.147 \\
(0.64)\end{array}$ & $\begin{array}{l}-0.165 \\
(0.46)\end{array}$ \\
\hline Prayer, \% & $\begin{array}{l}0.385 \\
(0.36)\end{array}$ & $\begin{array}{l}-0.265 \\
(0.54)\end{array}$ & $\begin{array}{l}-0.651 \\
(0.69)\end{array}$ \\
\hline Importance, $\%$ & $\begin{array}{l}-0.305 \\
(0.40) \\
\end{array}$ & $\begin{array}{l}-0.209 \\
(0.56) \\
\end{array}$ & $\begin{array}{l}0.100 \\
(0.16) \\
\end{array}$ \\
\hline \multicolumn{4}{|l|}{ Affiliation } \\
\hline Total Adherents, $\%$ & $\begin{array}{c}-0.858^{* *} \\
(2.52)\end{array}$ & $\begin{array}{c}-0.345^{* *} \\
(2.05)\end{array}$ & $\begin{array}{l}0.514^{*} \\
(1.78)\end{array}$ \\
\hline Atheist/Agnostic, \% & $\begin{array}{l}-0.565 \\
(0.70) \\
\end{array}$ & $\begin{array}{l}0.005 \\
(0.01) \\
\end{array}$ & $\begin{array}{l}0.570 \\
(0.76) \\
\end{array}$ \\
\hline \multicolumn{4}{|l|}{ Controls } \\
\hline Log GDP Per Capita & $\begin{array}{l}22.387 \\
(0.75)\end{array}$ & $\begin{array}{c}-12.275 \\
(0.97)\end{array}$ & $\begin{array}{c}-34.662 \\
(1.55)\end{array}$ \\
\hline EFNA & $\begin{array}{l}3.323 \\
(0.45)\end{array}$ & $\begin{array}{l}5.505^{* *} \\
(2.05)\end{array}$ & $\begin{array}{l}2.181 \\
(0.35)\end{array}$ \\
\hline Pop. Density & $\begin{array}{l}0.017^{*} \\
(1.72)\end{array}$ & $\begin{array}{l}0.015^{* *} \\
(2.63)\end{array}$ & $\begin{array}{l}-0.002 \\
(0.36)\end{array}$ \\
\hline Median Age & $\begin{array}{l}-3.617^{*} \\
(1.97)\end{array}$ & $\begin{array}{l}-2.743^{* * *} \\
(2.64)\end{array}$ & $\begin{array}{l}0.874 \\
(0.64)\end{array}$ \\
\hline Bachelor's,$+ \%$ & $\begin{array}{l}0.287 \\
(0.39)\end{array}$ & $\begin{array}{l}0.710^{*} \\
(1.95)\end{array}$ & $\begin{array}{l}0.423 \\
(0.64)\end{array}$ \\
\hline Male Pop., \% & $\begin{array}{r}-2.514 \\
(0.48) \\
\end{array}$ & $\begin{array}{r}-0.704 \\
(0.28) \\
\end{array}$ & $\begin{array}{l}1.810 \\
(0.42) \\
\end{array}$ \\
\hline$R^{2}$ & 0.629 & 0.786 & 0.370 \\
\hline Observations & 39 & 39 & 39 \\
\hline
\end{tabular}

Notes: Absolute values of t-statistics are in parentheses. ${ }^{*}, * *$ and $* * *$ denotes significance at the 10 percent, 5 percent, and 1 percent levels, respectively. Constant included, but not reported. 
TAble 4.8 - Regressions of Productive EnTRePreneurship Scores, Controlling for Total ADHERENTS

\begin{tabular}{|c|c|c|c|c|}
\hline \multirow[b]{2}{*}{ Independent variable } & \multicolumn{4}{|c|}{ Specifications } \\
\hline & 1 & 2 & 3 & 4 \\
\hline \multicolumn{5}{|l|}{ Religiosity } \\
\hline Attendance, $\%$ & $\begin{array}{l}-0.226 \\
(1.30)\end{array}$ & - & - & - \\
\hline Prayer, \% & - & $\begin{array}{c}-0.133 \\
(0.27)\end{array}$ & - & - \\
\hline Importance, $\%$ & - & - & $\begin{array}{l}-0.362 \\
(1.53)\end{array}$ & - \\
\hline \multicolumn{5}{|l|}{ Affiliation } \\
\hline Total Adherents, $\%$ & $\begin{array}{c}-0.391^{* * *} \\
(3.51)\end{array}$ & $\begin{array}{c}-0.429^{* * *} \\
(2.91)\end{array}$ & $\begin{array}{c}-0.395^{* * *} \\
(3.53)\end{array}$ & $\begin{array}{c}-0.372^{* * * *} \\
(4.39)\end{array}$ \\
\hline Atheist/Agnostic, \% & - & - & - & $\begin{array}{l}0.499^{* * *} \\
(2.06)\end{array}$ \\
\hline \multicolumn{5}{|l|}{ Controls } \\
\hline Log GDP Per Capita & $\begin{array}{c}-10.644 \\
(0.89)\end{array}$ & $\begin{array}{l}-6.061 \\
(0.49)\end{array}$ & $\begin{array}{c}-10.975 \\
(0.90)\end{array}$ & $\begin{array}{c}-7.413 \\
(0.92)\end{array}$ \\
\hline EFNA & $\begin{array}{l}4.831^{*} \\
(1.88)\end{array}$ & $\begin{array}{l}3.797 \\
(1.45)\end{array}$ & $\begin{array}{l}5.280^{*} \\
(2.02)\end{array}$ & $\begin{array}{l}5.058^{* * *} \\
(2.44)\end{array}$ \\
\hline Pop. Density & $\begin{array}{c}0.015^{* * * *} \\
(3.04)\end{array}$ & $\begin{array}{c}0.016^{* *} \\
(2.54)\end{array}$ & $\begin{array}{c}0.015^{* * *} \\
(3.00)\end{array}$ & $\begin{array}{c}0.015^{* * *} \\
(3.94)\end{array}$ \\
\hline Median Age & $\begin{array}{c}-3.083^{* * *} \\
(3.60)\end{array}$ & $\begin{array}{c}-2.513^{* *} \\
(2.47)\end{array}$ & $\begin{array}{c}-2.892^{* * *} \\
(3.87)\end{array}$ & $\begin{array}{c}-2.753^{\text {**** }} \\
(5.54)\end{array}$ \\
\hline Bachelor's,$+ \%$ & $\begin{array}{l}0.696^{* *} \\
(2.36)\end{array}$ & $\begin{array}{c}0.847^{* *} \\
(2.33)\end{array}$ & $\begin{array}{c}0.629^{* *} \\
(2.05)\end{array}$ & $\begin{array}{c}0.629^{* * * *} \\
(3.08)\end{array}$ \\
\hline Male Pop., \% & $\begin{array}{l}-0.467 \\
(0.21)\end{array}$ & $\begin{array}{l}1.149 \\
(0.68)\end{array}$ & $\begin{array}{l}-1.045 \\
(0.44)\end{array}$ & $\begin{array}{l}-0.371 \\
(0.25)\end{array}$ \\
\hline$R^{2}$ & 0.781 & 0.771 & 0.784 & 0.796 \\
\hline Observations & 39 & 39 & 39 & 39 \\
\hline
\end{tabular}

Notes: Absolute values of t-statistics are in parentheses. ${ }^{*}, * *$, and $* * *$ denotes significance at the 10 percent, 5 percent, and 1 percent levels, respectively. Constant included, but not reported. 


\section{Chapter 5}

\section{Conclusions}

This dissertation has addressed several topics concerning the economics of entrepreneurship, institutions, and underground economies at the U.S. state level. Empirical analysis begins in Chapter 2 where I evaluate multiple causes and multiple indicators of U.S. state-level underground economies using a MIMIC model estimation technique. Here, I provide the firstever estimates of shadow economy size for the 50 U.S. states (excluding the District of Columbia) for a period spanning a little more than a decade. I demonstrate that the size of shadow economies in U.S. states are likely dependent upon the size of government, tax and social welfare burdens imposed on the citizenry, labor market regulations, and intensity of regulation enforcement aimed at identifying and deterring underground participation.

Across the states, government size has the largest, statistically significant effect on shadow economy size. A one-unit increase in the "size of government" score (which implies a higher degree of freedom from burden) leads to, on average, a 0.379 percentage point decrease in shadow economy size as a percent of state-level GDP. Taxes and charges - each as a percent of GDP - both exhibit positive and statistically significant correlations to shadow economy size (correlations are 0.206 and 0.068 , respectively). A one-unit increase in the "labor market 
freedom" score (which implies a higher degree of labor market freedom) causes a 0.069 percentage point decrease in shadow economy size, while insurance trust expenditures and protective inspection and regulation expenditures - each measured as a percent of GDP - both correlate negatively with shadow economy size (correlations are -0.200 and -0.054 , respectively) in a statistically significant way.

Based on an index constructed with MIMIC model results, I find that, on average, Delaware, Oregon, and Colorado maintain the smallest U.S. shadow economies, while West Virginia and Mississippi secure the largest as a percent of GDP. Further, the sizes of all state shadow economies appear to have decreased over the period 1997 to 2008.

There tends to be a trade-off in which high-income states foster the smallest relative shadow economies, but the highest underground GDP on a per capita basis. Perhaps this is due to relative scarcity of underground services in high-income states. If so, one might expect that underground participants command higher prices in these places. Alternatively, high levels of human capital stock may play a role in the trade-off. High income states often demonstrate higher relative levels of productivity in the formal sector; perhaps the same is true of their underground economies. Of course, this is all mere speculation at this point. A task for future research in this area will be measuring the underground economies of the U.S. states using methods (such as surveys) to construct a more reliable dataset, including measures of shadow economy population.

Chapter 3 makes use of the shadow economy estimates constructed in the previous chapter to examine the relationship between public official corruption, shadow economy size, and observed productive and unproductive entrepreneurial outcomes using a cross-section of U.S. state-level data. This study takes a closer look at William Baumol's (1990) entrepreneurial 
theory - itself an extension of Schumpeter's theory - and extends it to include an option for entrepreneurs to engage in shadow economies. How does the entrepreneur's choice to exploit the shadow economy play a role in the relationship between public official corruption and observed entrepreneurial outcomes? In a series of OLS and GMM regression analyses, I demonstrate, robustly, that shadow economy size correlates negatively (positively) and in a statistically significant way with productive (unproductive) entrepreneurship. Moreover, these results suggest both the possibility of productive entrepreneurial migration to the shadow economy, and a likely support mechanism within the shadow economy for formal sector unproductive activity.

I attempt to connect levels of public official corrupt to observed entrepreneurial outcomes by way of the shadow economy using instrumental variables. I argue that if corruption affects entrepreneurial outcomes primarily through its effect on shadow economy size, then corruption should serve as a strong and potentially valid instrument for shadow economy size.

I present evidence that corruption is a strong instrument for shadow economy size. Moreover, I do not find strong evidence that the instrument is invalid in regressions on productive, unproductive, and net entrepreneurship scores. Failure to reject validity of the corruption instrument, however, does not provide evidence of the primacy of the shadow economy. It is only, at best, suggestive of the primacy of the entrepreneurial choice between formal and informal sector participation.

This particular vein of research remains largely untouched, and leaves much room to explore several potentially important and interesting insights. Among them are the options listed in Chapter 3 related to, for example, the migration of Baumolian entrepreneurs across space; the conversion of productive activity to unproductive activity following institutional change; and a 
closer look at unlawful, unproductive activity in both the formal and informal sectors as a response to institutional change; and so on.

In Chapter 4, Andrew Young and I re-visit Baumol's (1990) conjectures on the role of institutions in determining whether entrepreneurs will channel their efforts towards wealthgenerating activities or towards zero- or negative-sum rent-seeking. We do so in the context of informal institutions. Using measures of both the belief (e.g., the frequency of prayer) and belonging (e.g., protestant affiliation) dimensions of religiosity, we find that religiosity measures tend to correlate negatively and significantly with a state's productive entrepreneurship score. However, only one measure - the percent of state's population that reports themselves as Christian adherents - passes our tests for robustness in additional regressions on productive entrepreneurship scores. We speculate that this could be because religion imposes opportunity costs in terms of time and resources that may otherwise have been devoted towards productive entrepreneurship. Alternatively (and more subjectively), religion may create psychic costs to pursuing worldly gains rather than salvation in the beyond.

The same measure of total Christian adherents, however, is robustly and positively correlated with states' unproductive entrepreneurship scores. We argue that this suggests something beyond a simple opportunity cost story. It may be that religion correlates negatively with productive entrepreneurship because its institutions increase the relative net benefits of rentseeking.

Interestingly, we also find that the percent of a state's population that report themselves as atheist and/or agnostic is positively and significantly related to productive entrepreneurship (even when controlling for total Christian adherents) but has no significant relationship with unproductive entrepreneurship. 
It is plausible that productive entrepreneurial activities and religious activities are largely substitutes while unproductive entrepreneurial activities are complimentary to religious activities. Independent of the depth of adherent's beliefs, churches or other religious forums may function as special interest groups and work through political processes to capture rents for their members. The time and resources used in these religious activities would not be available for wealth-generating ones, leading to substitution away from productive entrepreneurial activities. This, of course, all amounts to mere conjectures, presently. Again, it hopefully represents fruitful avenues for further study. 


\section{References}

Alderslade, Jamie, John Talmage, and Yusef Freeman (2006). "Measuring the Informal Economy: One Neighborhood at a Time," A discussion paper prepared for The Brooking Institution Metropolitan Policy Program.

Ashby, Nathan, Avilia Bueno, and Fred McMahon; with Deborah Martinez (2011). Economic Freedom of North America 2011, Fraser Institute.

Avnimelech, Gil, Yaron Zelekha, and Eyal Sarabi (2011). "The Effect of Corruption on Entrepreneurship," Working Paper prepared for presentation at the DRUID 2011.

Audretsch, David, Max Keilbach, and Erik Lehman (2006), Entrepreneurship and Economic Growth, New York: Oxford University Press.

Audretsch, David, Werner Boente, and Jagannadha Tamvada (2007), "Religion and Entrepreneurship," Working Paper.

Barrett, Paul. (2007). "Structural Equation Modelling: Adjudging Model Fit," Personality and Individual Difference, 42: 815-824.

Barro, Robert, and Rachel McCleary (2003), "Religion and Economic Growth across Countries," American Sociological Review, 68 (3), 760-781.

Barro, Robert, and Rachel McCleary (2005), “Which Countries Have State Religions?” The Quarterly Journal of Economics, 120 (4), 1331-1370.

Baumol, William (1990), "Entrepreneurship: Productive, Unproductive and Destructive," Journal of Political Economy, 98 (5), 893-921.

Baumol, William (2002), Free Market Innovation Machine: Analyzing the Growth Miracle of Capitalism, Princeton: Princeton University Press.

Baumol, William, Robert Litan, and Carl Schramm. (2007), Good Capitalism, Bad Capitalism, and the Economics of Growth and Prosperity, Yale: Yale University Press. 
Bollen, Kenneth (1989). Structural Equations with Latent Variables, New York: Wiley.

Browne M., and R. Cudeck (1993). "Alternative Ways of Assessing Model Fit," in K. Bollen and J. Long (Eds.) Testing Structural Equations, 136-162: Newbury Park, CA: Sage.

Buehn, Andreas, and Friedrich Schneider (2012). "Shadow Economies Around the World: Novel Insights, Accepted Knowledge, and New Estimates," International Tax and Public Finance, 19: 139-171.

Buehn, Andreas (2011), "The Shadow Economy in German Regions: An Empirical Assessment," German Economic Review, 13(3): 275-290.

Bruesch, Trevor (2005). "Estimating the Underground Economy Using MIMIC Models," Working Paper.

Campbell, Noel, Alex Fayman, and Kirk Heriot (2010). "Including U.S. State Government Regulation in the Economic Freedom of North America Index," The Journal of Private Enterprise, 25(2): 165-186.

Carswell, Peter, and Deborah Rolland. (2007). "Religion and Entrepreneurship in New Zealand," Journal of Enterprising Communities: People and Places in the Global Economy, 1 (2), 162-174.

Chaudhari, Kausik, Friedrich Schneider, and Sumana Chattopadhyay (2006). "The Size and Development of the Shadow Economy: An Empirical Investigation from States of India," Journal of Development Economics, 80: 428-443.

Dell'Anno, Roberto, and Offiong Helen Solomon (2008). "Shadow Economy and Unemployment Rate in USA: Is There A Structural Relationship? An Empirical Analysis," Applied Economics, 40: 2537-2555.

Dell'Anno, Roberto, and Friedrich Schneider (2006). "Estimating the Underground Economy by Using MIMIC Models: A Response to T. Breusch's Critique,” Working Paper.

deSoto, Hernando (1989). The Other Path: Economic Answers to Terrorism, Basic Books: New York, NY.

deSoto, Hernando (2000). The Mystery of Capital: Why Capitalism Triumphs in the West and Fails Everywhere Else, Basis Books: New York, NY.

Dodd, Sarah Drakopoulou and George Gotsis. (2007). "The Interrelationships between Entrepreneurship and Religion," International Journal of Entrepreneurship and Innovation, 8 (2), 93-104.

Dreher, Axel, and Friedrich Schneider (2010), "Corruption and the Shadow Economy: An Empirical Analysis," Public Choice, 144: 215-238 
Dreher, Axel, Christos Kosogiannis, and Steve McCorrston (2009), "How Do Institutions Affect Corruption and the Shadow Economy?," International Tax and Public Finance, 16: 773-796.

Estrin, Saul, and Tomasz Mickiewicz (2012). "Shadow Economy and Entrepreneurial Entry," Review of Development Economics, 16(4): 559-578.

Feld, Lars, and Friedrich Schneider (2010). "Survey on the Shadow Economy and Undeclared Earnings in OECD Countries," German Economic Review, 11(2): 109-149.

Frey, Bruno S., and Hannelore Weck-Hanneman (1984). "The Hidden Economy as an 'Unobserved' Variable,” European Economic Review, 26: 33-53.

Friedman, Eric, Simon Johnson, Daniel Kaufmann, and Pablo Zoido-Lobaton (2000), "Dodging the Grabbing Hand: the Determinants of Unofficial Activity in 69 Countries," Journal of Public Economics, 76: 459-493.

Glaeser, Edward L. (2007). "Entrepreneurship and the City," NBER Working Paper No. 13551 (http://www.nber.org/papers/w13551).

Hall, Joshua C. and Sobel, Russell, S. (2008). "Institutions, Entrepreneurship, and Regional Differences in Economic Growth," Southern Journal of Entrepreneurship. 1 (1), 69-96.

Hamilton, Barton. (2000). "Does Entrepreneurship Pay? An Empirical Analysis of the Returns to Self-Employment," Journal of Political Economy. 108 (3), 604-631.

Harris, Sam. (2004). The End of Faith: Religion, Terror, and the Future of Reason, New York,N.Y.: W.W. Norton \& Company, Inc.

Hurst, Erik G., and Benjamin Wild Pugsley. (2011). "What do Small Businesses Do?" Brookings Papers on Economic Activity. 43 (2), 73-142.

Iannaccone, Laurence R. (1998). "Introduction to the Economics of Religion," Journal of Economic Literature. 36 (September), 1465-1496.

Johnson, Simon, Daniel Kaufmann, and Pablo Zoido-Lobaton (1998a), "Regulatory Discretion and the Unofficial Economy," American Economic Review, 88: 387-392.

Johnson, Simon, Daniel Kaufmann, and Pablo Zoido-Lobaton (1998b), "Corruption, Public Finances, and the Unofficial Economy,” World Bank Policy Research Working Paper.

Johnson, Simon, Daniel Kaufmann, and Andrei Shleifer (1997), “The Unofficial Economy in Transition," The Brookings Papers on Economic Activity, 2(28): 159-240.

Jovanovic, Boyan (1982). "Selection and the Evolution of Industry," Econometrica, 50(3): 649-670. 
Karabegović, Amela., Fred McMahon, and Christy G. Black. (2006). Economic Freedom of North America: 2006 Annual Report. Vancouver, Fraser Institute.

Katsios, Stavros (2006) "The Shadow Economy and Corruption in Greece," South-Eastern Europe Journal of Economics, 1: 61-80.

Kaufmann, Daniel, and Aleksander Kaliberda (1996).'Integrating the Unofficial Economy into the Dynamics of Post-Socialist Economies," published in Economic Transition in Russia and the New States of Eurasia: v.8, M.E. Sharpe, Inc.: New York, NY.

Kirzner, Israel (1973). Competition and Entrepreneurship. Chicago: University of Chicago Press.

Kirzner, Israel (1979). Perception, Opportunity, and Profit. Chicago: University of Chicago Press.

Knight, Frank (1921). Risk, Uncertainty, and Profit. Boston: Houghton Mifflin.

Kucera, David and Leanne Roncolato (2008). "Informal Employment: Two Contested Policy Issues," International Labor Review, 147 (4): 321-348.

Kuran, Timur. (2011). The Long Divergence: How Islamic Law Held Back the Middle East. [Kindle Edition] Princeton: Princeton University Press.

Lacko, Maria (1998). "The Hidden Economies of Visegrad Countries in International Comparison: A Household Electricity Approach," in Hungary: Towards a Market Economy, Cambridge University Press.

Lacko, Maria (1999). "Electricity Intensity and the Unrecorded Economy in Post-Socialist Countries," in Underground Economies in Transition, Ashgate Publishing Ltd.

Lacko, Maria (2000a). "Do Power Consumption Data Tell the Story?: Electricity Intensity and Hidden Economy in Post-Socialist Countries," in Planning, Shortage, and Transformation: Essays in Honor of Janos Kornai, MIT Press.

Lacko, Maria (2000b). "Hidden Economy: an Unknown Quantity?: Comparative Analysis of Hidden Economies in Transition Countries, 1989-1995," Economies in Transition, 8(1): 117-149.

Leeson, Peter, and Russell Sobel (2008), "Weathering Corruption," Journal of Law and Economics, 51: 667-681.

Levenson, Alec, and William Maloney (1996). Modeling the Informal Sector: Theory and Empirical Evidence from Mexico, Mimeo, University of Illinois and the Milken Institute. 
MacCallum, Robert, Michael Browne, and Hazuki Sugawara (1996). "Power Analysis and Determination of Sample Size for Covariance Structure Modeling," Psychological Methods, 1: 130-149.

Maloney, William (2004). “Informality Revisited,” World Development, 32(7): 1159-1178.

McCleary, Rachel, and Robert Barro. (2006), "Religion and Political Economy in an International Panel," Journal for the Scientific Study of Religion, 45 (2), 149-175.

McCleary, Rachel. (2008), "Religion and Economic Development,” PolicyReview, No. 148, Hoover Institution.

Moskowitz, Tobias J., and Annette Vissing Jørgensen. (2002). "The Returns to Entrepreneurial Investment: A Private Equity Premium Puzzle?” American Economic Review, 92 (4), 745-778.

Mulligan, Casey, and Xavier Sala-i-martin (1992). "U.S. Money Demand: Surprising Cross-sectional Estimates," Brookings Papers on Economic Activity, 2.

Neuwirth, Robert (2011), Stealth of Nations: The Global Rise of the Informal Economy, Random House: New York, NY.

North, Douglass C. (1990). Institutions, Institutional Change and Economic Performance. Cambridge: Cambridge University Press.

North, Douglass C. (1991). “Institutions,” Journal of Economic Perspectives, 5(1): 97-112.

Radmard, Hossein. (2012). "Religion and Entrepreneurship: A County-Level Analysis," Unpublished Manuscript.

Rissman, Ellen. (2003). "Self-Employment as an Alternative to Unemployment," Federal Reserve Bank of Chicago Working Paper No. WP-03-34.

Samulesson, Kurt. (1961). Religion and Economic Action. Stockholm: Scandinavian University Books.

Schneider, Friedrich (2012). "The Shadow Economy and Work in the Shadow: What do We (Not) Know?," IZA Discussion Paper No. 6423

Schneider, Friedrich, Andreas Buehn, and Claudio Montenegro (2010). "New Estimates for the Shadow Economies all over the World," International Economic Journal, 24: 443-461.

Schneider, Friedrich (2010a). "The Influence of Public Institutions on the Shadow Economy," The Review of Law and Economics, 6(3): 441-468. 
Schneider, Friedrich (2010b). "The Influence of the Economic Crisis on the Underground Economy in Germany and the other OECD-countries in 2010: A (Further) Increase," Working Paper.

Schneider, Friedrich, and Andreas Buehn (2009). "Shadow Economies and Corruption All Over the World: Revised Estimates for 120 Countries," Economics, 2: 1-53.

Schneider, Friedrich (2006), "Shadow Economies and Corruption all Over the World: What Do We Really Know?,” Working Paper.

Schneider, Friedrich and Dominik Enste (2000). "Shadow Economies: Sizes, Causes, and Consequences," Journal of Economic Literature, 38: 77-114.

Schumpeter, Joseph (1921 [1934]). The Theory of Economic Development: An Inquiry into Profits, Capital, Credit, Interest, and the Business Cycle. Cambridge: Harvard University Press.

Schumpeter, Joseph (1942). Capitalism, Socialism, and Democracy. New York: Harper and Row.

Sennholz, Hans (1984). The Underground Economy, Ludwig von Mises Institute: Auburn, AL.

Smith, Adam (1776 [2003]). The Wealth of Nations. New York: Bantum Dell

Sobel, Russell (2008). "Testing Baumol: Institutional Quality and the Productivity of Entrepreneurship," Journal of Business Venturing 23 (6), 641-655.

Sobel, Russell, and Thomas Garrett (2002). "On the Measurement of Rent Seeking and its Social Opportunity Cost," Public Choice, 112(1-2): 115-136.

Steiger, James, and J. Lind (1980). "Statistically-based Tests for the Number of Common Factors," Paper presented at the annual meeting of the Psychometric Society, Iowa City, IA.

Tanzi, Vito (1999). "Uses and Abuses of Estimates of the Underground Economy," The Economic Journal, 109: 338-347.

Tawney, Richard H. (2012 [1922]). Religion and the Rise of Capitalism. [Kindle Edition] Hesperides Press.

Taylor, Humphrey, David Krane, and Amy Cottreau (2002-08, 2010). "State Liability Systems Ranking Study," United States Chamber of Commerce. 
Tonoyan, Vartuhi, Robert Strohmeyer, Mohsin Habib, and Manfred Perlitz (2010). “Corruption and Entrepreneurship: How Formal and Informal Institutions Shape Small Firm Behavior in Transition and Mature Market Economies," Entrepreneurship Theory and Practice, 34(5): 803-831

Torgler, Benno, Friedrich Schneider, and Alison Macinytre (2011), "Shadow Economy, Voice and Accountability, and Corruption," in Friedrich Schneider (ed.) Handbook on the Shadow Economy, Edward Elgar: Cheltenham, UK.

Weber, M., (Peter Baehr, and Gordon Wells) (2002 [1905]). The Protestant Ethic and the Spirit of Capitalism, London: Penguin Books.

Wiseman, Travis, and Andrew T. Young (2012a). "Economic Freedom, Entrepreneurship, \& Income Levels: Some US State-Level Empirics,” American Journal of Entrepreneurship, (forthcoming).

Wiseman, Travis, and Andrew T. Young (2012b). "Religion: Productive or Unproductive," Working Paper.

Wiseman, Travis (2012). "U.S. Shadow Economies: A State-Level Study,” Working Paper.

Zacharakis, A., W. Bygrave, and D. Shepherd (2000). Global Entrepreneurship Monitor: National Entrepreneurship Assessment, United States of America, Kansas City, Kauffman Center for Entrepreneurial Leadership. 


\section{Travis Wiseman}

Department of Economics

College of Business and Economics

West Virginia University

P.O. Box 6025
Email: travis.wiseman@mail.wvu.edu

Phone: 1.540 .223 .0456

Website: www.traviswiseman.com

Updated: March 2013

Education

Ph.D., Economics, West Virginia University, April 2013

Dissertation Title: Entrepreneurship, Institutions, and the Informal Economy

Committee: Andrew Young (Chair), Roger Congleton, Brian Cushing, Russell Sobel, and William Trumbull

B.S., Economics, West Virginia University, May 2008

\section{Areas of Applied Research}

Development Economics, Public Economics, Entrepreneurship, Shadow Economy, and Institutions

\section{Papers Published and Under Review}

"Economic Freedom, Entrepreneurship, \& Income Levels: Some U.S. State-level Empirics" (with Andrew Young), American Journal of Entrepreneurship (forthcoming)

"Are the Effects of Foreign Aid Non-Rivalrous for Donor Country Citizens?" (with Andrew Young), Manuscript under review at the Review of International Economics.

"Religion: Productive or Unproductive?" (with Andrew Young), Manuscript under review at the Journal of Institutional Economics.

"Changing Perceptions of Maturity Mismatch in the U.S. Banking System: Evidence from Equity Markets" (with Andrew Young and Thomas Hogan), Manuscript under review at the Southern Economic Journal (with revision request)

\section{Working Papers}

"U.S. Shadow Economies: A State-level Study"

"Entrepreneurship, Corruption, and the Size of U.S. Underground Economies"

"Homo-innovaticus: Institutions and Innovative Potential Around the World" 
Awards

Association of Private Enterprise Education Young Scholars Award, 2010, 2011.

West Virginia University, College of Business and Economics Summer Research Grant, 2010.

Institute for Humane Studies Fellowship, with title: Bernard Marcus Fellow, 2011-2012.

European Social Fund Doctoral Studies and Internationalisation Programme, DoRa Scholarship, 2012 (included a visiting research position at the University of Tartu, Estonia).

Charles G. Koch Doctoral Fellowship, 2012-2013.

Vickers Doctoral Student Teaching Award, 2012.

Kendrick Business and Economics Graduate Studies Scholarship, with title: Kendrick Scholar, 2012-2013

\section{Professional Activities}

Research Positions

Graduate Research Assistant to Andrew Young, West Virginia University, Fall 2009-Spring 2011

Visiting Ph.D. Student, University of Tartu, Estonia, Supervisor: Viktor Trasberg, Fall 2012

Courses Taught

Comparative Economic Systems (Econ 454), West Virginia University, Summer 2011

(Honors) Microeconomic Principles (Econ 201), West Virginia University, Fall 2011

Microeconomic Principles (Econ 201; large section), West Virginia University, Spring 2012

Comparative Economic Systems (Econ 454), West Virginia University, Summer 2012

Conference Presentations

Association of Private Enterprise Education Meetings, Las Vegas, NV, April 2010

Southern Economic Association Meetings, Atlanta, GA, November 2010

Association of Private Enterprise Education Meetings, Nassau, Bahamas, April 2011

Second World Congress of the Public Choice Societies Meetings, Miami, FL, March 2012

Southern Economic Association Meetings, New Orleans, LA, November 2012

Association of Private Enterprise Education Meetings, Maui, HI, April 2013 
Invited Seminar Presentations

The Economic System, West Virginia University, College of Business and Economics, Morgantown, WV, October 31 - November 4, 2011 (two lectures)

Memberships

American Economic Association

Association of Private Enterprise Education

Public Choice Society

Southern Economic Association 